Florida International University

FIU Digital Commons

FIU Electronic Theses and Dissertations

University Graduate School

3-19-2020

\title{
Neoliberalism and Monopoly in the Motion Picture Industry
}

Michael S. Wartenbe

Florida International University, mwart001@fiu.edu

Follow this and additional works at: https://digitalcommons.fiu.edu/etd

Part of the American Politics Commons, International Economics Commons, International Relations

Commons, and the Political Economy Commons

\section{Recommended Citation}

Wartenbe, Michael S., "Neoliberalism and Monopoly in the Motion Picture Industry" (2020). FIU Electronic Theses and Dissertations. 4417.

https://digitalcommons.fiu.edu/etd/4417

This work is brought to you for free and open access by the University Graduate School at FIU Digital Commons. It has been accepted for inclusion in FIU Electronic Theses and Dissertations by an authorized administrator of FIU Digital Commons. For more information, please contact dcc@fiu.edu. 


\section{FLORIDA INTERNATIONAL UNIVERSITY}

Miami, Florida

NEOLIBERALISM AND MONOPOLY IN THE

MOTION PICTURE INDUSTRY

A dissertation submitted in partial fulfillment

of the requirements for the degree of

DOCTOR OF PHILOSOPHY

in

INTERNATIONAL RELATIONS

by

Michael Wartenbe

2020 
To: Dean John F. Stack, Jr.

Steven J. Green School of International \& Public Affairs

This dissertation, written by Michael Wartenbe, and entitled Neoliberalism and Monopoly in the Motion Picture Industry, having been approved in respect to style and intellectual content, is referred to you for judgment.

We have read this dissertation and recommend that it be approved.

$\begin{array}{r}\text { Gail Hollander } \\ \hline \text { Jin Zeng } \\ \hline \text { Clement Fatovic } \\ \hline \text { Ronald Cox, Major Professor }\end{array}$

Date of Defense: March 19, 2020

This dissertation of Michael Wartenbe is approved.

Dean John F. Stack, Jr.

Steven J. Green School of International \& Public Affairs

Andrés G. Gil

Vice President for Research and Economic Development and Dean of the University Graduate School

Florida International University, 2020 


\author{
ABSTRACT OF THE DISSERTATION \\ NEOLIBERALISM AND MONOPOLY IN THE \\ MOTION PICTURE INDUSTRY \\ by \\ Michael Wartenbe \\ Florida International University, 2020 \\ Miami, Florida \\ Professor Ronald Cox, Major Professor
}

Monopolies and industry concentration have returned in our time, as did the ramifications in the globalized political economy. One of the most impactful in our daily lives are the Mass Media Conglomerates who not only own the majority of film, television, and news we access, but increasingly control the means of accessing it, from cable to digital. While many are familiar with these corporations via their services and products, less known by the public are their political operations and close cooperation with Washington. This is due to the lack of holistic analysis of the industry and cooperation in the media oligopoly. Especially lacking is the focus on trade associations in the political process.

As such, this dissertation analyzes the role of the prominent trade association for the film industry - the Motion Picture Association of America (MPAA). The MPAA was formed in the early days of Hollywood's film dominance, and today is one of the most prominent and notorious trade associations in promoting neoliberal development. These changes include transnationalized production and distribution, Intellectual Property Rights extensions, and invasive trade agreements to name a few. The influence and power to do so goes beyond lobbying, by instrumentalizing their industry, incorporating state bureaucracies, and developing an international structure that enhances corporate political power. The results have been an ever-growing consolidation that branches into related sectors and industries of communication and technology. With this such trade associations like the MPAA become more 
representative and hold more political leverage, which is increasingly used on the global arena and impacting the foreign and domestic policy of many states far beyond Hollywood. 


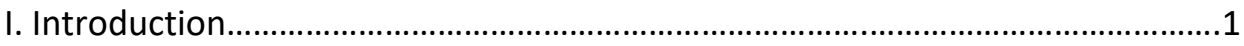

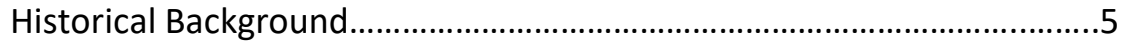

Neoliberalism..........................................................................................

The Evolution of the Neoliberal Era: Contemporary Scholarship............17

Internationalization, Intellectual Property, and Corporate Power...........22

Associationalism.......................................................................................2

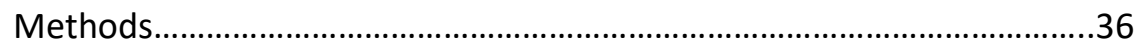

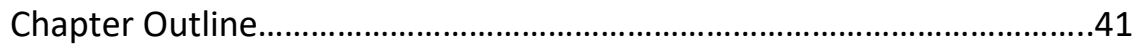

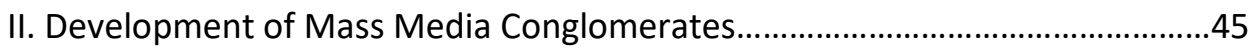

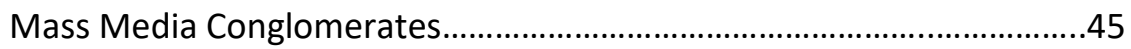

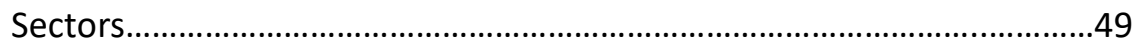

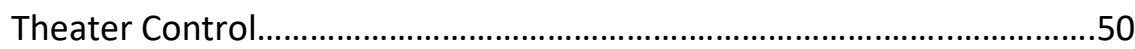

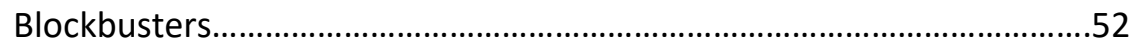

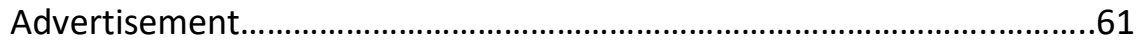

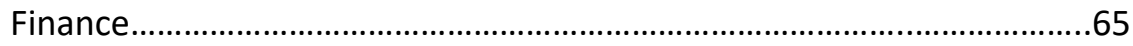

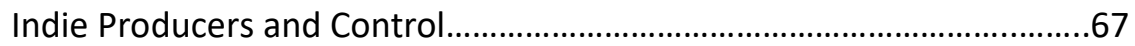

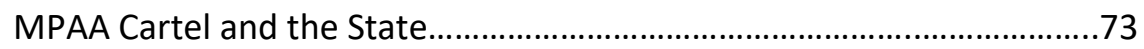

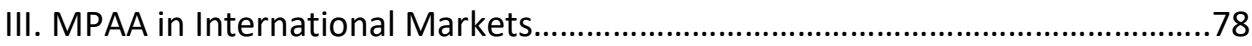

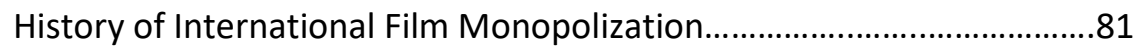

The Motion Picture Export Association......................................................83

Internationalization and Domestic Politics..............................................87

The Film Oligopoly under Neoliberalism....................................................91

Special 301 - Expanding State Partnership.............................................94

Integration into the Global Film Structure.............................................99

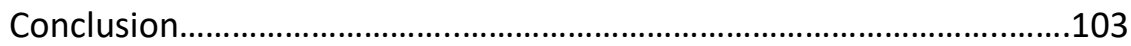

IV. Corporations, Associations, and the State: The International Subsidy

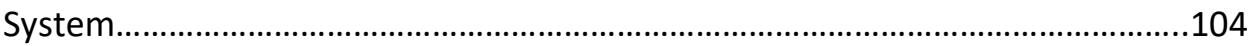

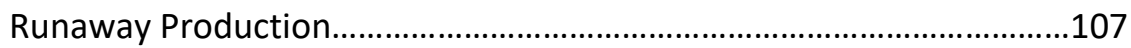

International Subsidies: Canada and Europe.........................................111

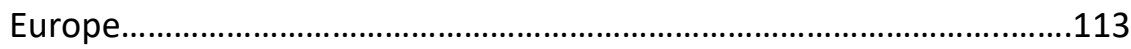

Expansion of Subsidies: American States..............................................116

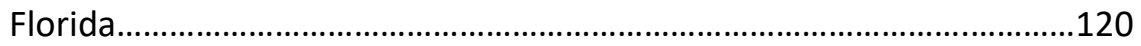

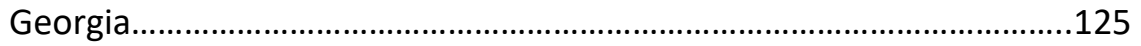

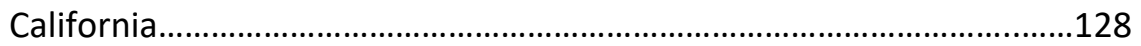

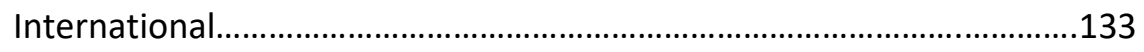

Consolidation of a Global System............................................................136

Local Incentives to a Neoliberal Subsidy System....................................140 


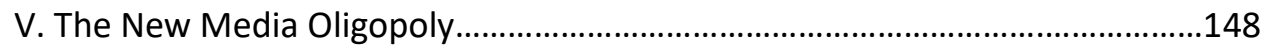

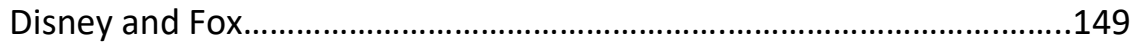

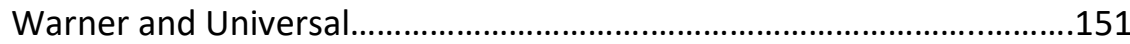

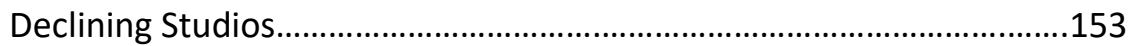

Changes to Industry Competition...........................................................156

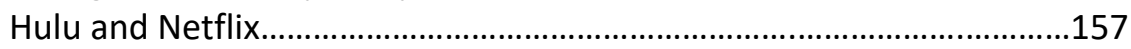

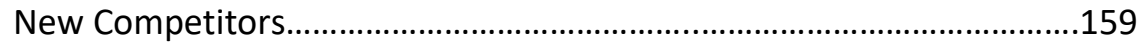

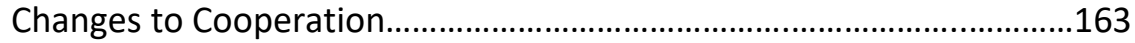

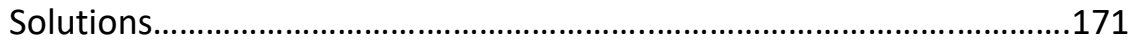

List of

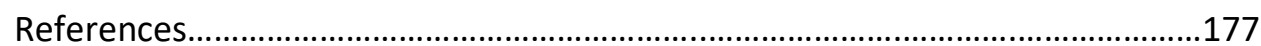

VITA 


\section{LIST OF FIGURES}

FIGURE

PAGE

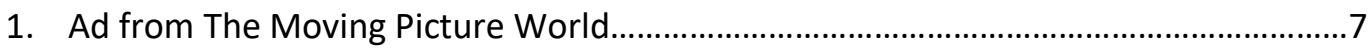

2. Aspects of Motion Picture Eras.................................................................................12

3. Control Pyramid Graphic...........................................................................................

4. Overlapping Trade Association Example: FACT, IIPA, and DCA......................................36

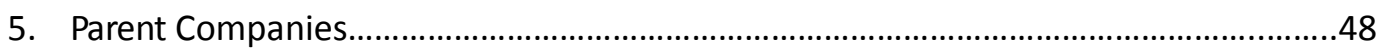

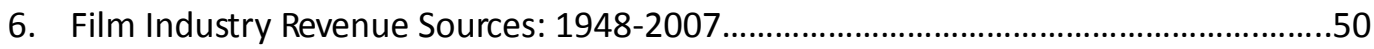

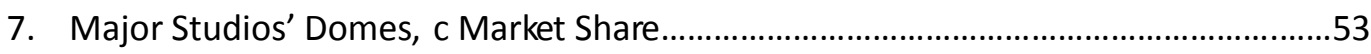

8. Domestic and International Box Office Revenue for Major Studios...............................58

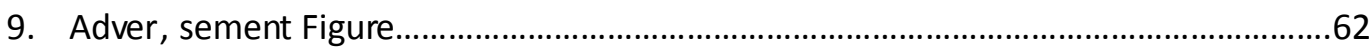

10. Domes , c Box Office Share for MPAA Films....................................................................64

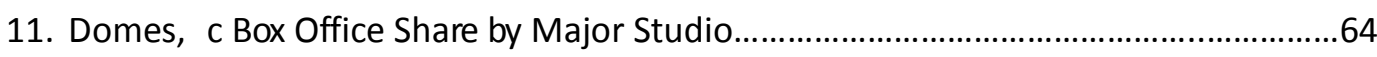

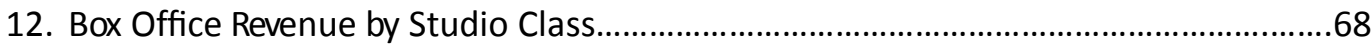

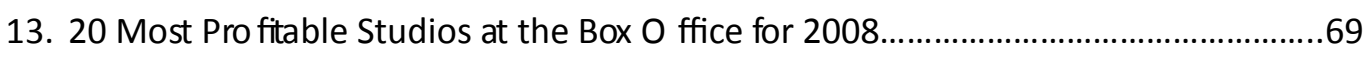

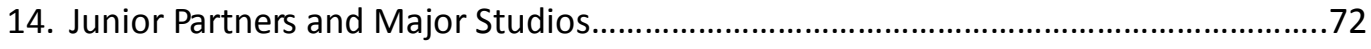

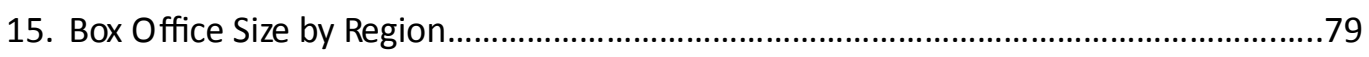

16. Major Studios share of Box Office, La, n America..........................................................8

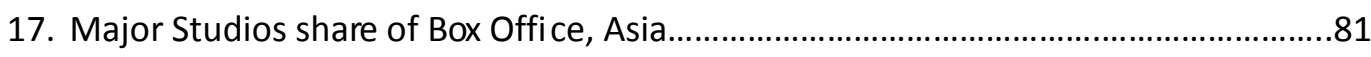

18. Major Studios share of Box Office, Europe...................................................................

19. Number of Theaters globally and share of American Films, 1949..............................86

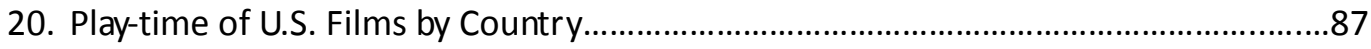

21. Theatrical Releases versus Film Admissions in EU, 2005-2013..................................102

22. Number of Incentive Programs and Funds...............................................................116

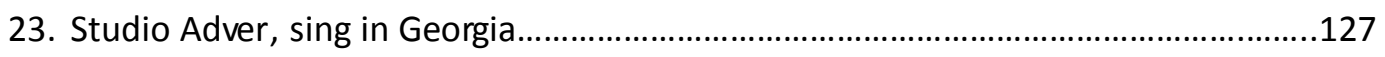

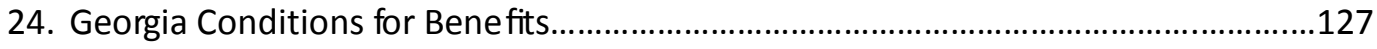

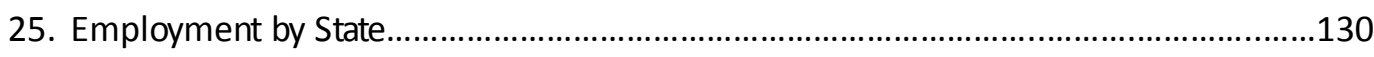

26. Largest Box o ffce Revenue Film Produc on Locations.................................................133 
27. Leading International Subsidies..

28. Domes, c Box Off ice Share by Major Studio

29. Box Offi ce Share by Year, Disney and Fox.

30. Box Office Share by Year, Warner and Universal.

31. Box Office Share by Year, Sony..... .153

32. Box Office Share by Year, Viacom. .154

33. Box Offi ce Share by Year, Lionsgate. .155

34. Video On Demand Users by Platform. .162

35. Spending on Production and Acquisi, on of New Content... .163

36. "FACT" Anti-Piracy Network. .165

37. FACT Members as of 2015. 168

38. Box Office Size by Region. .175 


\section{Introduction}

In our time, monopoly and oligopoly have become the norm in many industries. Massive corporations dominate headlines, economics, and even politics. In many industrial sectors of contemporary capitalism, we can count nearly $100 \%$ of an industry on one hand. Yet, even in this normalization of monopolies and duopolies, a few industries stand out even in that concentration. Computer technology and pharmaceuticals are among them, but film and media are especially notable, not only due to their necessarily public image, but because of the degree of collusion and partnership within the industry. This level of concentration is such that Hollywood is nearly synonymous with the Major Studios, which together comprise the Motion Picture Association of America (MPAA): Walt Disney, Universal, Paramount, Sony, Warner Bros, and, for the majority of its history, 20th Century Fox. These Major Studios are so ingrained in our understanding of film that any producer outside of these majors is automatically "independent". They have long been an important factor in the culture and entertainment of effectively all Americans. Indeed, this is true for an incredibly large portion of the world.

These companies have been able to dominate not only their domestic market, but the global market for film and related media. However, like most other oligopolistic industries, the Major Studios could not have won their leadership position without the help of governments-especially the U.S. government, with whom Hollywood has a very close relationship. While capitalism has a general propensity toward high levels of concentration, corporations have also used their political power and influence to facilitate the domination of global markets. The cohesive and cartel-like MPAA has long been the political arm of the Major Studios, utilizing modern tactics and old strategies to develop 
the international media oligopoly we have today. These studios are Warner Bros., Universal, Sony, Paramount, Walt Disney Studios, and until recently Fox.

This dissertation will look into the connection and integration of monopoly-like behavior and power of these corporations, who remain competitors with one another in the market. This will answer the question as to how monopolistic is the film industry, despite being structured in as a clear oligopoly. This market competition is aligned with political and institutional cooperation, especially around the MPAA trade association. This organized and exclusive process allows for behavior similar to a cartel, both in the market and politically, without contradicting antitrust regulation. As a result, these corporations are able to increase their economic and political power and influence much further than they would individually.

As such, I plan to show the relationship between political influence and monopolization. In doing so, I will juxtapose historical strategies of control within the film industry with the modernized tactics that increase the leverage and power of the oligopoly, both internationally and within the industry. This will be done within the context of a critical framework of capitalism's structure, which can inherently lead to concentration of economic power, but the focus will be on the instrumentalization of the state by the Major Media Corporations. In doing so, I will contribute to the scholarly literature in several ways. First, I will connect the literature on corporate political power with the literature on film industry monopolization, which is lacking this theoretical framework. Second, I will contribute to the literature on cartels and corporate collusion as tools used by corporations to limit outside competition, rather than solely for price setting. Third, I will contribute to literature focusing on the instrumentalization of the state, as opposed to structural explanations for neoliberal policy. Fourth, I will contribute to literature connecting neoliberalism to the transnationalization of corporations. Finally, 
this dissertation will expand the conception of corporate power beyond lobbying and regulation to analyze effects on the industry, product, society, politics, international relations, and the global economic order.

Much literature examining the monopolization and domination of the major studios that make up the MPAA tend to focus on only two common aspects of neoliberalism: technology and ideology (Holt, 2011; May, 2000; Prince, 2000; Wasko, 1994). While undoubtedly important variables, the overemphasis on these aspects simplifies the neoliberal shift as well as the effect of state and global neoliberalization on the film industry and vice-versa. This is particularly problematic as it under-analyzes the political activities of the Major Studios and their association in the process. Especially, the focus on technology in explaining the process of monopolization eliminates an analysis of both agency and structure in favor of both a natural and inevitable evolution of society. As such, this limitation is itself highly political as it defends any shift by claiming it is beyond politics and thus simply a process to understand rather than affect. This technological evolution explanation has been used in defense of many industry monopolizations as it carries the same conclusions as a neoliberal analysis. As such, any study utilizing neoliberal epistemology to study a neoliberal process will garner no new details. This has been especially evident with the financial sector, where technology was used to explain the growth of banks, high market share, and risky products. The creation of new mathematical formulas and financial products was a natural process and a natural conclusion to the industry. This naturalization defense of the process obviously removes both the important political factors involved as well as the actual economic components and outcomes.

By focusing on the political and economic power of the Major Studios, this dissertation will contribute to a better understanding of both the film industry and the 
general shift toward neoliberalism. Although the film industry may be seen as a relatively minor actor, especially when compared to larger industries with greater revenue and capital, it is important in showing how neoliberalism developed as a process, especially given the interplay between powerful corporate actors, market forces and state policy. The monopolization that started in the 1980 s and continues today is not solely the result of technology, ideology or individual agents, but instead has been driven by a broad base of collusion and affiliations of corporations, industries, and governments. The political activities of the Major Studios can be seen both individually and within larger lobbying groups such as the Motion Picture Association of America (MPAA) and associations they have been part of, such as the International Intellectual Property Alliance (IIPA), and the Federation Against Copyright Theft (FACT). Their own activities to increase market share and protect profits is thus a key component of the global spread of neoliberal policy.

In the remainder of this chapter I will first introduce the film industry by examining the history of Major Studio control, which will reveal a strong consistency in the oligopoly's strategy up to today. This will be followed by a transition discussing the new tactics associated with the origins of neoliberalism during the 1980s. Here I will analyze in more detail the limitations of existing scholarly literature in addressing and explaining the power of the film oligopoly. I will then examine broader topics of corporate power: intellectual property, internationalization, and neoliberalism. This is to both inform the topic of the film oligopoly, but also reveal what lessons can be applied generally from such an analysis. Finally, I will analyze the theoretical conceptions of cartel power to show how an oligopoly controls and shapes an industry, both of which are too rarely deployed in contemporary scholarly accounts. I will conclude with an overview of the methods used in this dissertation and will provide an outline of the remaining chapters. 


\section{Historical Background}

Starting in the late $19^{\text {th }}$ century, film and movies were a relatively new product and industry. Following traditions of early projection technology, the rudimentary film industry focused on the novelty of the technology exhibited by traveling showmen (Bakker, 2003). As situated theaters, nickelodeons (early, cheap theaters), and habitual audiences were formed the industry structure that was established bore more resemblance to what we see today. The industry was divided into three sectors:

Production was the actual writing, filming, and editing of scenes; Distribution was the movement and allocation of film to theaters; and Exhibition was when the film was shown to an audience. In theory these were separated sectors, but in practice distribution was usually performed by the largest production companies, which would give them leverage in dealing with the remaining actors. ${ }^{1}$ The birth of the industry also occurred as intellectual property--patents and copyright--became standardized in law in Western, capitalist states (Johns, 2009; Boldrin and Levine, 2008). As a result, the leverage coming from leading producers and distributors were exponentially compounded by their aggressive and overbearingly litigious use of patents, which helped develop a naturally close relationship with the legal systems and governments.

Due to this dependence on intellectual property, the industry quite quickly suffered from vertical and horizontal monopolization, a common problem of the unregulated capitalism of the time. As nickelodeons became dependent on distributors,

\footnotetext{
${ }^{1}$ While this is impactful for smaller producers who need their larger competitors to distribute for them, it was also a major issue for exhibitors. The Nickelodeon owners and projectionists were commonly from blue-collar class, while producers had more education and money (Seabury, 1926). As will be seen, producers had a much easier time consolidating their influence and colluding together through cartels, while Nickelodeons and projectionists were divided enough to never develop a counterbalance.
} 
and small production companies became dependent on camera manufacturers, this vertical monopolization (controlling multiple sectors) began butting heads with horizontal competition (competition within a sector). In this system, producers could not anticipate the ways various lawsuits and camera patent settlements would go. This problem was especially compounded as the leading camera manufacturers were also the leading film producers. Using an "infringing" camera that potentially used a competitor's patent could lead to a lawsuit not only over its use in production, but also for the distribution and exhibition of a film filmed with it. Infamously, it was Thomas Edison's Studio that was especially problematic due to holding early camera patents, being especially litigious even compared to other producers, and willing to cause confusion and misinformation in the industry, such as placing ads that suggest his patent is enforceable despite having lost the argument in court (see Edison ad). Because of the precarious and difficult position of all involved in such a cutthroat environment, there was much support for partnership at the top for stability in the industry. 
1. Ad from The Moving Picture World (1907, pp. 34). This is after Edison lost a suit, but still trying to stir up confusion over the use of competitor's Cameras.

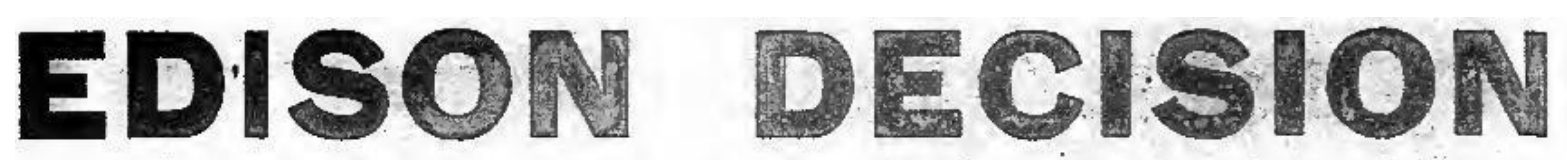

In the suit of Thomas A. Edison against the American Mutoscope and Biograph Company, the United States Circuit Court of Appeals has sustained the Edison Patent, and held that all apparatus in which the film is operated by a sprocket or similar movement like that of the WARWICR camera, which was used by the Biograph Company, infringes the Edison patent. The apparatus used or making Murtoscope slot machine pictures, which operates on a different orinciple, was held not to infringe the patent.

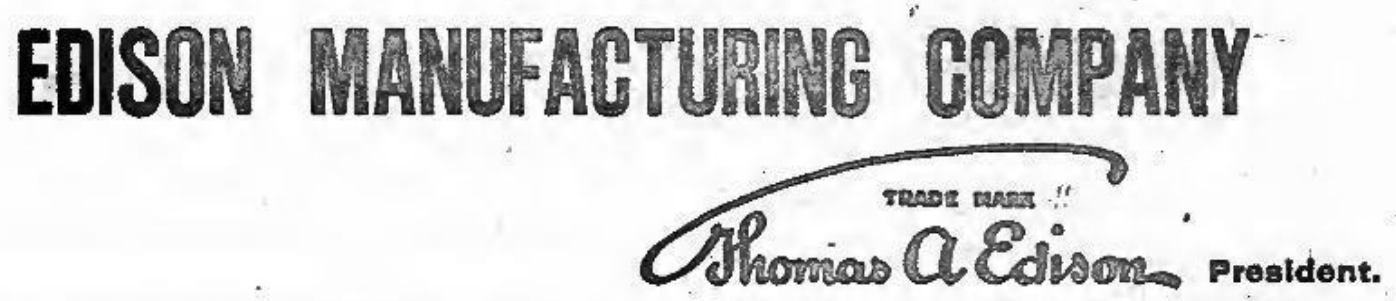

As a result, the leading producers and distributors combined to form a Trust known as The Motion Picture Patents Company (MPPC) in 1908. Also known as Edison's Trust, the MPPC was a means to end the fierce and volatile competition, as entrepreneurs experimented with ways to utilize this new technology in its early years. By uniting the largest producers and distributors, patent use became clearer and more stable. But having such a monopoly inevitably began limiting the capacity of new entrants into the industry. In addition to possessing a horizontal monopoly, this domination was helped along by Edison's leadership which continued the aggressive strategy of rigorous protection of patents (hence "Patents Company" in the name). Now 
with a broader and strengthened set of patents in the Trust--including cameras, film, and projectors--long and expensive litigation was simply directed toward producers outside the Trust's reach, commonly foreign producers and imported film (Puttnam, 1997). By 1918 the U.S. government accepted the MPPC for what it was and ended its reign by breaking up the trust with a successful antitrust suit. With horizontal monopolization no longer legally viable, producers turned to control vertical distribution and exhibition to limit would-be competitors.

The Studios that filled the void were those who fled Edison's New York dominance to the other side of the country in Hollywood. This led to what was known as the Studio era (1915-1948), which was dominated by many of the same Major Studios we know today. This was when the trade association MPAA was created in $1922 .^{2}$ While the horizontal monopolization was ended for these new Major Studios, the vertical monopolization was still ripe for abuse. As exhibiting theaters tended to be more independent and smaller than the larger production/distribution companies, the latter had an advantage. If the exhibitors wished to purchase the more popular films from the large studios they were given conditions attached known as blind and block booking. To purchase the desired film for exhibition, theaters had to purchase a "block" of less desirable films from the producer, commonly unaware of what the block of films were even made up of (Seabury, 1926; Bakker, 2003). While this was surely a method to squeeze more revenue from exhibitors it was also designed to limit competition among producers/distributors. With a block of films purchased for exhibition, screen time for

\footnotetext{
${ }^{2}$ Paramount, Fox, Universal, Warner Bros. and Columbia were founding members. Disney joined later, and MGM, UA, and RKO were founders who eventually were purchased or went bankrupt. More recently Fox was also purchased by Disney, but played a much larger role in all eras of the MPAA and Major Studio dominance.
} 
films by other producers became scarcer. This placed small, independent studios in a secondary tier, used to fill gaps in block booking.

While exhibitors had little recourse during the MPPC's reign, after the breakup exhibitors began fighting back against the relatively larger producers by forming "theater circuits." These were collectives of theater owners that banded together for more power during negotiation and film purchases. This was an attempt to limit unfair practices, such as blind and block booking, but was fairly unsuccessful (Seabury, 1926; Balio, 1995). Some distributors responded with their own form of horizontal consolidation with so called "film clubs," which, just as theater circuits, was used to increase negotiation power. More importantly, however, was that larger distributors found they could simply purchase theaters until they had a controlling share of the circuit. While falling short of the horizontal monopoly practices of the MPPC and therefore deflecting attention from antitrust regulators, this vertical consolidation nonetheless unified the "functions of production, distribution and exhibition to the inevitable injury of every other producer, distributor and exhibitor" (Seabury, 1926 p. 65).

These practices continued in the following decades until all three sectors of production, distribution, and exhibition were united, resulting in a surprisingly "Fordist" method of film production. Movies were churned out with an assembly line of sets, writers, and directors. This was possible thanks to the assured profits from control of theaters. Even stars were contractually tied to particular studios. However, this came to an end as the regulatory environment of the New Deal finally caught up to the film industry after WWII. ${ }^{3}$ In 1948, the exhibiting portion of the industry was delinked from

\footnotetext{
${ }^{3}$ It is important to emphasize that the Decree came about after WWII, unlike other industries that faced stronger antitrust prior. Film and media have long had a strong relationship to Washington and even the military as a means for ideological influence. As will be discussed in later chapters, this relationship is even stronger today as the Major Studios are global and not just influencing American ideology.
} 
production and exhibition by the "Paramount Decree," forcing studios to divest their interest in theaters. The spirit of this vertical separation was continued in 1970 with Financial Interest and Syndication Rules (Fin-Syn), which stopped broadcast television and content producers from overlapping in ownership. As the major Studios declined in size and profit due to this stronger antitrust legislation, independent producers were able to fill in the gap and achieve better deals with the Majors. While the enforcement of both regulations would end in the 1980s, this interim period saw a rise of artistic and directordriven films as opposed to financially driven production.

Kirshner ${ }^{4}$ considers this time the "second Golden Age," following the first golden age of the Studio Era. Biskind (1999) has termed this "New Hollywood" as the industry became less hierarchical, not only around board meetings and producers, but also within the production as all crew members were afforded more creative freedom on set. This allowed for novel and boundary-pushing films like 2001: A Space Odyssey and The Exorcist to dominate the box office. However, Easy Rider (1969) is most commonly used to epitomize the era. With drug use, sex, and counterculture in the foreground, the small budget film was distributed by Columbia, grossing over 100 times its cost. The success of Easy Rider helped open other indie and micro-budget films to better distribution deals as the Major Studios looked for high-profit ratio films that would spark a cultural interest in society. ${ }^{5}$ Easy Rider was especially notable for its social commentary and idiosyncratic relation to American culture following the 1960s youth movement. While

\footnotetext{
${ }^{4}$ Kirshner puts a strong emphasis on the decline of censorship for contributing to the artistic surge. It is interesting to note that the MPAA was supportive of loosening censorship rules at the time. In more recent years as the oligopoly has strengthened, the MPAA has returned to a conservative interpretation of ratings and censorship, though not as harsh as the Hays Code and focused on self-censorship.

${ }^{5}$ This is in contrast to today. While there are more indie productions today than ever before in history, Major Studios are not dependent on these indie releases, and are usually to supplement Blockbuster revenue (Epstein, 2006).
} 
subsequent successes into the 1970s-- The Godfather, The Sting, Rocky--continued the director-driven nature of film, both the experimental and idiosyncratic nature were giving way to the blockbuster style (Jaws 1975 and Star Wars 1977), which helped restore Major Studio dominance just in time for sweeping changes under Ronald Reagan and Neoliberalism.

\section{Neoliberalism}

This transition toward deregulation and the return of oligopoly power under the Reagan administration were part of a broader shift toward neoliberalism. While this has a variety of definitions related to diverse aspects such as ideology and globalization, in relation to the power consolidation among the Major Studios of the MPAA, three defining concepts of neoliberalism are paramount: 1) A return of capitalist class hegemony in the social order, which in the film sector takes shape in the formation of large-scale media oligopolies that exercise power through financial ownership of high-value added activities within the industry (Duménil and Levy, 2013). While Duménil and Levy emphasize a class-based analysis, the return of such power configurations is heavily done through, and dependent on, the centrality of corporate oligopolies, such as media conglomerates. 2) As opposed to direct monopolization, control under neoliberalism is done in a diffuse manner around flexible specialization (Christopherson and Stroper, 1986), which allows leading corporations to bottleneck key sectors of an industry, such as finance and distribution for film, while other sectors are disintegrated and open to competition. In this system, smaller production studios exist in a competitive environment, where they remain dependent on leading corporations for financing, marketing, and distribution to market their products to wider audiences. 3) Finally, the neoliberal era is defined by the transition into financialization (Foster, 2006). This is 
manifested through ownership of Intellectual Property Rights, which is then leveraged as a financial asset by dominant media conglomerates. ${ }^{6}$

By comparing the distinct historical eras of film oligopoly, we can see as many structural consistencies of control, as well as the uniqueness of the neoliberal form outlined above. The early film industry's aggressive business tactics reveal key aspects of neoliberalism and the film industry during modern and early periods with little regulation. These include market control and consolidation, utilizing cartels to limit competition, and aggressive use of copyright to maintain market reach. The consolidation mentioned above reflects both horizontal and vertical monopolization of the product. As the chart below shows, even for an industry with a lot of natural propensity for concentration, corporations that own high-value activities under neoliberalism (ownership of intellectual property rights over film production and distribution, for example) have been able to broaden the power of their oligopoly. Corporate power under neoliberalism has been used to reduce regulatory oversight and to allow for a greater concentration of ownership of high-value activities within the film industry both nationally and globally.

\section{Aspects of Motion Picture Eras}

\begin{tabular}{|c|c|c|c|c|}
\hline & Early Film Industry & $\begin{array}{c}\text { Studio } \\
(\mathbf{1 9 1 5 - 1 9 4 8 )}\end{array}$ & $\begin{array}{c}\text { Decree } \\
(\mathbf{1 9 4 8 - 1 9 8 0 s )}\end{array}$ & $\underline{\underline{\text { Neoliberalism }}}$ \\
\cline { 2 - 5 } & Horizontal & Vertical & Horizontal \\
\hline Sector Focus & Panner of Control & Cohesion & Vertical \\
& & Theater Ownership & Production & Distribution Stream \\
& & & & Control \\
\hline
\end{tabular}

${ }^{6}$ See Zeller (2008) for the relation between finance and Intellectual Property. 


\begin{tabular}{|c|c|c|c|c|}
\hline Manner of & Studio Fordism & Studio Fordism & Smaller Studio & Finance \\
Production & & & Partnerships & $\begin{array}{c}\text { Management/ } \\
\text { Blockbusters }\end{array}$ \\
\hline Major Association & Edison Trust & MPAA & MPAA & MPAA \\
\hline Industry & No & Few Major & Greater Indie & Few Major \\
\hline Relation to & Foreign Film & Competition & Competition & Competitors \\
Foreign & Protectionism & Foreign Threat/ & Access & Market Access \\
\hline Legal Focus & Patent & Blind and Block & Fopyright Extension & Copyright Control \\
& Control/Litigation & Booking & & \\
\hline
\end{tabular}

The largest changes within the industry's hierarchy have been tactical, rather than strategic. These major tactical changes are represented by the first three rows in the chart. Manner of Control is how the oligopoly is delineating itself through barriers of sector ownership. This is directly related to antitrust enforcement, with no regulation leading to full monopolization and weak enforcement resulting in vertical monopolization, which defines both Neoliberalism and the Studio era. Only post-Decree did the Major Studios have trouble with cohesion of the oligopoly due to lack of sector ownership. The sector focus itself has probably seen the greatest variance, as this is more related to distribution and exhibition technology, rather than solely on politics and law. With so many distribution platforms these days, ${ }^{7}$ rather than only theaters and television, the Major Studios and their parent companies need to be very dispersed with their Vertical

\footnotetext{
${ }^{7}$ While the largest and best known are Netflix, Hulu, and Amazon Videos, individual studios have increasingly focused on developing their own platform for exclusive content, such a Disney+ and HBO Go.
} 
Monopolization. To limit costs associated with these multiple distribution platforms, the Major Studios focus on controlling and expanding Intellectual Property Rights, which are financialized within neoliberalism. This allows for specialization in "must-see" blockbuster franchises released around the world, which have a relatively assured market that can be released through multiple streams. This also keeps the most profitable films out of reach of indie studios due to costly productions, unsecured distribution, prohibitively expensive acquisition of franchise intellectual property or development through costly advertisement campaigns.

In turn, the largest consistencies of the industry revolve around the number of major competitors and the degree of association of those members. Once again, only during the Decree period under strong antitrust enforcement did the industry see a decline in oligopoly. This was the largest decline of market share for the Majors until its culmination, which saw the largest change within the MPAA organization (covered in chapter 2). The associations themselves are the most consistent element of the oligopoly. Edison's MPPC trust had no major competitors, but itself was formed out of the major studios of the time--largely Edison Studios and Biograph. The demise of the MPPC was immediately replaced with the MPAA. Though the Paramount Decree weakened the oligopoly, it did nothing to the trade association, which allowed the organization to recoup its political influence and help usher in neoliberalism and deregulation. As the Major Studios grew, they increasingly looked to foreign markets to reinforce influence and offset production costs, and subsequently copyright extensions needed to be expanded globally.

As a result of deregulation, corporate concentration, and new media technologies, the studios became firmly incorporated in Mass Media Conglomerates (MMC) that control major film production, distribution, exhibition in theaters, television, 
cable, pay on demand, and other media forms such as newspapers, magazines, book publishing, and even toys and theme parks. This control limits independent studios in distribution terms, as they now need to distribute through a Media Conglomerate stream. Like the previous eras, any room for independent films will be limited and help feed the profits of the Major competitors. The result is a secure position for the Majors as any lower competition will likely feed into their distribution. This additionally makes it extremely unlikely for changes in the hierarchy of the film industry. Any large independent studios, or "mini-majors," that begin to compete with the majors are purchased and incorporated into a Mass Media Conglomerate. This lack of competition allows assurances of profit for the Majors, which in turn allows further hierarchization through blockbuster finance, foreign markets, and copyright control.

As the Mass Media Conglomerates have concentrated and dominated the domestic market, they have also expanded their international reach, with over 50 percent of revenue coming from overseas. The distribution size and control, financial security, and political backing allow the Mass Media Conglomerates to expand their market power well beyond the capacity of smaller studios. Thus, international copyright rules, such as incorporated in the World Trade Organization and other regional and bilateral trade agreements, and the support from Washington are essential to the global success of the Majors. This domination of foreign markets, in turn, allows for larger conglomerates in the home market, again crowding out smaller competition. What we are left with is the perpetual domination of the industry by the Major Studios and their parent Mass Media Conglomerates, with little hope of growing competition at any point of the distribution stream.

Central to this internationalization and monopolization is the change in production and film style. As the Fordist production of films limited smaller studios without the funds 
to replicate the process, "Blockbuster" profits exclude all independent studios unable to raise the massive funds required. As the restructuring of the film industry during the ' 80 s was financed by Wall Street, the end products of Mass Media Conglomerates were required to have a secure profit to ensure repayment on the investment. This assured profit comes from both the distribution and the size of the conglomerate, which allows access to finance in the hundreds of millions of dollars to produce a film. With the necessity of high advertising expenditures, the extensive deployment of financial capital is required to turn a film into a Blockbuster. With independents unable to compete at such a high level, Blockbuster films from the Majors dominate their own distribution steams, crowding out lesser known intellectual properties. This assures a home market and revenue stream for the Majors, from which they extend to foreign markets, which are again out of reach for most independents.

Vertical integration has created a synergy between the products, distribution, and exhibition. As Prince has argued, the new Media Conglomerates making up the major film studios no longer made films, but "filmed entertainment" (2000, pg. xi) which would be repurposed into the old and new distribution mediums, but also into new ancillary markets such as toys, print media, and even theme parks. Thus, film was no longer a product of its own, but just one iteration of an intellectual property chain. Films themselves could be shown in theater, cable, pay-per view, and television, while the characters and story could be refashioned into television shows, books, comics, and toys. It was argued that these various means of distribution needed to be combined to gain the synergy and efficiency necessary to market Intellectual Property Rights. Added to this were the complications of having multiple means of distribution beyond only film and television. Washington no longer saw it necessary to regulate such a diverse industry. If one means of distribution is not perfect for the consumer there are many 
others. With these arguments in hand, industry lobbyists were able to successfully remove anti-trust regulation from the industry.

\section{The Evolution of the Neoliberal Era: Contemporary Scholarship}

The scholarly literature explains the trends associated with the neoliberal era in film from a variety of angles. For example, Wasko (1994) takes up the importance of technological innovation to explain the consolidation in media and film. The new mediums of cable and home video extended the market of filmed entertainment, but were also used as a reason to liberalize the market. With so many growing distribution streams for film and television there was no reason to bar producers from theater ownership (Paramount Decree) or broadcast (Fin-Syn). However, the end result was that the majors would enter and largely dominate all these distribution streams simultaneously. Rather than grow competition, this allowed for a growth in the size of the majors and their economies of scale to produce expensive blockbusters. The varied distribution and expensive production thus support one another, and also limit the distribution option of indie producers. Films from the Majors fill the majority of their distribution, but independents are also heavily reliant on their distribution system, making competition outside of the Major's supply chain quite small.

Wasko also argues that the move into various distribution sectors is directly tied to the development of Mass Media Conglomerates and the focus on vertical monopolization. While this provides a very strong examination as well as foundation to future strategies within the Majors, such as moving into digital distribution, it places too much emphasis on technology as the reason for monopolization, resulting in a deterministic conclusion. As a result, it diminishes other factors in politics, the economy, as well as within the industry and corporations, and largely considers monopolization as 
an inevitable consequence of technological advancement. New distribution sectors and a larger industry were undoubtedly used to push liberalization, but it is also likely that the Majors would have reconsolidated their position regardless of that development.

Holt (2011) has a better account for this problem by accepting the change in technology as a variable, but also including neoliberal ideology as another independent variable. In this way, Holt argues that the introduction of new means of distribution in the 1980s reduced the need for regulation against vertical integration. Horizontal monopolization would continue to be forbidden, but now distribution streams could be synergized. Efficiency would be increased as the Mass Media Conglomerates came into existence, uniting production, distribution, exhibition and, increasingly, Wall Street. However, Holt argues that this deregulatory environment would have never come about if neoliberal principles did not contribute to its legitimacy. She especially emphasizes the inauguration of Ronald Reagan and his placement of William Baxter as assistant attorney general in charge of antitrust, and Mark Fowler as chairman of the FCC. Armed with an ideological goal of deregulation and legitimation for their decisions by technological change, these individuals drastically changed the corporate landscape of the economy.

By focusing on the ideology of leading individuals, Holt provides much needed political and human agency elements to the literature. Even without new distribution technology, the monopolization can be explained by neoliberal ideology endorsed and advanced by the President and the executive branch. Unlike the reliance on the technology variable, which can only explain monopolization in industries that likewise had transformative innovations, the ideology variable can be used for all industry transitions. As a result, the technology variable is more descriptive specifically to the motion picture industry, while ideology has more general explanatory power. Where Holt 
has trouble in her analysis is in explaining how and why the ideology shift took place. Rather than focusing on literature critiquing neoliberalism as an ideology, Holt turns to an individual analysis. Thus, it is in Reagan's presidency that neoliberalism as a variable is found. More specifically this is done in the embodiment of Reagan, Fowler and Baxter. This method is flawed in individualizing the variable well past its utility. If Baxter, and especially Reagan, were not in power, would neoliberalism have spread? This variable would be unable to answer this question as it is too devoid of structural and systemic considerations.

Miller et al. (2005) are able to avoid limiting themselves to overly specific explanatory variables by mixing critiques from political economy and cultural studies. The authors argue that "Hollywood" no longer exists. Rather, "Hollywood" in reference to the film industry explains both the internationalized production of film as well as the global distribution, none of which are limited to Hollywood or even the US. As such, the film industry is also part of the global production chain, which seeks out the cheapest production, pits workers' interests against each other, and distributes in a different location from production. In this way, the scholars are able to offer rich detail on the Motion Picture industry, with a theoretical framework applicable to other industries. On the political economy side, Miller et al. agree substantially with Wasko's argument that the economic power of the major studios lies heavily with distribution, especially in the global market. However, Miller et al. also incorporates production, showing how film conforms to the general trend of internationalized production. This is done by showing how the term "Hollywood" no longer applies to the industry, with filming, special effects, and other components done around the world where the cheapest labor can be found.

On the sociological side Miller et al. take methods such as "domestic effects model" (DEM), which assumes a psychological effect of film on the viewer, and the 
"Global Effects Model" (GEM), which focuses on the national, patriotic, and cultural reaction to foreign films. By combining these methods the authors are able to show how large flows of American films have a "cultural imperialism" effect, which in turns creates more demand for American film and thus greater market share. This focus leads to an approach that is heavily reflexivist and normative in scope. While initially providing much detail to the material power of the Major Studios, the initial concern of the authors is "...Yanqi [Yankee] domination and wholesale commodification at the expense of the marginal and the oppressed." (Miller et al., 2005, pg 48). As a result, the level of analysis here tends to move back and forth. The focus is both on individuals, in the form of foreign viewership, and cultural imperialism, which can take the form of corporations or America as a whole. Where the analysis is weak is in explaining why foreign states will accept this cultural imperialism, and the political power of the corporations themselves, especially in relation to the domestic population.

Epstein (2006), like Miller et al., provides a heavy use of statistics and details about the economics of the motion picture industry. Like Prince, he focuses on how film has transformed into intellectual property, and thus has multiple means of distribution in different forms of media. Epstein, however, takes this one step further with greater acknowledgment of the power of the Mass Media Conglomerates, which the major studios exist within. As a result, he is able to reveal the amount of collusion that takes place among these media conglomerates, both among the six majors and studios outside and all to the disadvantage of competitors. While Epstein provides a strong foundation to understand the operations of the Majors and collusion within the MPAA, his journalistic focus on details lacks a systemic understanding of oligopolies and associations that can easily be applied to other industries with similar structures. 
Steinbock (1995), likewise, takes a historical and detail-oriented approach in his examination of the general media and entertainment industries. In this way he also provides rich data, details, and statistics, but also lacks theoretical explanations. As his goal is to provide students within a multitude of fields with historical information about the patterns of consolidation, his approach is understandable. However, unlike Epstein, Steinbock largely ignores the political and cartel-like actions of the Majors. In this way Steinbock makes little effort to explain any elements contributing to corporate power in the broader economy, much less the spread of neoliberalism.

Puttnam (1997) also examines the early history of the industry, starting even before the 1900's. What he is able to reveal is that, from the very birth of film technology, economic, political, and international conflict has existed in the industry. Offensive use of costly litigation has been a hallmark of combating competitors, which fostered a great need for political associations by studios. Political connections were especially necessary when creating Edison's Trust, the Motion Picture Patent Company, which monopolized the industry through protective patents on film technology. Especially important in defense of this monopoly was the need to keep out foreign imports. Within the Trust, two French film companies joined a majority American coalition, which combated domestic competition and offered no room for other imports.

However, Puttnam is following a much more politically neutral, historical analysis. As a result, his strong example of the Motion Picture Patent Company's political, legal, and economic power is largely left as a result of Thomas Edison's personal style of business. As such, if it was not for Edison the collusion, monopolization, political affiliation, and foreign aggression would not have occurred. This reliance on the individual limits Puttman's analysis to a historical particularity. As a result, there is little possibility of generalization or explanation of how these same trends continue on, except 
in the nature of other leading individuals. While later leaders, such as Jack Valenti, head of the MPAA (1966-2004,) were undoubtedly important in shaping the industry, this analysis misses not only structural and systemic conditions, but also the nature of class and corporate interests.

\section{Internationalization, Intellectual Property, and Corporate Power}

To examine the causes of the 1980 s shift to neoliberal policy it is important to develop a strong understanding of neoliberalism. As it is a very broad term, neoliberalism can relate to many topics, such as a policy orientation. At the same time neoliberalism can mean the laissez-faire ideology that it purports itself to be, but also particular contradictions of capitalism, such as monopolization, that directly contradict the laissez-faire assumptions. Harvey (2005) is able to bridge this gap by focusing on neoliberalism as an ideology. By utilizing multiple levels of analysis, rather than focusing on individuals as done in previously mentioned work, Harvey shows how such a large economy-wide shift in policy could occur in a relatively brief period of time. In this way, the monopolization of the film industry was not simply the result of dictates by regulators, such as William Baxter or Mark Fowler, but the result of a broad shift of political consensus, not only by the elites but also the general population. Harvey reveals the gradual indoctrination of universities, corporations, and even local politics to neoliberal policies that benefit the elite. This is a cultural and political shift that the media industry has a particular stake and influence in.

In lobbying and association terms, the film industry was not an isolated industry, but part of a much broader movement to affect this change. Within this, the utilization of the technology argument for deregulation, or the need to gain new synergy between multiple intellectual property products, provides assistance to other industries and 
corporations that are fighting for similar deregulation. As such, one industry would not have been able to alter regulation on its own. Each industry or corporation operated tacitly toward a general beneficial goal. For the film industry, this required deregulation in all copyright industries that became part of the new Mass Media Conglomerates, but also, more generally, with other intellectual property industries such as pharmaceutical or technology corporations.

As mentioned, the nature of the major's political influence, monopolization, and market control relate heavily to its use of intellectual property law, and especially the internationalization of these laws. Starting from the use of patent protection to intimidate or financially ruin competition, under neoliberalism copyright has become an important tool for both opening foreign markets and maintaining intellectual property control. In opening up foreign markets the WTO's Trade-Related Aspects of Intellectual Property Rights (TRIPS) and U.S. support in Section 301 of U.S. Trade Law has been essential. The extension of length, scope, and geography of copyright and intellectual property has likewise been essential for maintaining profit of intellectual property from film into other arenas such as television, books, music, and toys.

Boldrin and Levine (2008) attack the concept of intellectual property directly by analyzing the intended purpose of the laws. The notion that intellectual property is required for growth and technical innovation is repudiated with an historical analysis of what came first, as well as under what legal regime innovation heavily occurs. This is done by showing that IP rights, or monopolies as the authors describe them, are increased only after the majority of the innovation had already occurred. In this manner, IP rights either follow bursts of technological innovation after they occur and slow on their own, or they actually slow down the innovation themselves. The ownership of patents works to stifle competition and slow the spread of knowledge and technology. As 
a result, the authors argue the burst of innovation is stopped by IP laws rather than protected and encouraged by them.

While this nature of IP may be most obvious during the aggressive patent protection of Edison's time, today's use of IP by Mass Media Conglomerates shares many similarities. As mentioned, film has shifted from an isolated medium to one of intellectual property designed to exist in a multi-media format. Boldrin and Levine argue that this expansion of IP ownership eliminates public and creative control of popular icons and assets, reduces culture, and thus consumption, to the Mass Media Corporations that control the IP. This also reinforces the monopoly on distribution, as the Majors control the leading streams and revenue. For IP outside of the Majors, this means relatively limited profit on IP as well as weak negotiating power over the term of distribution. Finally, the multiple streams of revenue reserved for the Mass Media Conglomerates allows the possibility to fund the outrageously expensive Blockbusters that allow the multiple streams of distribution. Without this financial revenue independent studios have little hope to compete on the screen, which cyclically limits other revenue streams (books, TV, toys), again limiting film budgets.

Sell (2003), however, properly accounts for the influence of actions of corporations and individual CEOs in the creation of TRIPS. In this way she is able to escape the structural determination that emphasized TRIPS as an agreement for the benefit of developed states, conceptualized as a unitary actor. Instead Sell shows how the interest of the state was instrumentalized to push forward the interest of IP corporations into international law. By this level of analysis, Sell can more clearly define whose interests are promoted and why, rather than generalizing entire states and structures. 
Sell does this by showing the effect that lobbying and trade associations had on US policy positions in the Uruguay round of GATT and how it changed the system of international Intellectual Property Rights (IPR). Initially international IPR relied on the World Intellectual Property Organization. However, an institutional change occurred with the creation of TRIPS within the WTO. This shift was brought about by the creation of the Intellectual Property Committee, composed of 13 CEOs from IP related corporations, and its efforts to direct US policy goals in the WTO negotiations to reflect maximalist IP laws. Perhaps most important to Sell's argument is her counterfactual for alternative IPR measures, such as maintaining the importance of the WIPO. As such, she argues there was no structural necessity for the outcome. This is in contention with arguments that developed states will inevitably push for rules to maintain their relative position. Instead, the creation of TRIPS was a direct result of specific actors, corporate power, and lobbying influence by the elite.

Although Sell focuses on the actions of the IPC, PhRMA, and other IP related trade associations, this analysis of corporate power can easily be generalized to the larger economy as is done by Cox (2012). Similar to Sell, this is done to show the process of neoliberalism and internationalization of production is not an inevitable position of developed states. Indeed, many of the neoliberal policies are quite harmful as they lead to decreased productivity, over-consumption, and financial crises. As such, the level of analysis must be directed at corporate power, elites, and powerful individuals. Ultimately, the international agreements and policies pursued are not simply due to the national interests of a state, but a general class and oligopolized corporate interest. Just as production has been internationalized under neoliberalism, the lobbying power and corporate associations become transnational in their reach. Much as both PhRMA and Media Conglomerates lobby the government on complementary topics, the general 
corporate push for neoliberalism appropriates state power across borders. The success of such policies depends on the effectiveness of transnational corporate collusion, while failures are commonly the result of divided corporate interests.

This conceptualization and method is complemented by McChesney (2001), who views the spread of neoliberalism merely as the most recent iteration of class struggle within capitalism. As such, neoliberalism conflicts with the notion of small government and deregulation. Instead what is pushed is "re-regulation and larger government to assist corporations and minimize "any activities that might undermine the rule of business and the wealthy" (McChesney, 2001, pg 2). Under this conception, the power of the corporate cartels has a strong structural element. The structure of capitalism will naturally lead to monopolization of industries, which in turn will lead to appropriation of government to develop political support. This view tends to discredit the possibility of alternative counterfactuals as well as the uniqueness of this particular iteration of class struggle. Although McChesney argues that neoliberalism reduces democratic influence, and thus implicitly accepts the possibility of democratic control, by focusing on economic monopolization prior to political influence McChesney lacks the proper emphasis of how specific details of neoliberal policies affect and interact with the monopolized market, society, and international relations.

May (2000) also focuses on the conception of neoliberalism in his analysis of the spread of IP regime. Unlike McChesney, who focuses on economic power, May is almost entirely concerned with neoliberalism and IP rights as an ideology. May does argue for a "dual-dialectic approach," in which one analyzes the structure in relation to people and ideas. However, he almost entirely focuses on ideas in what he calls the knowledge structure. In this he does very well in showing that IPR is not a natural phenomenon, but crafted over time. May agrees with Boldrin and Levine that IP was 
created by corporations and individuals who will benefit from it, at the cost of others. May is able to take this understanding and show how IP itself is a core and essential aspect of the neoliberal ideology in a similar form to McChesney's understanding: government support of corporate interests. However, May lacks an explanation of how this change in IP came about. He simply claims that corporations spread this ideology, but does not explain how or why their corporate power is so immense.

This understanding of a global economy and changing interests of class and state is immensely important to delineate the shift to neoliberal policies as well as discovering the role of the film industry within the neoliberal period. As foreign markets became increasingly essential for the Hollywood Majors for both sales and production, Washington has acted as a transnationally powerful state to defend these interests. By leading trade negotiations, free trade agreements, and defining and enforcing international Intellectual Property Rights, the U.S. has adopted corporate interests as its own. By allowing monopolization, market control, and political support the U.S. has assured success in the global film industry. However, this need for support is a result of the globalized economy, which was heavily shaped by the U.S. and allies at the behest of corporate interests. This ostensibly ties corporate and government interests together for the success of the domestic market, but reduces labor benefits, increases government cost, and increases corporate profit and power. This analysis thus requires a theoretical conception that will emphasize how both state and industry collude together, as well as how industry colluded itself to recreate cartel structures.

\section{Associationalism}

For neoliberalism and the film Industry in particular, trade associations have been used to promote cartel structures. In this section, I will develop an expanded 
understanding of trade associations, before examining the mechanism through which they expand their influence into other actors and systems. Historically, trade associations were more interconnected to promoting the interests of competitive businesses in free market capitalism, especially during the period of early industrialization (Galabos, 1966). Today much of the academic focus on trade associations revolves around their role in lobbying and member representation. Scholarship often fails to analyze the way that trade associations have promoted a concentration of corporate power within neoliberal capitalism. Especially for oligopolies, trade associations tend to look and act more like cartels. As such, the roles of trade associations in facilitating neoliberal policies and monopolization extends much farther than is commonly understood, including the following areas of influence:

- Price controls

- Relations to labor

- Governmental reach/regulation

- Distribution control, including networks and platforms

- Opening foreign markets/developing export markets

- Competing against foreign competitors

- Protectionism

- Developing and enforcing laws

- Lobbying and other governmental influences

- Public relations

- $\quad$ Agenda setting ${ }^{8}$

- Statistics and research

${ }^{8}$ See Fuchs (2007) for more. 
- Shared facilities

- Standardization/compatibility

- Patent pooling

- Joint ventures

- Delineate territory

- Subsumed smaller business/potential competitors

- Self-governance

- Influence laws and set legal precedents

- Influence norms, international and domestic

I use the term "associationalism" to describe the ways in which trade associations provide a vehicle for promoting the political and economic interests of their members through cartel-like functions. This means that trade associations have increasingly been used by corporate oligopolies to promote political and economic cooperation within the market and the political arena. In the area of media consolidation, the MPAA has emerged as a vital link between a range of corporate actors that seek to acquire more control over the highest value-added activities in corporate ownership and production. As will be explained in detail below, corporate trade associations do not just promote the interests of their corporate members, but their activities are closely bundled with powerful corporate actors in related sectors to produce a mutually reinforcing corporate power network. In order to fully appreciate the way that modern-day associationalism operates, I borrow from the work of Robert Brady, who articulated the concept of Control Pyramids to illustrate the overlapping corporate power relationships that are embedded within associational structures. 
Robert Brady used the term Control Pyramids (1943) to explain a particular manner of associationism ${ }^{9}$ generated by corporate alliances. Brady was examining fascist economies and noted that the corporatist method was not so distinct from Western economies. The major difference was that the businesses structures in the West were more dispersed, less absolute, and not as directed by and for the state. Yet, what was similar was a clear hierarchy being directed by leading corporations. These corporations would work together to unite industry dependence--including smaller businesses, but especially labor--and then use this larger industry-wide leverage against the state, thus forming a hierarchical pyramid structure. These dispersed relationships can be benign, especially in comparison with fascism, but constituted what one might consider "corporatism-light." ${ }^{\text {"10 }}$ With fewer firms making partnership and collusion easier, power dynamics can be shaped into disproportionately powerful coalitions. With clear industry leaders and megacorporations, the "controller" of such Control Pyramids is clear.

Illustrative of such Control Pyramids is the graphic below, revealing a central point for an institution such as the MPAA. The actor that can best direct one pyramid will have bounding power and influence to direct broader ones in a particular way, resulting

\footnotetext{
${ }^{9}$ The idea of associationalism itself came about around when Trade Associations and trusts were being institutionalized in the 19th century. The idea was that industry and businesses needed to work together to limit any negatives of competition, such as depressed wages or volatile prices. While Keynesianism, with a more socially oriented macroeconomic management, diminished associationalism as a theory, the practice of industry partnerships continued.

${ }^{10}$ It is important to differentiate a concept like corporatism-light with the "Neo-corporatism" which is still in use in many Germanic economies (See Schmitter and Grote, 1997). Corporatism as conceptualized by Mussolini was a social structure whereby individuals were to have no say outside of their economic sector, which was represented by industry leaders (going so far as to replace parliament with the "Chamber of Fasci and Corporations"). While this was done top-down and directly by the state, corporatism-light can be seen as such influence generated outwards by the leading corporations and tacitly accepted and then supported by the state. Neo-corporatism, by contrast, retained mild state management of corporations, but with the intention of focusing on labor interest, opposed to corporate interests.
} 
in a drastically hierarchical structure. The structures that result, both within film and nearly all other industries, are important improvements over traditional analysis of corporate power. The concept of Control Pyramids helps explain how agency shapes the system and structure through overlapping associations, interests, and partnerships. This reveals a structure that allows members, even those not especially powerful, to have a larger influence, making the sum of corporate power, at least those integrated into such a system, larger than its parts. This also allows for the inclusion of more actors than simply the direct relationship between corporations, governments, or politicians.

\section{Control Pyramid Graphic}

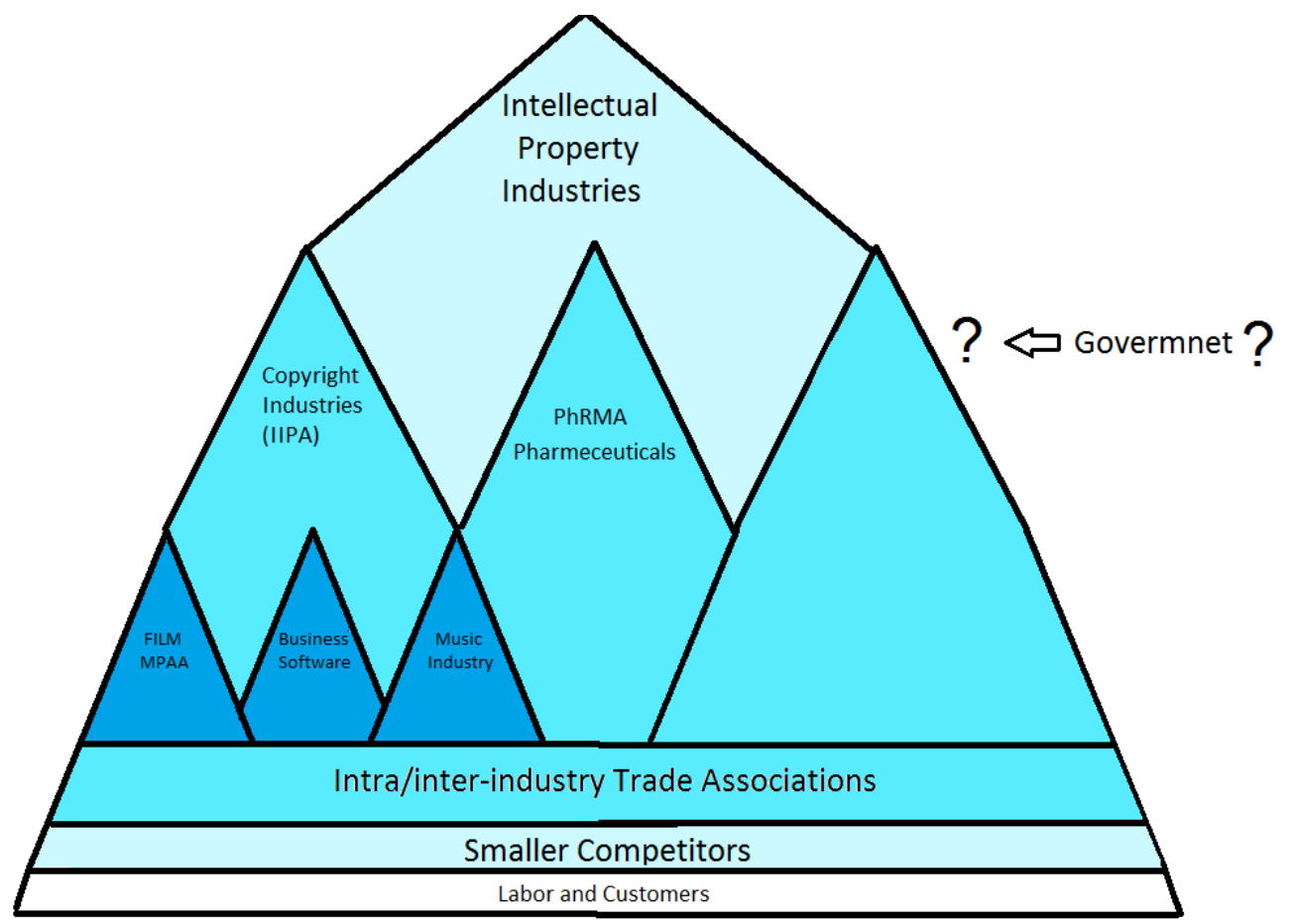

MPAA and Associationalism: The graphic above is a conceptualization of the bounding power of corporate associations and coalitions. As leading corporations develop their own industry hierarchies, they can then participate in generating broader 
means of control, usually in related industries. As the MPAA nominally represents the film oligopoly, its most immediate natural partners are other copyright industries. However, as the major studios are already part of Mass Media Conglomerates, many of these are already inherently represented by the MPAA or one of the sister organizations, such as the Recording Industry Association of America. ${ }^{11}$ With this the Mass Media Conglomerates will have strong leverage in directing the influence of the broader copyright industry. One such organization is the International Intellectual Property Alliance (IIPA), which is, in effect, a trade association of trade associations. The IIPA works to extend copyright internationally, with a focus on bilateral and FTA treaties. This greatly expands leverage as several industries use one voice, however with the MPAA (and its members) as a member and an independent partner in such activities.

As each pyramid is bounded into a larger structure overlapping coalitions are formed upward. Unlike traditional corporatism, this upward association tends to be more dispersed as actors become more numerous and diverse interests are more difficult to reconcile. However, while the peak association is less cohesive, the pyramid itself is larger, as is its base. Also, as the larger pyramids are less organized, this allows more room for the most active and consolidated association to have a larger influence in directing and representing larger coalitions. The MPAA, being one of the more politically and publicly engaged, as well as most cohesive, is one such organization. As such, as will be seen in later chapters, media and the MPAA play an important role in shaping IP law and trade agreements. This is particularly true with the pharmaceutical oligopoly's association, PhRMA, which partners with the MPAA, both tacitly and directly, in shaping many aspects of intellectual property. While this explains the upward bounds of the

\footnotetext{
11 The RIAA also has Universal, Warner Bros, and Sony as members.
} 
control pyramids, important to their size and leverage is the foundation composed of actors dependent on the "controlling" corporations.

\section{Overlapping Trade Association example: FACT, IIPA, and DCA}

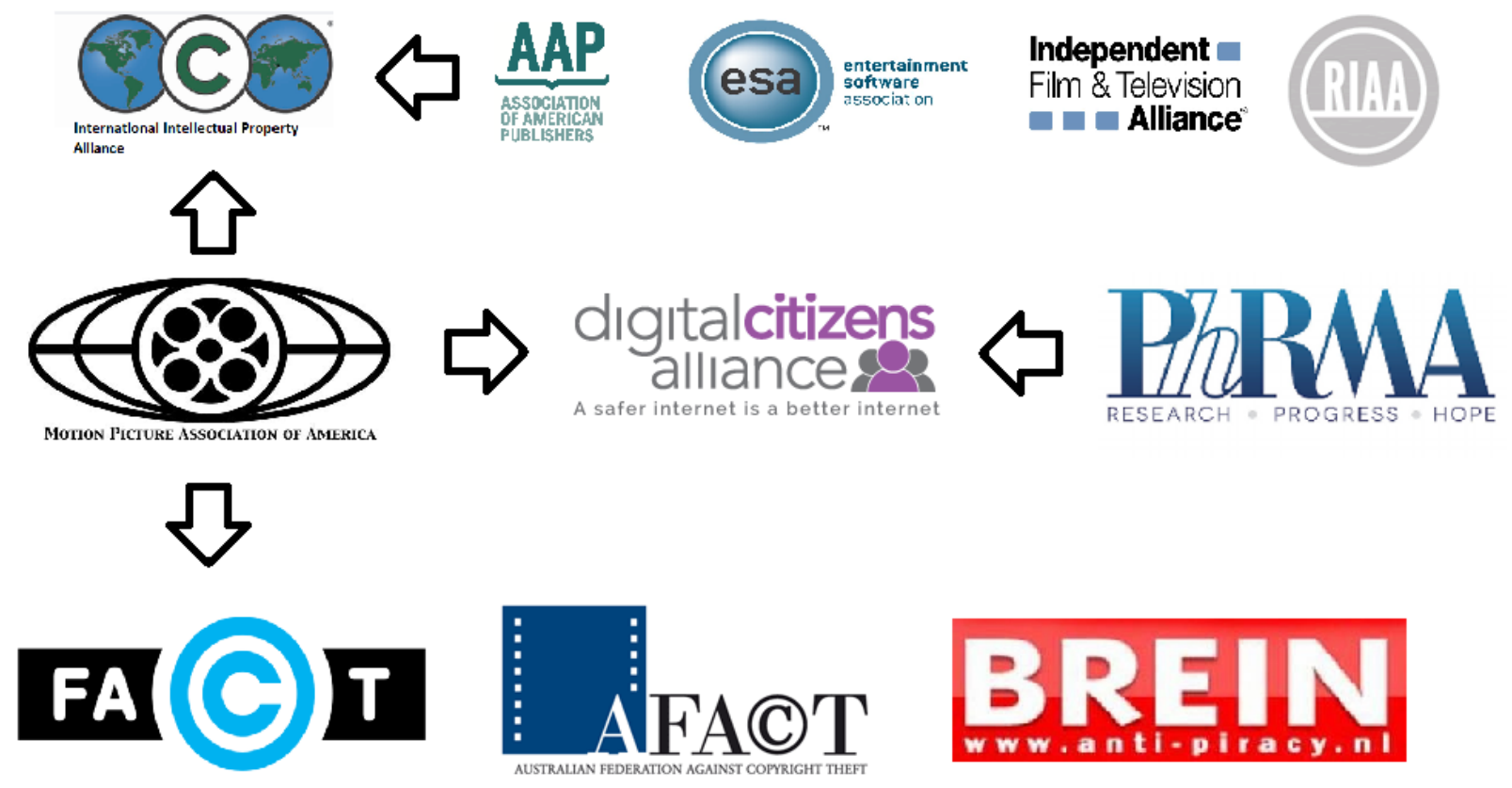

Labor For the leading corporations to leverage the entire industry (and appear as its representative) its primary foundational need is labor, which is also typically the most dependent. Typically, labor is either seen as victim to asymmetric corporate power, or, when properly organized, a leading balance against it. However, with union membership declining since the 1950s, a dependent, and thus supportive, relationship has developed. As labor became weaker, production became mobile, and jobs became more precarious, the rhetoric of structuring the economy around job production and market efficiency became the norm, opposed to higher wages and greater stability for workers. Around this, a dependent and vulnerable labor will be more likely to support corporate 
power and comparable state support. In film this can be seen as far back as the 1940s, but especially developed with the increased mobility and internationalization of film production (more in chapter 4). As opposed to negotiating for job quality, unions increasingly support corporate subsidies from states, and film friendly and supportive state policies. While places like the EU retain greater union membership, they too have been directed toward using their membership to support subsidization, corporate empowerment, and jobs and competitiveness, which has increasingly become a global trend.

Small businesses tied to major corporations have also seen a dependent relationship develop over time. Indie producers and studios operate on a fine line of being competitors to the major studios, but also viewing them as necessary partners to access much of the industry. Beyond distribution and access to exhibition sectors, this also includes working on co-productions with major studios for financing and larger budget productions. As a result, many of the mid-tier production companies around the world actively work with local governments in attracting blockbuster productions to bring in jobs and investment. Because indie films are unlikely to get broad releases, advertisement campaigns, or large funding, without partnership with a major studio, many of the leading indie studios are supportive of the two-tier studio system, opposed to a generally competitive environment. This also leads indie studios to partner with majors and unions in supporting and expanding local subsidies, not only to attract blockbuster production, but to also get a small piece of a larger subsidy pie.

The State With the inclusion of labor, consumers, and smaller competitors in the Control Pyramid structure, where and how the state fits in is especially important. This is because the state has a large hand in directing the system and the structure, and also is theoretically the central bridge between citizens (labor and consumers) and leading 
corporations. As seen in figure Control Pyramid Graphic, the state can ultimately have a varied position, depending on the goals and the relationship to the existing corporate structure. No doubt, as corporate power has grown over time and many states have adopted a role of facilitating corporate friendly markets, as well as direct corporate support, the state has generally moved down the pyramid, increasingly becoming a dependent of the system as opposed to an organizer or moderator thereof. This results in the rhetorical and ideological promotion of "competitiveness," of which market efficiency around oligopolies is only one part. The need for the state to actively and directly support corporations and defer to their interests has resulted in the quintessential uniqueness of neoliberalism--that peak corporations utilize neoliberalism, but do not conform to the free market ideology. Despite the neoliberal rhetoric of free market, free trade, and laissez-faire policies, we see today that state support, oligopolies, and corporate collusion are as strong as ever before.

As a result, states become captured by the structure and leading actors, rather than pursuing the more difficult goal of generating rules, laws, norms, and a system that balances the structures of market power. Under neoliberalism, leading corporations are supported by states in numerous ways. States liberalize antitrust laws to develop globally competitive multinational corporations or global oligopolies that become essential for jobs, investment, and trade. States also create institutions and international organizations that will normalize and entrench leading corporations. In addition, states liberalize and open foreign markets when domestic corporations are strong or otherwise protect or support corporations when they are weak. They directly or indirectly subsidize industries to improve competitiveness or to attract investments. They protect and expand international investment, property, and Intellectual Property Rights. Finally, they develop an environment where leading corporations have free range to develop international 
associations, pursue corporate diplomacy, or develop corporate-state coalitions to reshape the existing rules and norms.

The effect of the bounding power of control pyramids is that the tacit cartels, such as the MPAA, have much greater power and influence than they otherwise would have. Their power comes not only from monopolization and sector control within the industry, but with developing coalitions and associations with a variety of actors, either with similar interests or with a dependent relationship with the leading firms. This puts the MPAA at the center of not only film and media, but copyright, intellectual property, and other neoliberal policy issues. This is also essential to understanding how and why many states end up playing a supportive role for leading corporations, rather than labor or consumers. Due to the intersecting nature of this manner of analysis, it will be important to examine the qualitative methods that will play a part in my analytical framework.

\section{Methods}

This examination of monopolization and political power of the Motion Picture Industry will be analyzed as a case study, which will reveal broader implications of neoliberalization. I will do this with a combination of process tracing, utilizing theoretical framing, and substantiating my argument with statistics and economic data. By utilizing a detailed process tracing, this study will expand on the current scholarly literature, which heavily limits itself by focusing on variables outside of the industry. According to many scholarly accounts, both technology and ideology are imposed upon the film industry, excluding the agency of the corporations in their restructuring. Incorporating corporate power as a variable will reveal this role of corporate agency, as well as exposing corporate, class, and government relationships within neoliberalism. 
Much of the literature covering the neoliberal and monopolization process of the Motion Picture Industry tends to rely on fairly selective independent variables. Because much of the literature comes from Film Studies, Business, and Communication, it largely accepts the neoliberal narrative of natural progression to a global economy. This leads to a heavy emphasis on new technology in the 1980 s being the primary variable for the shift. This explanation brings the invention of new means of distribution and exhibition, such as VHS and cable, to explain the development of the Mass Media Conglomerates. This has been done by showing how the new technology increased the level of complexity, decreased the importance of older exhibition, and created the potential for new means of synergizing movies with other forms of media and intellectual property.

The problem with this emphasis on technology is the lack of analysis of human agency. This scholarly emphasis on the impact of technology reinforces the assertions by neoliberal proponents about what led to the 1980s transition. This technology narrative views the monopolization that occurred in the motion picture industry, and most industries in general, as natural and inevitable. The lack of human agency in the analysis leaves, at best, a historical narrative that describes some of the events that took place, but is poor in explaining why it occurred and in analyzing the outcome. At worst, this limited emphasis simply reinforces and reiterates the ideological change it attempts to explain and lacks a sociological variable due to the inevitability of the technology progression.

In other scholarly literature, human agency is equated with the spread of neoliberal ideology, rather than corporate power and influence. Often in these arguments, the presidency of Ronald Reagan is used as a transition point to demarcate the triumph of a particular neoliberal ideological orientation. In this way a primary driving factor for the transition to neoliberalism is simply Reagan's personal belief in lack of 
regulation. This perspective is used to explain the preponderance of anti-regulators in the Department of Justice and the Antitrust Division. Ultimately, this variable places too much emphasis on the static policy of the presidency and is thus weak at explaining change in policy within the presidency as well as explaining how and why any change took place, other than the election of Reagan himself.

To better account for human agency, I will use corporate power as the independent variable. This will include three elements. The first is the direct lobbying power of corporations and their ability to shape government policies. The second is corporate collusion both within the industry and without. Within the industry, this is heavily done with the MPAA and its cartel-like activity. Outside the industry there are various levels of trade associations active in copyright and IP industries as well as the general corporate push for neoliberal policy across a wide range of sectors. Finally, there is the development of a global economy that granted corporate mobility. This was done by a transnational coalition of corporations and states that used a combination of market and political power to expand their global reach.

To help account for the problems mentioned, I will primarily use a process tracing method. While still focusing on the independent variable of corporate power, this method will allow me to better understand and explain the level of complexity inherent to such a large shift in the economic system. The need to understand the nuances and details of this shift is also the reason for using this one case study as opposed to a broader approach, which would cover the entire economy.

The motion picture industry is a relatively small political player when compared to the economy as a whole, as well as in comparison to the much larger tech and pharmaceutical companies. Despite this the film industry went through the same general process of monopolization in the 1980's. The reasons for choosing a detailed study on 
this specific industry are two-fold. First, much has already been written on the general shift of the economy. This broad examination of neoliberalism is quite over-saturated, and thus more difficult to draw out new theories. Second, by taking such a macro approach this method requires a large degree of generalization in order to examine an entire economic trend at once. While this can help explain and detail some of the major aspects of the neoliberal shift, it is poor at revealing unique details and inherently limits the role of specific actors.

Examining a specific case study will not only reveal more details of how neoliberalism affects the industry in question, but it will also offer more details and analysis pertaining to neoliberalism itself. The generalizations required to examine an entire economy or process would inherently exclude relationships which are unique to specific industries. While these are arguably the most important components, they are not the only ones. Causal variables that are only related to some industries are still inherent components to the broader topic of neoliberalism. An example of this is the increased protection of IP after the 1980's. While not all industries rely on these new related laws, it can still be argued that not only are they an outcome of the neoliberal shift, but a required and inherent causal mechanism as well. More specifically to the motion picture industry are copyright laws, which are a smaller subsection of IP. This case study will examine the role of political power in the Motion Picture Industry, including the political factors contributing to monopolization in that industry. Examined as a case study in the context of broader trends, I will reveal how this process has evolved nationwide and how the motion picture industry itself was one of many instrumental actors to spread neoliberal policies.

As a result, the method of process tracing and historical narrative becomes exceptionally important. The case study is capable of being a single case in both a 
small-N and Large- $\mathrm{N}$ generalized study. In addition, the case itself can reveal details unique to itself, those generalizable to similar cases, and finally those generalizable to a broad, Large-N study. While analysis of specific variable relationships assists in structuring the research design, process tracing and narrative methods will bring the specific causal relationship to a broader understanding of theory and the real world. As mentioned the literature tends to focus too closely on specific independent variables of technology and ideology. As a result, the conclusions are limited to the specific industry or generally weak or overemphasized in causation. A deductive process tracing method, however, can better reveal both the applicability of findings to other cases as well as the relationship that the specific variable has to the broader generalizable cases, which in this case are the economy and neoliberalism (George \& Bennett, 2005).

Utilization of process tracing and individual case studies thus allows for "finegrained description," but also more generalizable "concept formation" (Della Porta, 2008, pp. 211). By allowing for a more complex understanding of causation, process tracing and case studies can take a more deductive approach, which allows for developing and testing theories (Della Porta, 2008, pp. 211). This is the opposite of Large-N approaches, whose research design may be informed by theory, but has trouble explaining the complex details that allow for a more complex understanding of causation.

The utility of this can be seen in Bachelard's first epistemological acts (Della Porta, 2008, pp. 229). The first act, "the rupture with conventional wisdom," relates to differing methods and variables from the existing literature discussed above (Della Porta, 2008, pp.229). This step relates to the deductive utilization of existing theories. The second act, "theory construction," is what turns a historical narrative into process 
tracing, "converting historical information into a suitable analytical vocabulary that can be applied to other cases" (Della Porta, 2008, pp. 230).

As a result of details and general theory that can be derived, process tracing will provide a clearer understanding of the causes and outcomes of the film industry restructuring. As opposed to relying on structural variables such as technology and ideology, this approach will properly examine the relationship between actors and the structure, and how the structure is altered. More specifically, it will examine how the Major Studios were instrumental in shaping politics, policy, and the market.

Politically, this will show how the Majors were politically active, both individually and through multiple and overlapping trade associations. The success of this lobbying will be shown by referencing policy outcomes beneficial to the Majors, as well as direct political connections. This in turn contributes to the change in the market, whereby the Majors are legally allowed to dominate distribution by vertical monopolization. The nature of both studios and film are altered as production, advertising, and amortization time of profits increase. The economic and political power of the Majors were mutually reinforcing and allowed influence into the national arena by promoting and protecting a transnational reach in political influence and market dominance.

\section{Chapter outline}

This dissertation will be organized along the following lines. Chapter 2 will expand on the historical foundations mentioned above and the re-development of the film industry oligopoly into the 1980s. While similar to the foundations of the historical monopoly and oligopoly, the modern form will be examined within the neoliberal system. During this time period, corporate power becomes more dispersed around multiple avenues of vertical monopolization. For the Major Studios this means being incorporated 
into Mass Media Conglomerates (Holt, 2011), which make film one iteration of media intellectual property. The industry itself becomes centralized around several competitive areas, whose reach becomes exclusive to the Major studios of the oligopoly: 1) financialization of the industry, around blockbuster budget inflation, advertisement costs, and financing of smaller co-productions; 2) a centralization of intellectual property, which assures consumer familiarity and thus likeliness of viewership, allows for integration into other forms of media (television, video games, toys, etc.), and allows for longer amortization of production budget investments; 3) a wider control of distribution, away from theaters and to broadcast, cable, and online streaming.

Chapter 3 will then examine how corporate power of the Majors expanded internationally, which resulted in the creation of a multinational oligopoly. Internationally the Majors have a history of stronger cartel-like collusion, which has only been exacerbated with industry concentration, globalization, and more avenues to affect policies, such as through trade agreements. This chapter will also examine the political effect the MPAA has had on societies and the international system, which is especially important for the Majors as media companies.

With the neoliberalization of the industry complete and oligopoly cartel redeveloped, chapter 4 will examine a major effect of concentrated political and economic power. Beyond allowance of monopolization, this will reveal the development of active state support to corporations in the style of a subsidization system. While this is done in numerous industries, the Major Studios provide a more blatant and egregious example, compared to others that are more complex or hidden. This chapter will examine how the Majors utilized early transnationalization with the Canadian market for US states and Canadian provinces to compete for film production through direct and indirect subsidization. Once this norm was set it was expanded first to the European 
market to today comprising numerous states all around the globe. These states compete for the Majors' productions for domestic jobs and investment by subsidizing blockbusters up to $30 \%$ of budget costs, or even more.

Chapter 5 will examine the next iteration and effect of power concentration through less-often examined issues. This will focus on how a cartel like the MPAA is about to develop strong international coalitions, which assist in developing the international neoliberal system, described in the preceding chapters. These coalitions are a mixture of trade associations, corporations, politicians, and governments that participate in shaping regulation, laws, norms, and ultimately society. The focus of this chapter will be on the well-known, but poorly analyzed Federation Against Copyright Theft (FACT) organizations and corresponding networks. These organizations were transnational coalitions between the MPAA and local partner studios and corporations, to influence foreign governments, set copyright enforcement, and legal norms, and use the broader coalition to push them to neighboring states and regions. These organizations started with markets first dominated by the Majors in the Anglo world: the US, Canada, the UK, and Australia. The Majors used their power within these countries as a base from which to shape broader European legal norms. Now the Majors are currently attempting to expand their political and economic power to the broader Asian market.

Finally, I will conclude by relating the film industry to broader trends in the economy and society. This will first focus on the continuation of concentration within the industry, as well as the growth and overlap of media conglomerates into other industries and sectors. This will mean larger oligopolies and competition focused around monopolization of sectors and industries, especially as growing competition for the Majors is coming from tech giants, such as Google and Amazon. I will then examine the 
political implications, as well as foreign policy issues, as the Majors continue to monopolize and dominate new markets with the support of Washington. I will then examine solutions that go beyond simply antitrust regulation, that will end collusion between private interest and state capture, while necessarily reshaping international rules and institutions to re-empower democratic societies over corporate monopolies. 


\section{Development of Mass Media Conglomerates}

This chapter will examine how common tools of corporate and cartel power are adopted and expanded into the neoliberal economy. I will first look at the development and structure of the Mass Media Conglomerates, of which film production comprises only one sector, but of which the MPAA--nominally only for film--acts as an essential institution for cartel cohesion of the media industry generally. With Mass Media Conglomerates covering industries such as television, music, news, print, and other entertainment, including film, traditional barriers of entry to competing with the oligopoly are modernized and extended. These are financial, intellectual property, and distribution control, all of which had been utilized in some manner as early as the MPPC in 1908. This chapter will cover how these barriers are applied today, to the benefit of the oligopoly, focusing on the numerous forms of distribution and exhibition along with the centrality of the Blockbuster form of film, with high-return, high-budget, expensivepromotion, and increasing reliance on Intellectual property for risk reduction. The important point that will be emphasized is that competition exists between the major studios utilizing sector control and Blockbuster production, but this manner of competition reinforces the oligopoly rather than combats it. Producers and studios outside of the oligopoly's barrier find themselves dependent on the whims of the Majors. Finally, this chapter will examine the political relations and effects of this cartel.

\section{Mass Media Conglomerates}

Although the MPAA and its members took advantage of the deregulatory environment in the 1980s to restore their oligopoly, they also played a key role in tandem with other leading corporations in pursuing and determining how that deregulation would unfold. The corporate-state relationship that would develop out of this would form the 
foundation of the neoliberal system under Reagan. Far from the simple claim of deregulation, under neoliberalism corporations would find state support for extending market share through internationalization, extending intellectual property protection, and subduing labor power. Such an environment tended to benefit specific industries as well as specific corporations, which were large enough to rely on political ties, overcome growing barriers to entry, and specialize in products whose value was immaterial, easily internationalizable, and liquid and financializable. With film and copyright meeting these requirements, the MPAA successfully leveraged their growing political influence to shore up their industry barriers. New and old media were concentrated into single corporations, bringing film and other entertainment together. The new Mass Media Conglomerates increasingly focused on intellectual property (Prince, 2000) rather than film, music, or novels as their own artistic medium. Increasingly representing media at large, rather than only film, the political influence of the MPAA would grow exponentially, as the state looked to depoliticize and tacitly corporatize the growing complex questions over technology.

Importantly, the return of monopolization was not the result of a major change in law, but rather a change in the relationship between government and corporation. While a single company may not dominate one industry or sector, under neoliberalism they are able to operate in numerous sectors simultaneously. For the film industry, this was a direct reversal of the Paramount Decree. Like the 1930s, studios could now own theaters, along with new exhibition sectors that had been developed since then, such as broadcast, cable, and video. Also like the 1930s, no single company monopolized a sector, but influence, or even dominance, of one sector would have large effects on another. However, unlike the 1930s and '40s lead up to the Paramount Decree with clear delineation of production, distribution and exhibition (theaters), the multitude of 
interconnected sectors and technologies under neoliberalism adds greater complexity. In fact, the growing complexity provided much of the pretext to depoliticize and tacitly corporatize, by leaving the existing oligopolies to manage many growing technological issues.

The consolidation of media sectors and vertical monopolization are analogous to the incorporation of the Major Studios into Mass Media Conglomerates (MMC). MMCs are media corporations that take heavy advantage of the ability to invest in all, or nearly all, media sectors. Today these include broadcast TV, cable, satellite, home video (today Blu-Ray), and streaming services but also semi-related industries such as print, music, toys, and even theme parks (Prince, 2000). The reason for such media concentration is about synergy of a product, as many of the sectors are simply exhibition points of film and television, while others offer different iterations of the product, such as Harry Potter World at Universal Studios. While synergy implies an efficiency from concentrating the industry, it ignores the power and control this affords the MMC by expanding the centrality of intellectual property. It is the strength and extension of intellectual property that synergizes the product through its iterations. In other words, smaller studios which cannot produce toys from their film will have difficulty competing with those who do, even only in film.

The MMCs themselves were first formed starting in the 1980s, with loosened antitrust and a purchase of a Major Studio (see parent company chart). While the film studios are the official members to the MPAA, rather than the conglomerate parent company, it still functions as a centralizing institution for the MMC oligopoly, if not copyright and intellectual property industries generally. ${ }^{12}$ This is due to the MPAA

\footnotetext{
${ }^{12}$ While there are numerous organizations playing a role for such interests, few are so international, publicly engaged, and exclusive in membership as the MPAA.
} 
having a long history and institutional culture, but also thanks to film playing a central role in intellectual property as a media product. The MMCs use ownership of blockbuster films to provide initial cultural impact, as well as gauge how much investment to put into other sectors, such as producing television, video games, or theme parks. As sector investment plays a major role not only in the structure of MMCs, but the utility of blockbusters, the next section will focus on that consolidation, followed by blockbuster financialization.

\section{Parent Companies}

\begin{tabular}{|l|l|l|}
\hline Film Studio & Parent Media Conglomerate & Year Conglomerate \\
& & Formed \\
\hline 20th Century Fox & 21st Century Fox (News Corporation) & $1985^{13}$ \\
\hline Universal & Comcast & $2011^{14}$ \\
\hline Columbia Pictures & Sony & 1989 \\
\hline Paramount & Viacom & 1994 \\
\hline Warner Bros & Time Warner & $1990^{15}$ \\
\hline
\end{tabular}

${ }^{13}$ Recently purchased by industry leader, The Walt Disney Company. This narrows competition within the oligopoly to five, with Disney taking a strong market share in many sectors.

${ }^{14}$ Although one of the latter purchases, Universal Studios was purchased by Japanese technology company Matsushita in 1990, following Sony's example. It was then passed to Seagram, Vivendi, and General Electric, before ending up under Comcast, thus bringing Internet Service Providers into Media Conglomerates.

${ }^{15}$ Following Comcast, Time Warner (now Warner Media) was purchased by AT\&T in 2018, increasing concerns of the incorporation of home and mobile internet will be incorporated into media conglomerates. 


\begin{tabular}{|l|l|l|}
\hline $\begin{array}{l}\text { Walt Disney } \\
\text { Studios }\end{array}$ & The Walt Disney Company & $1986^{16}$ \\
\hline
\end{tabular}

\section{Sectors}

Most telling of the neoliberal approach to antitrust for film was the end of the Paramount Decree in the 1980s. As covered in the previous chapter, the Paramount Decree was a means to limit Major Studios' hold of the industry by ending their control on the exhibition of films--deciding which films are shown in theaters. The Decree had done this by barring ownership of production companies and theaters, ${ }^{17}$ and was the single largest blow to the film oligopoly. The clear end came when TriStar Pictures ${ }^{18}$ purchased Loews Theaters in 1985 and MCA Universal purchased Cineplex in 1986. While these initial purchases were expected considering the shock to the oligopoly in 1948, the interest in theater ownership did not last for the Major Studios. In part this is due to the decline in theater importance to film revenue. In 1948 theaters naturally made up $100 \%$ of film revenue, while by 1985 it was only $25 \%$ (Vogel, 2014; see chart). Nonetheless, success in theaters was still essential to revenue from other sectors as well, such as from cable or broadcast release. While the dispersal of revenue explains

\footnotetext{
${ }^{16}$ Walt Disney Studios was renamed The Walt Disney Company in 1986, but was already effectively a Mass Media Conglomerate long before the others were formed, with a focus on production, theme parks and toys. The change of name from "Studios" to "Company" is in line with its further conglomerization, such as purchasing broadcast and cable networks. Disney only joined the MPAA in 1979.

17 Though Production and Distribution (how film made its way to theaters) was retained in many of the same Studios.

${ }^{18}$ TriStar Pictures, founded in 1982, was already an indication for loosening regulation. Owned by Columbia Pictures, HBO, and CBS the studio was already blurring the lines between production and exhibition.
} 
part of the disinterest in repurchasing studios, it can thus not explain it all. Rather, control of a sector no longer requires outright ownership, as can be seen in how theater control is managed.

\section{Film Industry Revenue Sources: 1948-2007}

\begin{tabular}{lllccc}
\hline \hline Year & Theater & Video/DVD & TV $^{a}$ & Total & $\begin{array}{c}\text { Theater } \\
\text { share (\%) }\end{array}$ \\
\hline 1948 & 8.5 & $-0-$ & $-0-$ & 8.5 & 100.0 \\
1980 & 4.9 & 2.2 & 4.1 & 9.2 & 53.3 \\
1985 & 3.3 & 2.6 & 7.4 & 13.3 & 24.8 \\
1990 & 6.8 & 6.5 & 10.1 & 22.4 & 30.4 \\
1995 & 6.2 & 11.9 & 11.6 & 29.7 & 20.9 \\
2000 & 6.5 & 13.1 & 15.5 & 35.1 & 18.5 \\
2005 & 7.0 & 22.6 & 16.9 & 46.5 & 15.1 \\
2007 & 8.8 & 17.9 & 16.2 & 42.9 & 20.5 \\
\hline \hline
\end{tabular}

Note: In billions of 2004 dollars, free TV was $\$ 3.35$ in 1980, $\$ 5.74$ in 1985, $\$ 7.6$ in 1990 , $\$ 8.13$ in 1995, $\$ 11.03$ in 2000, and $\$ 12.60$ in 2005 .

${ }^{a}$ Includes both PPV and subscription pay-TV and free TV (networks, cable, and local stations).

Vogel (2014, pp. 98)

\section{Theater Control}

Even during the so-called "Golden Age" of film studios in the 1930s and "40s, major studios that leveraged control over theaters did not monopolize the entire sector through outright ownership. Rather than owning a majority of theaters, the Majors focused on first-run theaters. As the name implies, these were theaters to first run a film stock, after which it would be transported to second-run theaters and so forth, rather than printing costly film for each theater. First-run theaters were thus able to heavily determine not only which films started the circuit, but also which films caught notoriety and piqued consumer's interest. Independent theaters, which were the majority, needed 
to fulfill demand and show the films set by the first run theaters ${ }^{19}$ (Seabury, 1926). This is true today as well, but even more dispersed through technology and an increased number of exhibition sectors. This retains control and the barriers oligopolies need, but also provides the flexibility neoliberalism and globalization demand. As will be seen, indie production operates on a similar junior partnership relation as well, filling in space that the Majors cannot (especially for less limited exhibition such as home video and streaming). In all cases, the Majors, rather than looking at literal monopoly, looked toward creating and exploiting bottlenecked sectors. ${ }^{20}$

To counter this, theaters have also attempted their own concentration to offset the leverage of powerful studios. Two of the major chains are AMC Theaters and Regal Entertainment, who together have created their own production studio called Open Road Films (now Global Road Entertainment). Also illustrative of this is that Cineplex and Loews were eventually merged to stave off losses, before going bankrupt in 2001. Much of the difficulty for theaters is specifically the leverage that Major Studios have on profit sharing terms, driving many theaters to focus on profits from concessions rather than exhibiting film. ${ }^{21}$ Today studio behemoth Disney is pushing even more onerous terms on theaters than already existed, in order to leverage the power of film IP owned by the company. This is increasing the revenue split, the minimum length of showing the film, and requiring films such as Star Wars to be shown in the best theaters. By 2007, the

\footnotetext{
${ }^{19}$ This is on top of other controlling practices, such as blind and block booking, which were also largely barred in the Paramount Decree.

20 Thurman Arnold, Assistant Attorney General for Antitrust under Franklin Roosevelt, lamented that antitrust was not as extensive as he wished, worrying about areas that leading corporations can still create these industry "bottlenecks" (Arnold, 2000).

${ }^{21}$ This is especially true for the initial release of blockbusters where the profit share is heavily in favor of the studio (Epstein, 2006), with up to $90 \%$ of box office proceeds going to Major Studios for initial release.
} 
Majors' revenue was $\$ 42$ Billion. Only 10\% came from American theaters (Epstein, 2012).

This is, however, not due to absolute shrinkage of the sector, with revenue recently recovering to its high point (See figure above). Nonetheless, theaters are now only one sector of one iteration of the Major Studio's IP, which helps explain why they have not been reincorporated. Nonetheless, the monopolization of the sector continues on its own. Epstein (2012) says $80 \%$ of Major's box office share came from a few megaplexes. Of the 40,000 screens in the U.S., half are owned by the three largest theater chains: AMC, Regal, and Cinemark (National Association of Theatre Owners). While this oligopolization is a trend within neoliberalism, it also may be part of dealing with the more powerful Major Studios, whose blockbusters are essential to a theater's success. Studios cannot demand screen access from theaters on the condition of future films, but "they have considerable tacit leverage, since the theater chains depend on them to favor them with major blockbusters. As a result, the big studios almost always get the screens they need for their openings" (Epstein, 2006, pp. 189). As studios were incorporated through film and IP "throw weight," the remaining exhibition sectors have been much more integrated directly into the MMCs.

\section{Blockbusters}

Blockbusters are commonly thought to have started with the 1975 film Jaws. The term blockbuster was taken from films that bring so many customers to the cinema that the line will exceed the block. Although having a budget of \$8 million, Jaws brought in $\$ 250$ million domestically and half a billion worldwide..$^{22}$ Studios that were able to replicate this model boosted the production value of their films. This helped the Majors

22 This makes Jaws one of the highest grossing films of all time, when considering inflation. 
reclaim much of their market share by the end of the 1970s (see chart below), and evolved into a requirement to compete on the Majors' level. The decline in absolute number of releases of the Majors since the 1990s reveals this greater concentration and focus on fewer, but larger, more expensive, and more advertised blockbusters. As this practice inflated film budgets to ever higher numbers, the political economy of the Major Studios has coalesced around reducing risk ${ }^{23}$. For Blockbusters directly, this risk reduction comes in the form of intellectual property, franchising, advertisements, and financialization.

\section{Major Studios' Domestic Market Share (Cook, 2000, pp. 492)}

\begin{tabular}{|lrrrrrrrrrrr|}
\hline & 1970 & 1971 & 1972 & 1973 & 1974 & 1975 & 1976 & 1977 & 1978 & 1979 \\
\hline American International & na & na & na & na & 3.8 & 3.4 & 3.8 & 3.4 & 1.4 & 2.8 \\
Buena Vista (Disney) & 9.1 & 8.0 & 5.0 & 6.5 & 7.0 & 6.0 & 6.7 & 5.6 & 4.8 & 6.2 \\
Columbia & 14.1 & 10.2 & 9.1 & 7.0 & 7.0 & 13.1 & 8.3 & 11.5 & 11.6 & 14.0 \\
MGM & 3.4 & 9.3 & 6.0 & 4.6 &.-- &.-- & $\ldots-$. & $\ldots$. & $\ldots .$. & $\ldots .$. \\
Paramount & 11.8 & 17.0 & 21.6 & 8.6 & 10.0 & 11.3 & 9.6 & 10.0 & 23.8 & 16.0 \\
20th Century-Fox & 19.4 & 11.5 & 9.1 & 18.8 & 10.9 & 14.0 & 13.4 & 19.5 & 13.4 & 16.0 \\
United Artists & 8.7 & 7.4 & 15.0 & 10.7 & 8.5 & 10.7 & 16.2 & 17.8 & 10.3 & 7.0 \\
Universal & 13.1 & 5.2 & 5.0 & 10.0 & 18.6 & 25.1 & 13.0 & 11.5 & 16.8 & 20.0 \\
Warner Bros. & 5.3 & 9.3 & 17.6 & 16.4 & 23.2 & 9.1 & 18.0 & 13.7 & 13.2 & 14.0 \\
All others & 15.3 & 22.1 & 11.6 & 17.4 & 11.0 & 7.3 & 11.0 & 7.0 & 4.7 & 4.0 \\
\hline \multicolumn{1}{c}{ Total } & 100.2 & 100.0 & 100.0 & 100.0 & 100.0 & 100.0 & 100.0 & 100.0 & 100.0 & 100.0 \\
& & & & & & & & & & \\
Source: Variety reports. & & & & & & & & & & \\
\hline
\end{tabular}

Major American Distributors' Domestic Market Shares (1970-79).

This interrelated change in the product, and corresponding need for longer copyright, relates to the structure of longer amortization and new ancillary markets. This

\footnotetext{
${ }^{23}$ This risk/requirement can be seen in one of the earlier attempts at a blockbuster. Released in 1980 Heaven's Gate effectively ended United Artists, rather than potentially elevate them out of the "Mini-Major" status. Bridging director autonomy and high production, Heaven's Gate went over budget several fold, without corresponding box office success. While Jaws marked the birth of the blockbuster, Heaven's Gate marked the end of what Biskind (1999) called New Hollywood-director and art driven films missing corporate hierarchy, and the potential for compatibility of the two.
} 
was, as Prince (2000) argues, the transition from film as a product, to just one iteration of an intellectual property. This change came with the high cost (budget inflation) of blockbusters and the corresponding need for cultural saturation, helped along by growing advertising campaigns. These campaigns also increased in costs, as a blockbuster success could lead to new iterations to profit off their intellectual property-be it a story, a character, a created universe, or simply a sequel that will be more likely to be a blockbuster itself. As a result, antitrust relaxation, sector monopolization, and blockbuster focus all become interrelated. The iteration and reiteration to reach all ancillary markets became the norm as all profitable films focused on franchising, or at least cashing out a sequel. This has even resulted in the sequel to the classic Disney film Bambi, with Bambi II profiting on the cultural importance of the original, coming out in a record 64 years later, in 2006 . Thanks to more markets, a greater role for indies (as majors focus on IP distribution and finance), and more funding from Wall Street, the number of films produced exploded in the 1980s (Holt, 2011), contributing to the reshaping of the industry.

The result is that in today's film culture, the most popular and thus highest grossing films are usually from existing franchises or have been developed into iterations. For the highest grossing films of all times one can view three general categories: 1) produced and released prior to the 1970s, which is the strongest antibiotic against reiterations; 2) produced and released in the decades from the 1970 s to the 1990s, which are commonly utilized for iterations or franchising; and 3) made since the 2000s, which are commonly iteration or part of a franchise. Of the 100 highest grossing films (accounting for inflation) 24 were made after the year 2000. Of this 24,22 were not original, either being a sequel, episodic (such as Lord of the Rings), or part of a larger IP "universe" (such as the Spiderman films). Of the two films that were original one was 
Finding Nemo (2003), which had a sequel released in 2016 (which was itself the 72rd highest grossing film of all time: Finding Dory) and was franchised by Disney. The only other modern film with an original story to be a top grosser is The Passion of the Christ (2004), whose original material luckily predates copyright.

The centrality of blockbusters to operate as tent poles (primary revenue generators) for Majors is only one element that heightens the barrier to entry for Major competition. They also play an essential role that helps necessitate and reinforce the other means of power. While size of media conglomerates, market reach, and ownership of exhibition sectors are in themselves empowering, the particularities of a cultural product require what has become dominant film brands/franchises. Film is a highly replaceable good, not only in the sense of replacing one movie with another, but also as replacing viewership with another form of entertainment. As such, to avoid the fragmentation of the industry into, intuitively one might assume, numerous small-end niche films, the Majors have inundated society to a normalization of a product they can better control. Like other industries entering neoliberalism, this meant a move away from control of physical production (such as camera patents or "Fordist" factory style of films) to more intangible additions of value.

As reiterated throughout these chapters, this growth of neoliberal forms of competition compounds what has already been a very centralized industry. Robert Brady has said that there is "probably no other commodity or service sold in America that lends itself so easily to the exercise of monopoly control as do the products of the movie industry" (1947, pp.131). This change, as well as general adoption of neoliberalism, increases all six of the natural advantages Brady lists for the Majors: 1) movie stars who offer a unique drawing and whom the major studios can dominate via employment. 2) uniqueness of individual film narratives. 3) quality that requires heavy capital 
investments. 4) perishability of the film in order to create high turn-over-a quality heavily controlled by the major studios. 5) copyright protection, and 6) ownership of theaters (multiple exhibition streams for modern industry).

Balancing expensive, star-studded films, which also had to be differentiated and "perishable" to consistently bring in viewers, brought in greater reliance on the exhibition streams and copyright protection. As a result, the evolution of the film industry within neoliberalism has attained the best means of providing these seemingly contradictory but necessary elements. This is the need for high turnover and ability for films to become "stale" and thus constantly generate demand for new films, while also retaining the popularity that directs moviegoers away from other films. Connected to this is the extension of intellectual property, both for direct film value, as well as ability to amortize the film into other revenue streams and products. The reliance on franchises, sequels, and episodic films is what has allowed for this modern utilization of blockbusters, which itself is dependent on the growth of intellectual property, to become a core trend in the broader neoliberal political economy.

As a result, the elements that are increasing the cost of production budgets are the same that are creating a barrier to compete at the Majors' level. The high costs of sets, location shooting, stars, franchises, intellectual property, and advertisement is outside the means of most indie studios, leaving competition largely between the Major studios themselves. The means of amortizing the growing cost of film and associated intellectual property are additional means of barrier and dependency--the international control of distribution and exhibition. As a result, the higher cost of blockbuster films that should increase risk due to being a larger investment, is mitigated by reshaping the industry around MMCs, intellectual property, and numerous ancillary markets. That is to say, the higher risk in inflated budgets of blockbusters is mitigated by the very oligarchic 
structure it reinforces. In the end, the Major studios ultimately compete only amongst themselves and a single "Mini-Major."24

The industry was also reshaped by its internationalization of both production and distribution, which was required to decrease labor costs and location shooting as well as provide a larger market for revenue (See Chart Below). For example, the purchase of Lucasfilm by Disney for $\$ 4$ billion, on top of the cost for individual films in the hundreds of millions, needs to be offset by a large, international market. On top of affecting the industry structure, the increasing focus on international markets has also changed how narratives are presented in leading films. Contrary to the dialogue-laden films of the Golden Age, today films' focus on teenagers, foreign markets, and a broad audience, which makes competition about creating a spectacle (called lowest common denominator by some) and familiarity. Because films are highly replaceable with one another, having the same ticket prices, films need to bring in viewers away from other films, rather than trying to generate a larger market. As a result, on top of the spectacle of expensive CGI and action, the increasingly multi-generational aspect of intellectual property makes these films cultural and even socially important for people to view. In contrast to idiosyncratic interests, one "keeps up with the Skywalkers" to fit in socially. ${ }^{25}$

\footnotetext{
${ }^{24}$ Lionsgate. See more below.

${ }^{25}$ Star Wars was able to generate a large, if semi-niche fan base immediately, another popular franchise, Star Trek, has seen recent film remakes that drive more to the spectacle. The Studio in charge (Paramount/Viacom) has a history of focusing on story and character simplification in favor of CGI and action. While this may appeal to some, usually teenagers according to the target audience, it has a diminutive effect on those with idiosyncratic and niche interests. The result is seemingly hyperbolic or melodramatic claims of "betrayal" of the fans, who themselves help shape the franchise into a cultural icon.
} 


\section{Domestic and International Box Office Revenue for Major Studios}

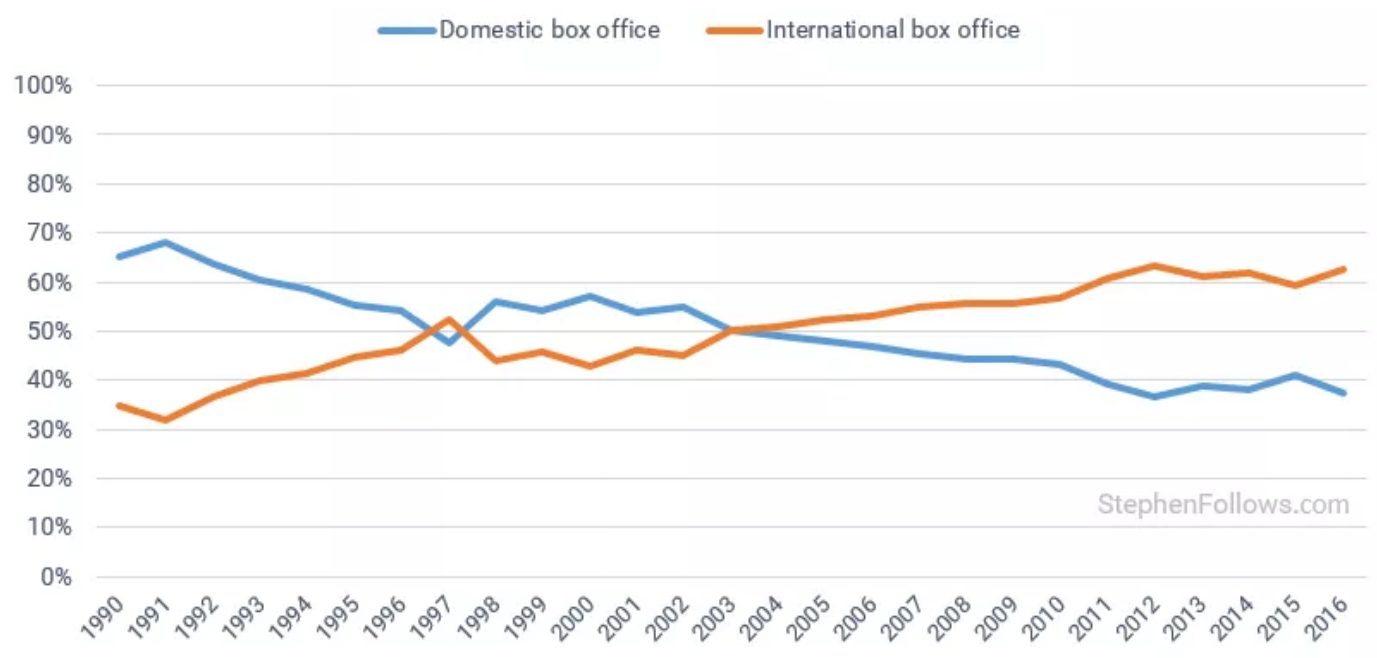

Follows (May 15, 2017)

All of these elements result in a compounding need for Majors to focus on purchasing or developing lasting IP franchises. This is based off a formula of culture, cost, amortize, and spectacle: 1) the need to compete based on the well-known and familiar rather than price, artistic merit, and lesser reliance on expensive advertising campaigns. This includes utilizing popular IP as a barrier to entry; 2) the inflation of blockbuster budgets that allow "major" competition that requires assured ticket sales; 3 ) the need to utilize and fill the numerous exhibition streams, which are used to amortize the high budgets of the previous point; 4) generate a uniqueness to a film to attract moviegoers from other films and concurrently provide a "common denominator" attraction, not only for the largest audience possible, but also for an international audience with differing languages, cultures, and histories. Thus, franchises allow for a "value-added" spectacle, making a film that is at the same time unique and standardized, perishable and amortizable, and expensive and safe. 
As a result, to compete at the Major level studios are required to either create or purchase leading intellectual property. While there has always been a utilization of existing IP, such as from books to create the plot of films, the important components here are the exclusivity through copyright and trademark, and the franchisability. This results not only in consistent modern reproductions--reboots, remakes, sequels, and prequels-- of past popular films, but a serialization through leading franchises. While one-off remakes usually of popular movies in the studio's library can reduce the risk of production costs, it is the popular franchises that assure a continuous and stable profit for the blockbuster risks of the majors. This is again due to the amortization of these franchises through the numerous sectors that the Majors own, but also due to the cultural popularity of these franchises. As a result, many of the most successful franchises of the Majors are not created, but acquired either from other film studios (Star Wars and Shrek) or from popular literature (Harry Potter and Marvel and DC Superheroes).

While Finding Nemo found its franchise all within the new millennium, this trend is also seen in a new generation of remakes. With a record 64 years following the release of the original, Bambi I/ (2006) is probably the most absurd example. While Bambi may remain a cultural icon, it is still the culturally inundating and franchisable films that are needed. These are able to assure viewership due to episodic releases and can easily be extended into the numerous exhibition sectors. This effectively takes the risk associated with high budget films, but encases them in the continuity and security of television episodes. ${ }^{26}$ Again, while remakes can be released from the IP of an existing

\footnotetext{
${ }^{26}$ Interestingly, television shows themselves have changed thanks to the technology of online streaming. Rather than consistent and narratively independent episodes, seasons are now commonly released at once and with a season-long story arc. Especially on streaming platforms like Netflix, this is to generate immediate and constant viewership, rather than loyal and returning.
} 
film library, blockbuster franchises are more difficult to attain. Rather, franchises tend to follow and reinforce the cultural zeitgeist, and have greater trouble creating it. One can see this clearly in one of the largest blockbuster flops, Disney's John Carter. Despite being based on a semi-popular novel series and a massive budget of $\$ 300$ million it failed to reach its expected audience. Part of this failure is likely that it was not already a household name that held a place in culture--being a "must see" in which people expect one another to see the film. Instead, Disney found much greater success in purchasing already proven and culturally significant franchises of Marvel and Star Wars.

Universal has also faced trouble in creating a "new" franchise, as it attempts to revamp very old IP (and arguably one of the first film franchises) to create a Universal Monster "Dark Universe," with such early films such as Dracula and Frankenstein. While well known, and foundational to the very horror genre, these films do not tap into any current cultural zeitgeist as Star Wars or superheroes do. As such, the creation continuously faces setbacks as Universal faces the same high expectations, and, indeed, high success the existing barrier to entry requires. As such, reinforcing and rebooting existing successful and culturally relevant IP has seen more success. This is, in fact, the very reason that Lionsgate has been able to compete as a Mini-Major. Its franchises had been acquired through its purchase of Summit Entertainment. As a result, when Lionsgate does take in high percentages of international box office revenue it is with the three IP franchises that it relies on: Twilight, Hunger Games, and to a lesser degree Divergent.

\footnotetext{
Even traditional television has adopted this new structure (Bank et al. October 23, 2014), while film is adopting the traditional episodic structure, with reboots functioning as series.
} 


\section{Advertisement}

Along with budget inflation, advertisement has been an extremely important element that generates a barrier to blockbuster and "Major" levels of competition. Due to the relatively inelastic nature of film admissions the competition is less on the price at the box office, compared to which movie is seen. As such, films do compete with other recreation activities, but are heavily competing with what film one sees over another film. This high replaceability combined with the blockbuster budget and high cost of either purchasing or creating a film franchise, makes advertisement an essential component to the Major Studio structure. In this, blockbuster films need to be accessible, yet culturally dominant. This cultural inundation goes beyond advertising that a product exists, convincing a consumer of its superiority, or even preying upon psychological susceptibility that is prevalent within modern ads. Modern mass media advertising means creating a lasting and persistent inundation of a product that is deeply embedded in social relations--the expectation that one is familiar with certain media commodities, such as Star Wars. Thus, while blockbuster budget inflation and the cost of franchise IP increase the need for costly advertising to ensure a lasting impact on the society and customer base, they also demand increased international reach, copyright protection, and barriers against potential competition from non-Majors. With these compounding issues, it should then not be surprising that the massive growth in film budgets were not only matched, but surpassed by advertising costs as a percent of total film cost. 


\section{Advertisement Figure (Rainey, March 8 2016)}

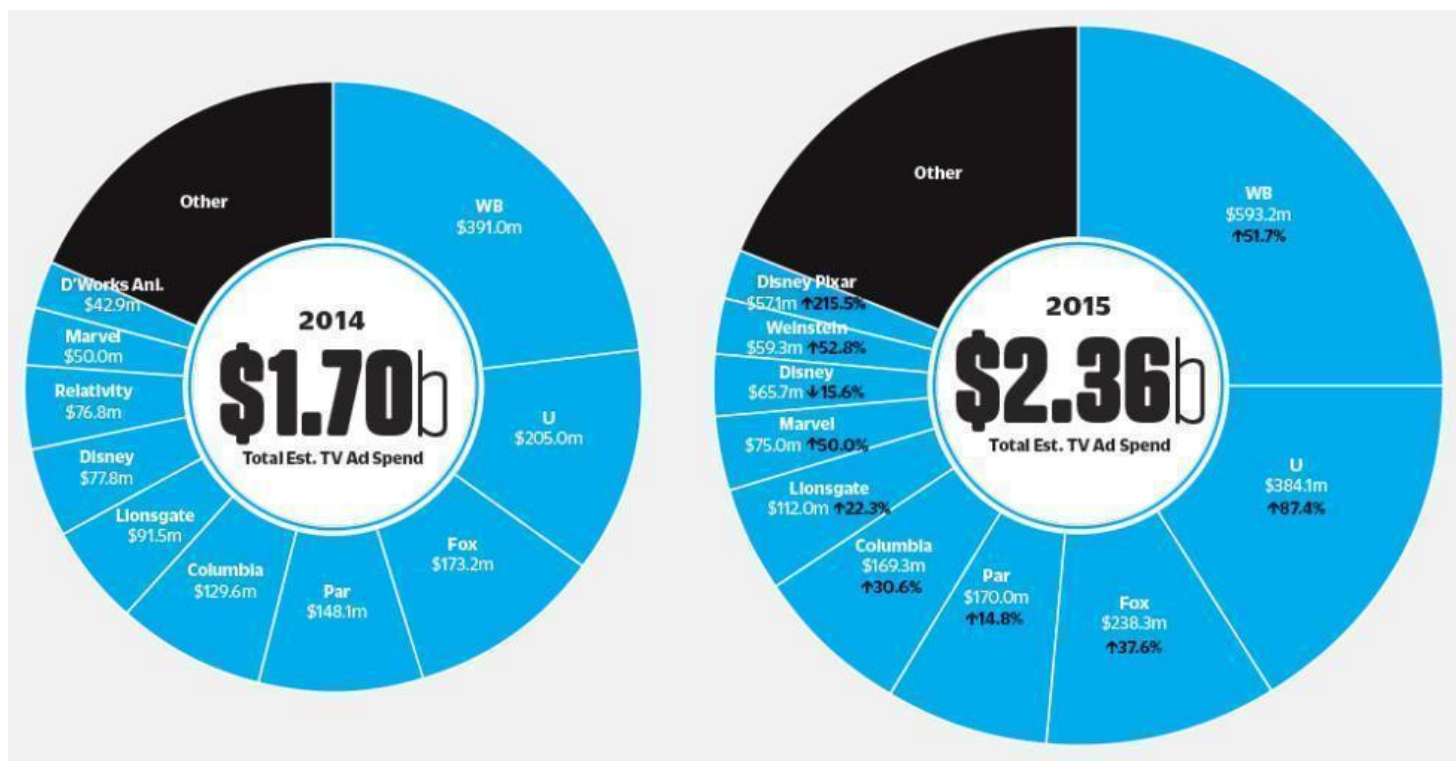

In 1997, \$19 million was the average cost per American film for advertisement campaigns (Epstein, 2012, pp. 26). In 2007 it was $\$ 35$ million on average per film (Epstein, 2012, pp. 42). According to Variety Magazine in Ad Figure, the expanded costs on TV spots for Motion Picture expanded by 39\% in just one year from 2014 to 2015. Already by 2002 , the Majors were investing “ ... nearly as much in world-wide advertising and prints as they did in making the movies themselves" (Epstein, 2006, pp. 178). This year amounted to $39 \%$ of costs were ads compared to the negatives of production ("2006 U.S. Theatrical Market Statistics"). Although this was a high period, for the period up to 2007 , when the MPAA decided to stop publishing film costs as well as advertisement spending, the cost of advertisements ran from 33-37\% of total film cost (advertising plus the physical roll of film) ("2006 U.S. Theatrical Market Statistics"). As such, this heavy advertising has been unavailable to the indie studios, not only as advertising at least keeps up with general film inflation, but also the increasing reliance 
and funding of blockbusters reaching the hundreds of millions of dollars. ${ }^{27}$ As such, the cultural relevance becomes greatly expanded, not only crowding out the limited theater admission to favor the Majors and blockbusters, but also a broader cultural crowding out, as franchises enter other distribution sectors. For indies, the ability to overcome such barriers is not only unlikely, but impossible to equally compete.

For an oligopolistic industry like Hollywood, the increase in advertisement works in the same manner. While each Mass Media Conglomerate has assured exhibition platforms, competition in audience for each sector exists, but largely among the twotiered industry. That is, the Majors tend to compete only with each other for the highest position amongst blockbusters, while leading indie studios compete with "indie subsidiaries" of the Majors, and then, finally, small producers filling up the rest. As such, as Domestic Box Office Share for MPAA films shows, the percentage the majors take in the box office is relatively stable, totaling between $90 \%-95 \%$ of leading Box Office. By contrast, the following figure shows strong change among the major studios, with Disney picking up much of Viacom's revenue. Outside of the majors, Lionsgate is again the only "indie" studio to reach a comparable market share. Including Lionsgate as the sole MiniMajor routinely leaving as little as $5 \%$ of the yearly box office to the hundreds of other films released.

${ }^{27} 39 \%$ for 2001 ; $33 \%$ for 1995 ; $28 \%$ for 1985 ( "2005 U.S. Theatrical Market Statistics") 
10. Domestic Box Office Share for MPAA films ${ }^{28}$

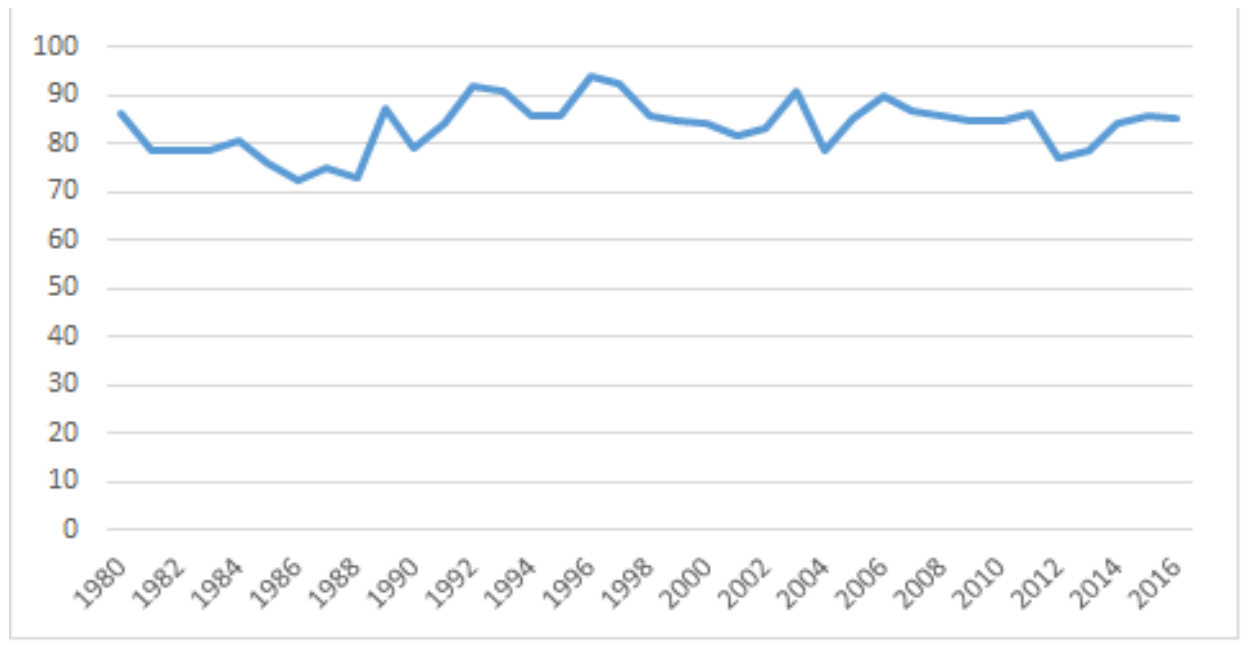

11. Domestic Box Office Share by Major Studio

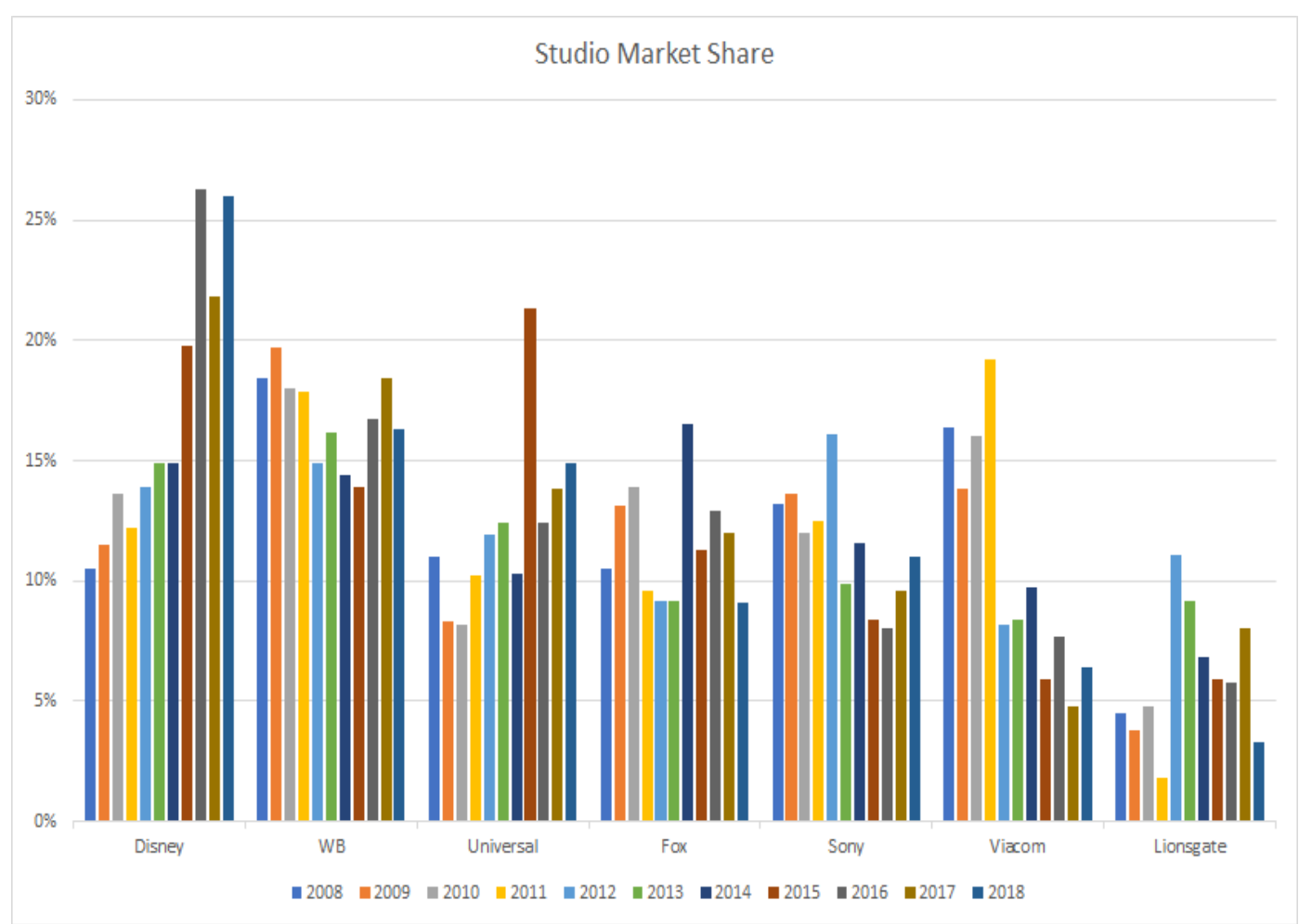

${ }^{28}$ Data from Boxofficemojo.com 
Interestingly, the use of inflated advertising campaigns as a barrier to entry can also be seen in the file-sharing issue, which adds another dimension to the MPAA's fight against piracy. For producers who cannot afford advertising campaigns, the illegal sharing of the film online can have the same effect of publicizing the film through worldof-mouth, giving smaller and relatively unknown movies more attention and, as a result, customers than if they remained without any publicity. As such, Peukert et al. (2017) found that the shutdown of popular file-sharing sites, such as Megaupload, actually led to a boxoffice decrease in smaller films, and a corresponding increase in blockbuster revenue. Blockbuster films each have their own ad campaigns, while indie films can benefit from the word-of-mouth initiated by those illegally downloading the film. Interestingly, the authors suggest sequels were largely unaffected, being already familiar to the potential audience. Again, while there has been much debate on the cost of direct film piracy there is also an undiscussed issue of how piracy affects the two-tier system within the film industry itself, with only the majors able to provide massive advertisement campaigns to direct audiences to their films and thus away from others. This relationship between advertisement, Intellectual Property, and piracy (file sharing) will be an important connection when examining the extension of copyright law and enforcement in chapter 5 .

\section{Finance}

Tied to the increasing cost of advertisement has been the longer-term problem of heavily inflated budgets. These core aspects of intellectual property and blockbusterstyle films directly tie into the general financialization of the industry. As blockbuster and "tentpole" films (using fewer leading films to generate larger revenue) became an increasingly important strategy to the oligopoly, both the cost of the films and 
popularizing them has consistently increased. As these costs soared studios could no longer simply rely on bank loans or self-financing (Holt, 2011, pp. 51), which set the ground for more complex deals from numerous actors to spread risk, which is a core corporate management strategy within financialization. Within the new production structure, it is only the Major studios (and sole Mini-Major Lionsgate) that have the ability to attract enough finance to produce such expensive films. In tandem with utilizing budget inflation to legitimize the need for concentration, sector control, and even subsidization, within the industry the Majors have been restructuring their operations to reduce cost and risk to themselves. Over time the Majors have increasingly taken on the role of "financial managers" (Cook, 2000, pp. 353 check quote) rather than direct producers and financiers. This financialized system utilized outside financing, coproduction, indie production, pre-sales to ancillary markets, distribution guarantees, and merchandising to reduce risk and centralize their position within the system (Cook, 2000).

The need for owning franchisable intellectual property and massive advertisement campaigns fits well within the argument that monopoly capital tends to compete on aspects other than price (which is quite standardized when buying or renting a film). The necessity of expensive IP accumulation and development helps drive the dividing line between the oligopoly lead firms, and the smaller indie studios, which require some degree of partnership and dependency on the majors when dealing with these greater costs. While this makes a clear delineation between major and indie film competition, it fits also well into the argument that monopoly capital has become increasingly financialized during the period of neoliberalism. This is the centralization of finance and financial products in numerous industries, as well as the dominance of financial institutions, such as Wall Street, in many industries. For the major studios, 
purchasing and developing IP, inflating production costs for blockbusters, international distribution, and advertising campaigns all constitute the financialization of the industry as well as the flexible manner of control by the majors.

\section{Indie Producers and Control}

Outside the main focus of Blockbuster productions, the Majors have set up subsidiaries to compete with lower-budget and indie films. This utilization of subsidiaries has been a tactic of the Majors since their oligopoly resurgence in the ' 80 s up to the late 2000s, whereby the strength of the oligopoly has been moving to dispense with direct ownership of mid-tier productions. Subsidiary studios, such as New Line Cinema and Focus Features (and in some cases subsidiaries of subsidiaries, such as Picturehouse and Rogue Pictures) are designed to produce less expensive films, but many times this is in an effort to reach the most profitable films (opposed to highest grossing), which are not the primary revenue generators for the Majors, but whose profits greatly exceed the cost of the film. ${ }^{29}$ While this generally did not produce a large portion of the Majors' total revenue, subsidiary studios also played an intermediate role between indies and the Majors (Scott, 2004). This created a cushion between any growing indies that could reach into the Major's market, especially early for the oligopoly resurgence, such as in the ' 90 s. As seen in the Figure below, the mid-position of subsidiaries operated between the Majors and indies, overlapping on both ends, both in production cost, but also in box office revenue. When indie studios grew in revenue and budget, they would typically compete for the mid-tier market with the subsidiary productions, rather than the Majors'

29 The most notable being Paranormal Activity which had a micro budget of $\$ 15,000$ and brought in $\$ 193$ million worldwide, giving it a return on investment rate over 1,000 times. With the cost to Paramount to acquire the rights for $\$ 350,000$, it still possessed a massive return. Despite relying on a gimmick of tiny budget, "realistic" found footage, and nothing much happening, Paranormal Activity has spawned a successful franchise in its own right. With distributor Paramount spending upwards of $\$ 17$ million for marketing for the sequel, making the ad costs multiple times the cost of the small budget film (Hampp, October 18, 2010). 
blockbusters. At times when mini-major studios became too large and began competing with the Majors, they were typically purchased by a Major studio and thus turned into a subsidiary. Two notable purchases of would-be mini-majors were Disney's purchase of Miramax in 1993, and Turner Broadcasting (which merged with Warner in 1996) purchase of New Line Cinema in 1994, which has since produced blockbusters of its own with The Lord of the Rings franchise.

12. Box Office Revenue by Studio Class (Scott, 2004, pp. 49)

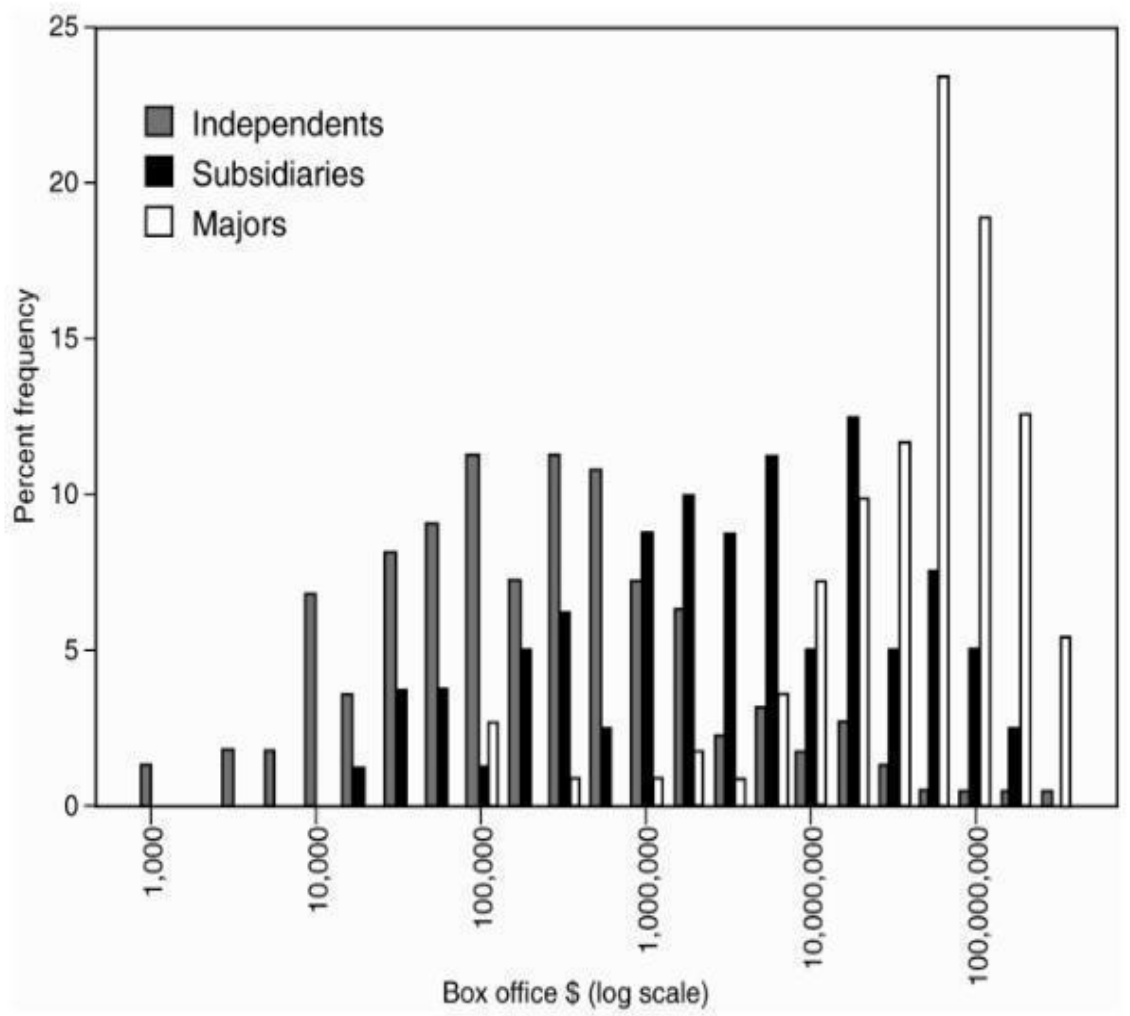

Some studios, largely Fox and Sony, have focused more on broadening their film production and having stronger competition in low-budget productions. However, in general the Majors have increasingly sought to strengthen, pursue, and occasionally create new franchises to focus on as profit "tentpoles" to stabilize profits. The Majors 
continue to operate subsidiaries to find and distribute, create, and compete with indies (See Figure below for a high point in subsidiary market share), but the Box Office gross of the subsidiaries continues to fall as a percentage of total gross, indicating the majors continue to increasingly focus on their exclusive, high-budget tier. This trend illustrates that the Major studios are more "financial managers" rather than solely production studios, or, more specifically distribution, IP, and financial managers. Thus, beyond blockbusters the focus is on distribution networks and co-productions, rather than independently owned subsidiary studios.

\section{20 most profitable studios at the Box Office for 2008 (High Point for}

\section{Subsidiaries) $)^{30}$}

1 Warner Bros.

2 Paramount

3 Sony / Columbia

$4 \quad$ Universal

$5 \quad$ 20th Century Fox

6 Buena Vista

$7 \quad$ Lionsgate

Summit

8

Entertainment

$9 \quad$ Fox Searchlight

$2.2 \%$

$18.4 \%$

$16.4 \%$

$13.2 \%$

$11.0 \%$

$10.5 \%$

$10.5 \%$

$4.5 \%$

$2.4 \%$
Mini-Major (Later purchased by Lionsgate)

${ }^{30}$ Data from Boxofficemojo.com 

10 MGM/UA
$1.7 \%$
$20 \%$ Sony and $20 \%$ Comcast
11 Focus Features
$1.4 \%$
Subsidiary (Universal)
12 Overture Films
$1.1 \%$
Indie (Starz)
13 Miramax
$0.8 \%$
Subsidiary (Disney)
Paramount
14
Vantage
$0.8 \%$
Subsidiary (Paramount)
15 Picturehouse
$0.7 \%$
Subsidiary (New Line $\rightarrow$ Warner Bros)
16 Rogue Pictures
$0.7 \%$
Subsidiary (Focus Features $\rightarrow$ Universal)
17 New Line
$0.6 \%$
Subsidiary (Warner Bros)
$18 \underline{\text { Weinstein }}$
$0.5 \%$
Indie
19 Samuel Goldwyn
$0.4 \%$
Indie
Sony Classics
$0.4 \%$
Subsidiary (Sony/Columbia)

20

While the decline of subsidiaries likely relates to greater focus on blockbusters and franchises, it also has to do with a move away from direct control to structural control by the Majors. As such, in-house subsidiaries are increasingly giving way to the Major Studios injecting their role as "financial managers" to the indie market through coproductions. This allows for the flexibility of industry control, but also allows the Majors to 
engage in indie competition without the overhead. This is especially important with the increasing globalization of film and the larger pool of small, local producers around the world. With this the Majors have been increasing their co-production financing, especially for large Studios in foreign markets, which operate as international "minimajors." This flexibility lets the studios purchase IP when necessary, develop partnership with local major studios, control transnational distribution, and compete only with one another on global blockbusters. It also helps explain the apparent decline of mini-majors, as they are now internationally dispersed and usually the leading film studio of their respective countries.

On top of spreading out costs of productions, co-producing a film develops personal relationships with studios, and many times has been the precursor to mergers or acquisitions. ${ }^{31}$ As the figure below shows, these relationships tend to stick around, rather than only forming as contractual relationships that end when a film is complete. The growth of indie-major co-productions had their start in the 1950s, but at that time was largely the result of weakness of the Majors. By contrast, today these relationships are generally predicated on the strength of the Majors as well as their global reach. The flexible management of focusing on finance and distribution allows the assurance of profits, the spread of risk, as well as the ability to meet the widening of the Majors' control to the global market.

\footnotetext{
${ }^{31}$ For example, the production company Amblin Entertainment had developed a close relationship with Universal Studios commonly co-producing films and distribution deals. Universal even eventually purchased the label spinoff from Amblin, DreamWorks Animation. Amblin continues distribution deals with Universal, and even has its headquarters on the Universal Studios lot.
} 


\section{Junior Partners and Major Studios}

Exhibit 2: Summary of recent film pacts

\begin{tabular}{|c|c|c|c|c|c|}
\hline Major Studio & \multicolumn{2}{|c|}{ Partner Studios } & Major Studio & \multicolumn{2}{|c|}{ Partner Studios } \\
\hline Sony & $\begin{array}{l}\text { Avi Arad Prods. } \\
\text { Broken Road Prods. } \\
\text { COTA Films } \\
\text { Michael De Luca } \\
\text { Escape Artists } \\
\text { Frederator } \\
\text { Gotham Group } \\
\text { Will Gluck } \\
\text { Happy Madison } \\
\text { Hey Eddie } \\
\text { Maguire Entertainment } \\
\text { Francine Maisler \& Associates } \\
\text { Laurence Mark Prods. }\end{array}$ & $\begin{array}{c}\text { Mosaic } \\
\text { Original Film } \\
\text { Our Stories } \\
\text { Overbrook Entertainment } \\
\text { Red Wagon Entertainment } \\
\text { Scott Rudin Prods. } \\
\text { Smoke House } \\
\text { Taylor Swift Prods. } \\
\text { Syco } \\
\text { TDJ Enterprises } \\
\text { Matt Tolmach } \\
\text { Trigger Street }\end{array}$ & $\begin{array}{l}\text { Fox/Fox 2000/Fox } \\
\text { Searchlight }\end{array}$ & $\begin{array}{c}\text { Bad Hat Harry Prods. } \\
\text { Davis Entertainment } \\
\text { DreamWorks Animation } \\
\text { Fei gco Entertainment } \\
\text { Film Rites } \\
\text { Genre Films } \\
\text { Giant Pictures } \\
\text { Wyck Godfrey and Marty Bowen } \\
\text { Invention Films } \\
\text { Lightstorm } \\
\text { Marc Entertainment } \\
\text { New Regency }{ }^{1} \\
\text { Hutch Parker Entertainment }\end{array}$ & $\begin{array}{c}\text { PC Film } \\
\text { R\&G Media } \\
\text { Red Hour Films } \\
\text { Carlos Saldanha } \\
\text { Scott Free } \\
21 \text { Laps } \\
\text { Walden Media } \\
\text { Sunswept Entertainment }{ }^{2} \\
\text { Ad Hominem } \\
\text { Borderline Films } \\
\text { Decibel Films3 }\end{array}$ \\
\hline Paramount & $\begin{array}{c}\text { Bad Robot } \\
\text { Di Bonaventura } \\
\text { Ian Bryce Prods. } \\
\text { Disruption } \\
\text { Robert Evans Co. } \\
\text { Fake Empi re } \\
\text { Four By Two Films } \\
\end{array}$ & $\begin{array}{c}\text { Indian Paintbrush } \\
\text { Michael s-Goldwyn } \\
\text { Plan B } \\
\text { Platinum Dunes } \\
\text { Protozoa } \\
\text { Sikelia Prods. } \\
\text { Skydance } \\
\end{array}$ & Disney & $\begin{array}{c}\text { Boxing Cat Films } \\
\text { Jerry Bruckheimer Films } \\
\text { Mark Gordon Co. } \\
\text { Gunn Films } \\
\text { Mario Iscovich } \\
\text { Junction Entertainment } \\
\text { Lucamar Prods. } \\
\end{array}$ & $\begin{array}{c}\text { Mandeville Films } \\
\text { Mayhem Pictures } \\
\text { Gil Netter Prods. } \\
\text { Panay Films } \\
\text { POW! Entertainment } \\
\text { Secret Machine } \\
\text { Whitaker Entertainment }\end{array}$ \\
\hline Warner Bros. & $\begin{array}{c}\text { Alcon }^{4} \\
\text { Appian Way } \\
\text { Berlanti Prods. } \\
\text { Branded Films } \\
\text { Carousel Prods. } \\
\text { Cruel and Unusual } \\
\text { De Line Pictures } \\
\text { Di Novi } \\
\text { Executive Options } \\
\text { Gerber } \\
\text { Green Hat Films } \\
\text { Gulfstream } \\
\text { Heyday } \\
\text { KatzSmith } \\
\text { J.W. Prods. } \\
\text { Langley Park } \\
\text { Legendary }\end{array}$ & $\begin{array}{c}\text { Life's Too Short } \\
\text { Lin Pictures } \\
\text { Malpaso } \\
\text { Ninjas Runnin' Wild } \\
\text { Pearl Street } \\
\text { Polymorphic } \\
\text { Revelations } \\
\text { Guy Ritchie } \\
\text { RLFilms 2 } \\
\text { Roserock Films } \\
\text { Team Downey } \\
\text { 22nd \& Indiana } \\
\text { Village Roadshow } \\
\text { Weed Road } \\
\text { Wigram Prods. } \\
\text { Wychwood }\end{array}$ & $\begin{array}{l}\text { Universal/Focus } \\
\text { Features/Universal } \\
\text { Pictures Intl. }\end{array}$ & $\begin{array}{c}\text { Aggregate } \\
\text { Angle Films }{ }^{4} \\
\text { Apatow Prods. } \\
\text { Barnstorm } \\
\text { Bluegrass } \\
\text { Blumhouse Prods. } \\
\text { Captivate Entertainment } \\
\text { Cross Creek Pictures } \\
{ }^{4} \\
\text { de Passe Jones Entertainment } \\
\text { Global Produce } \\
\text { Gold Circle } \\
\text { Hurwitz \& Schl ossberg Prods. } \\
\text { Illumination Entertainment } \\
\text { ImageMovers } \\
\text { Imagine Entertainment } \\
\text { Jos ephson Entertainment } \\
\text { K/O Paper Products }\end{array}$ & $\begin{array}{c}\text { Laguna Ridge } \\
\text { Lava Bear } \\
\text { Mandalay } \\
\text { Media Rights Capital }^{4} \\
\text { Chris Morgan Prods. } \\
\text { Morgan Creek Prods. } \\
\text { One Race Films } \\
\text { Marc Platt Prods. } \\
\text { Silver Pictures Entertainment } \\
\text { The Tomante Co. } \\
{ }^{4} \\
\text { Wild West Picture Show Prods. } \\
\text { Working Title Films } \\
\text { Completion } \\
\text { Random House } \\
\text { Cattleya }{ }^{5}\end{array}$ \\
\hline
\end{tabular}

Figure from Bank et al. (September 13, 2013)

By moving away from mid-tier productions, the Majors have left open a market

that mini- and regional major studios attempt to fill. These are larger productions that either have a domestic or regional focus. Contrary to the historic interests in minimizing Hollywood dominance in domestic markets, many of the second-tier studios around the world have embraced their subordinate placement next to the Majors, seeing an opening for medium-budget productions. While Lionsgate is largely the sole remaining domestic mini-major, one can categorize dominant studios around the world in a new category of global mini-majors. These are regional major media companies such as Constantin Film( Germany), Vivendi (France), Village Roadshow (Australia). While these are large studios 
and leading distributors in their own markets, their films rarely move beyond the domestic market. ${ }^{32}$ Rather, large international releases tend to be in partnership with one of the Major studios. This helps assure international market access ${ }^{33}$ and advertising, as well as help any allocation of studio or investor partners, actors, or sourcing material. While this itself has increased the leverage of the Majors when operating in international markets, the central importance of maintaining a global oligopoly continues to be the MPAA and support from Washington.

\section{MPAA Cartel and the State}

I have demonstrated in the previous sections how Mass Media Conglomerates have dominated film production by increasingly consolidating their ownership and control of the most lucrative assets in the industry. Thus far I have emphasized the degree to which the Mass Media Conglomerates have used their market power to subordinate and limit competitors. These conglomerates have simultaneously expanded their political power and influence in the U.S. and globally. The incorporation of the Major Studios into Mass Media Conglomerates has exponentiated the political leverage and influence of the MPAA, which has broadened its focus from film issues to general media concerns,

32 "On average, EU films were released in cinemas in 2.6 countries whereas US films were theatrically released in 9.7 countries," with $63 \%$ of EU films being released in only one country, and $79 \%$ being only released in two or fewer (Grece, 2016, pp. 17). This is likewise true for Streaming Video On Demand (SVOD) services. While Netflix and other major streaming services are international, SVOD services in Europe are largely relegated to the domestic market, opposed to servicing the entire EU market or beyond.

33 Those that do seek international releases commonly need to rely on distribution services of the majors. This includes some larger indie studios that do have their own distribution services but are limited to domestic markets. The cost is usually around $18 \%$, with $8 \%$ being the actual cost of distribution, including advertisement services, with around $10 \%$ being profits for the majors. Some of the larger indie studios, especially with films that are likely to drive strong international revenue, can negotiate this as low as $10 \%$, with only $2 \%$ profit to the Majors' distribution company, but this is less common (Epstein, 2012, pp. 114). The decline of "mini-major" studios, which commonly offered a competitive distribution service, has actually made indies more reliant on the Majors for wider distribution. This growing reliance has additionally affected the financing of indie films (based on projected profits), and thus brought production and financing more into the hands of the Majors (Epstein, 2012, pp. 174). 
especially in regard to copyright law. As a result, while sector monopolization, blockbuster financialization, and development of production partners have various effects on film and media production and politics, the effects of corporate consolidation and industry collusion have a much more direct impact. This growth in structural power around MMCs and the corresponding instrumental power of the MPAA thus reinforce one another in its political influence.

Since its inception, the MPAA had a focus on developing strong relationships with political power brokers in Washington, D.C. The first president of the MPAA, Will Hays, is best known for Hollywood censorship and was nominally chosen for his moralistic reputation to clean up Hollywood scandals. ${ }^{34}$ But as the former Postmaster General as well as Chairman of the Republican National Committee, Hays had strong political relations in the nation's capital that helped develop the lobbying potential of the new association. Hays' replacement in 1945 was Eric Johnston, president of the US Chamber of Commerce, another lobbying group. Johnston, likewise, was politically connected, especially with Eisenhower (Valenti, 2008, pp. 271), but the political involvement of the MPAA increased dramatically under the presidency of Jack Valenti, who took over in 1966. While the MPAA was already politically engaged with Washington, it was Valenti who largely developed the role and focus of the MPAA that is still evident today. This was closer partnership with Washington in order to develop a

\footnotetext{
${ }^{34}$ The most noteworthy being the alleged rape and murder in 1921 of Virginia Rappe by famous actor Roscoe Arbuckle, known as Fatty Arbuckle. With other scandals occurring around the same time, many in the public began criticizing Hollywood as debaucherous and a danger of spreading this to popular culture. While a fanciful concern by today's standards, the corporate management of this morality continues to today. Interestingly, during the decline of the oligopoly from the 1950s-1970s ("New Hollywood" as defined by Biskind, 1999) the MPAA were more supportive of artistic experimentation, rather than moral conservatism. The conservatism, however, largely returned (though not to the degree of the Hays Code) as the oligopoly reshored its strength, with a mix of self-censorship and public support for moral concerns.
} 
stronger reach and access to international markets, which required far more leverage than dominating the domestic market.

The interest in expanding political connections to the executive can help explain the choice of Jack Valenti, due to his professional and personal connection as special assistant to Lyndon B. Johnson. This closer relationship between Hollywood and the White House continued into the Nixon presidency, assisted by the exponential growth for the cost of presidential campaigns and the need to find wealthy donors. Lyndon B. Johnson may have even wanted "one of his people" in Hollywood because of their possible donations for campaigns (Bruck, 2004, pp. 231). "Many of the corporations that made these illegal contributions were in industries dependent on government regulation-like the defense industry, the airlines, and oil companies. In the past, the motion picture industry would not have fit the pattern; but in the Nixon administration it did" (Bruck, 2004, pp. 315).

The political developments under Valenti were clearly a response to the decline of profit for the Majors, as well as preparation for more corporate-friendly policies from Washington. Thus, as opposed to keeping the government out of the industry, Valenti moved the MPAA close to the state. For the MPAA itself, this meant a move to increase political unity, capacity and organizational effectiveness, alongside the long-standing economic role of the association in increasing its members' market power. This allowed for a stronger political lobbying network, not just in the collective efforts of the MPAA, but also for the individual political actions of the Studios. While Valenti was a means for direct connection to LBJ, which continued under subsequent presidents, it was the presidency of Ronald Reagan that led to the major shift of the film industry and general economy. 
Reagan's presidency is commonly seen as ushering in the era of neoliberalism, by addressing structural changes in the economy via ideological and institutional changes. These resulted in the interlocking changes to many industries, which for film allowed the empowerment of the Majors through Mass Media Conglomerates. Compounding these systematic changes was the development of closer political relations by industry groups, such as the MPAA. Indeed, while this accelerated in the previous several administrations it was Reagan again that marked a particular advancement. Reagan was close to both the MPAA's Valenti and MCA's Law Wasserman, ${ }^{35}$ whom he knew when Reagan headed the Screen Actors Guild. The SAG was also Reagan's foray into the institutional and political side of the industry, as well as developing important personal connections. ${ }^{36}$ As president of the SAG, Reagan appeared to have a special relationship with Wasserman and the MCA, with special waivers and suspicious real estate deals, which even led to a congressional investigation (Bruck, 2004). Following his SAG tenure, Reagan joined MCA as a partner and received a lucrative deal as a host to General Electric Theater, further developing his industry relations.

With these interpersonal relations, it is then unsurprising that Reagan's ideology happened to favor empowering these institutions and individuals. This

\footnotetext{
${ }^{35}$ Lew Wasserman was a notable active president of MCA Inc. who had a strong role in reshaping the organization and operational structure of the film industry. Prior to incorporating the Universal Studios, the MCA under Wasserman was a talent agency that held a lot of power through exclusive actor talent. Utilizing this actor power, Wasserman developed many institutional connections with studios, producers, and broadcasters. With the purchase of Universal Studios by MCA Wasserman's activism expanded within the industry, developing an unofficial leadership position among the Major film studios. Wasserman was also instrumental in advancing political relations via personal connections and party fundraising, and was essential in accelerating the political activism of the MPAA and placement of Jack Valenti (Bruck, 2004).

${ }^{36}$ These connections potentially also include the Mafia, at least indirectly via Lew Wasserman's Chicago connections (Russo, 2007).
} 
coalesced around the neoliberal assumption that lack of regulation is the best way to facilitate free competition. Whether this was actually believed is hard to tell, but this policy orientation helped to entrench an oligopolistic structure within the U.S. economy that has expanded and persisted over time, allowing Mass Media Conglomerates to expand their ownership and control of a wide range of profitable industries and assets. Rather than contravene concentrated market shares, antitrust law was reshaped to allow mergers and acquisitions if these were thought to be compatible with "price competition," a lesser bar to overcome for corporations making their case for merging with or acquiring other firms. The previous standard used to prevent mergers and acquisitions was excessive market concentration. The new standard allowed greater market concentration as long as it was concluded that such market concentration would not adversely affect consumer prices. This shift not only weakened antitrust law, but combined with weaker antitrust enforcement, actively encouraged dominant firms to increase their market concentration and market power. Neoliberal ideology was utilized to justify these practices. Illustrative of this is the appointment of William Baxter, Reagan's assistant attorney general in charge of antitrust, who changed the vocabulary of antitrust to one of free market deregulation based on the Chicago school (Holt, 2011, pp. 11), and that of Mark Fowler who was put in charge of the FCC, also creating a neoliberal interpretation for the administration's role.

While the film industry has not reached the outright monopolization of Thomas Edison's Motion Picture Patent Company, the anti-trust deregulation, as well as the Mass Media Conglomerate structure, has produced an equivalent, if not more nefarious, effect in the economy and politics. The growing size and interrelation with other industries only further increases the reach and importance of corporate associations such as the MPAA. With still few members, shared interests, and growing economic 
reach, the cartel-like activity of the MPAA has grown. As MPAA president Jack Valenti put it, "...they were smart enough to know that they needed to work together in the best interests of their kingdom" (Valenti, 2008, pp. 285). The following chapter will follow this into the international sphere, where cartel-like activity had seen even less mitigation. This examination of international states and consumers forms the foundation of a dispersed coalition of mega power-brokers, led by the MPAA, that will be further examined in budget subsidization (chapter 4) and copyright extensions (Chapter 5).

\section{MPAA in International Markets and responses}

Despite antitrust limitations at home following the 1948 Paramount Decree the MPAA and Major Studios were tacitly allowed to continue cartel and anti-competitive behavior internationally that only expanded under neoliberalism. This chapter will start

with a short history of the internationalization of Hollywood as well as responses to it. Historically, nation-states outside of the U.S. used various means of economic protectionism in an attempt to prevent the domination of their domestic economies by the Majors. However, as economic liberalism became embedded in neoliberal institutions such as the WTO, strategies of economic protectionism became less viable. This led many nation-states to use cultural protections in an attempt to safeguard their domestic film industries from threats posed by foreign competition. The economic and cultural strategies used by nation-states to counter the Major Studios' internationalization 
were responses to an international oligarchy of corporate power that has grown considerably in the neoliberal period.

\section{Box Office Size by Region}

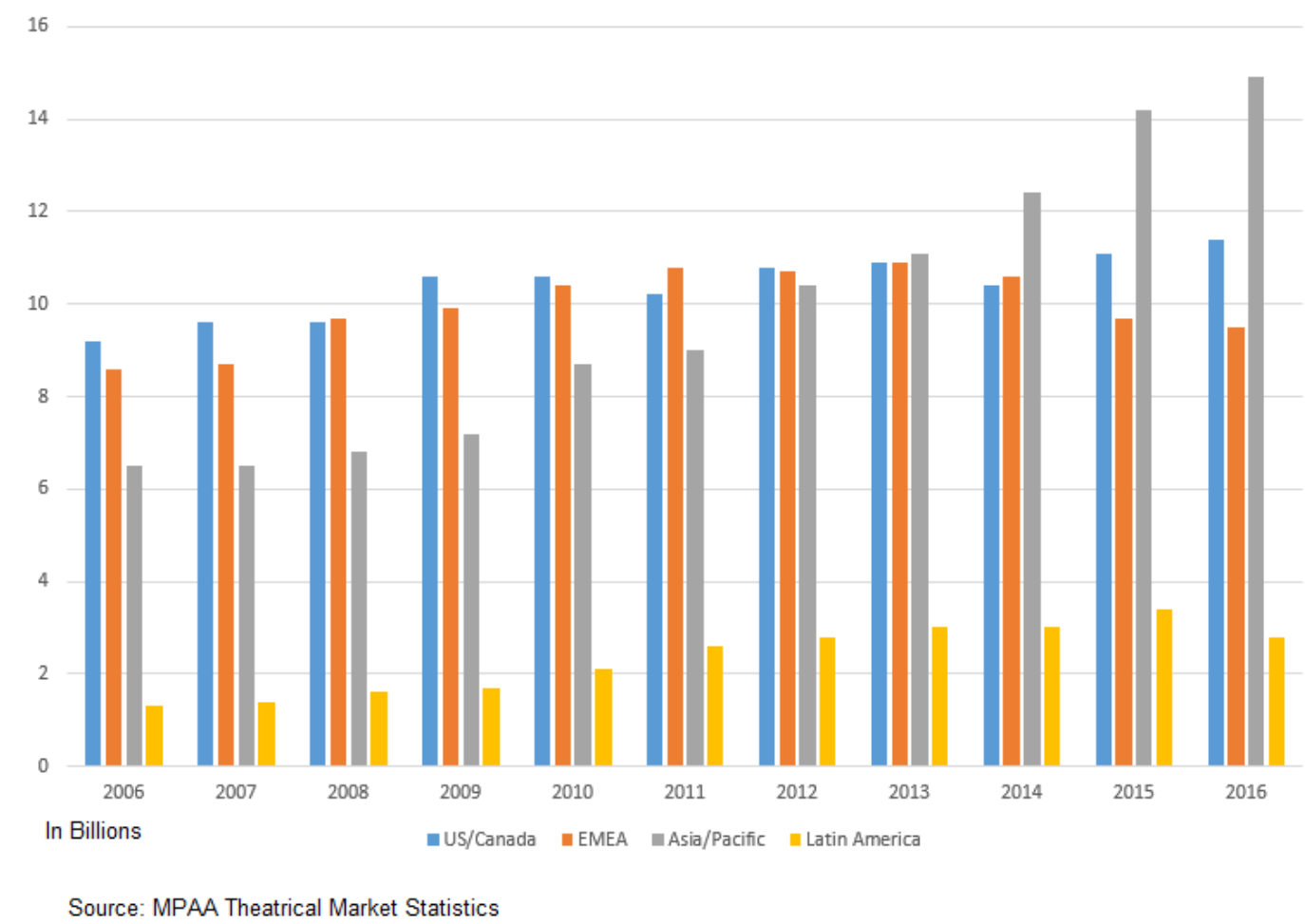

The Major Studios succeeded in countering the international backlash to their global expansion, which relied on support from Washington and the steady expansion of neoliberal policies. Today most regions focus on attracting production by the Majors, and in turn the Majors now receive more revenue from foreign markets than the domestic one (see Box Office Size by Region above). While the domestic market is still the single largest market for the Majors' revenue, all foreign markets combined provide more revenue today, and, more importantly, still have opportunity for growth. While some foreign markets are more dominated by the Majors, such as Latin America and others present future potential (primarily Asia), it was the European market that really shaped 
the MPAA and the Majors' international strategy. This is in part simply due to the connectivity of the economies, but also due to the relations between the European states and their respective film industries (See graphs below for Box Office share of Majors in leading markets). The European states' attempts to integrate with the U.S. market following WWII clashed with their economic vulnerability to dominant U.S. firms. The adaptive barriers and tariffs put in place to limit the Majors actually allowed the MPAA to learn to use international/systemic rules and norms, in tandem with state support, to generate benefits to specific corporations. This state-systemic strategy of the oligopoly will be incredibly important when examining the more complex modern iterations of these same issues in the following chapters.

\section{Major Studios share of Box Office, Latin America}

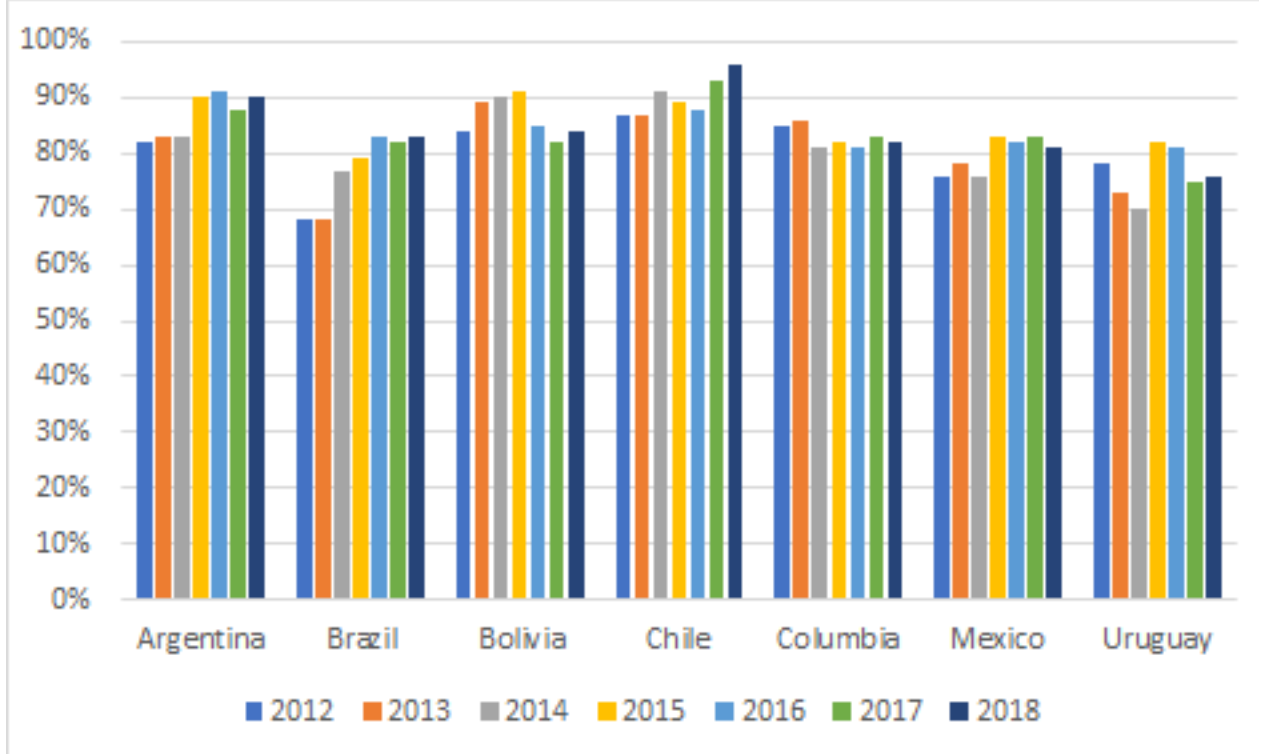


17.Major Studios share of Box Office, Asia

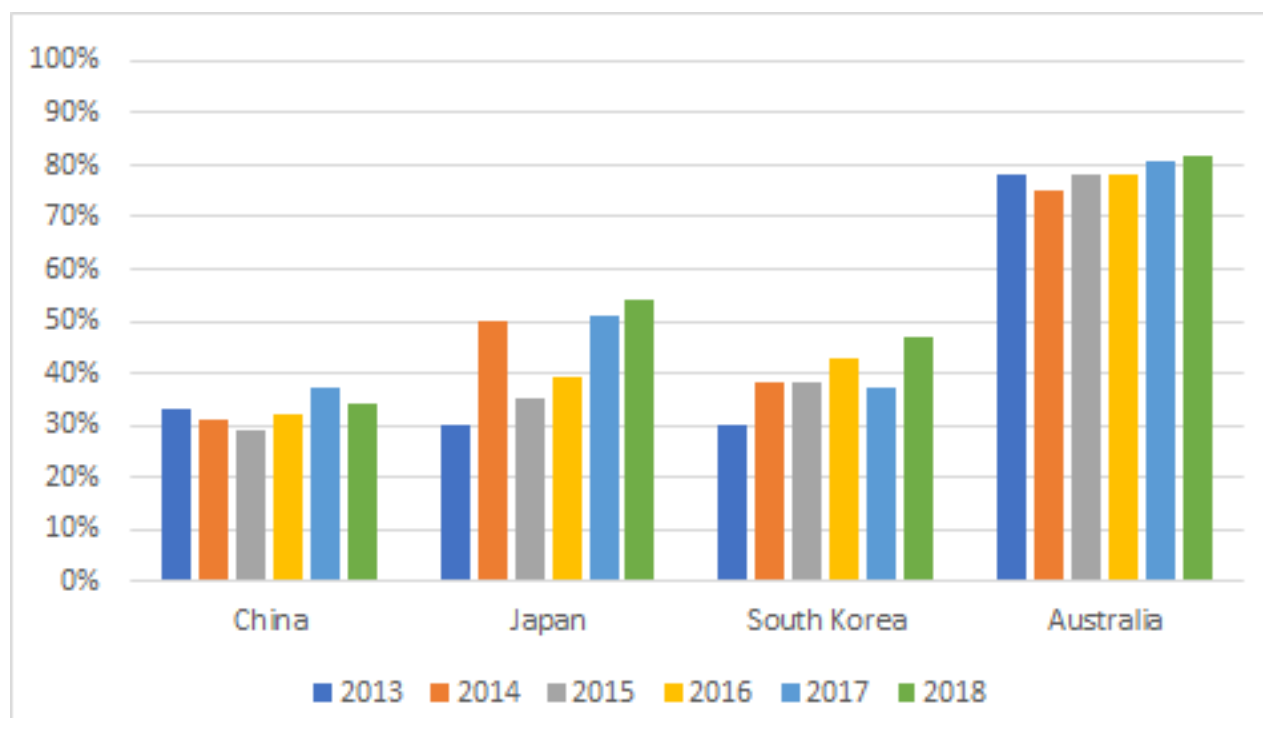

18. Major Studios share of Box Office, Europe

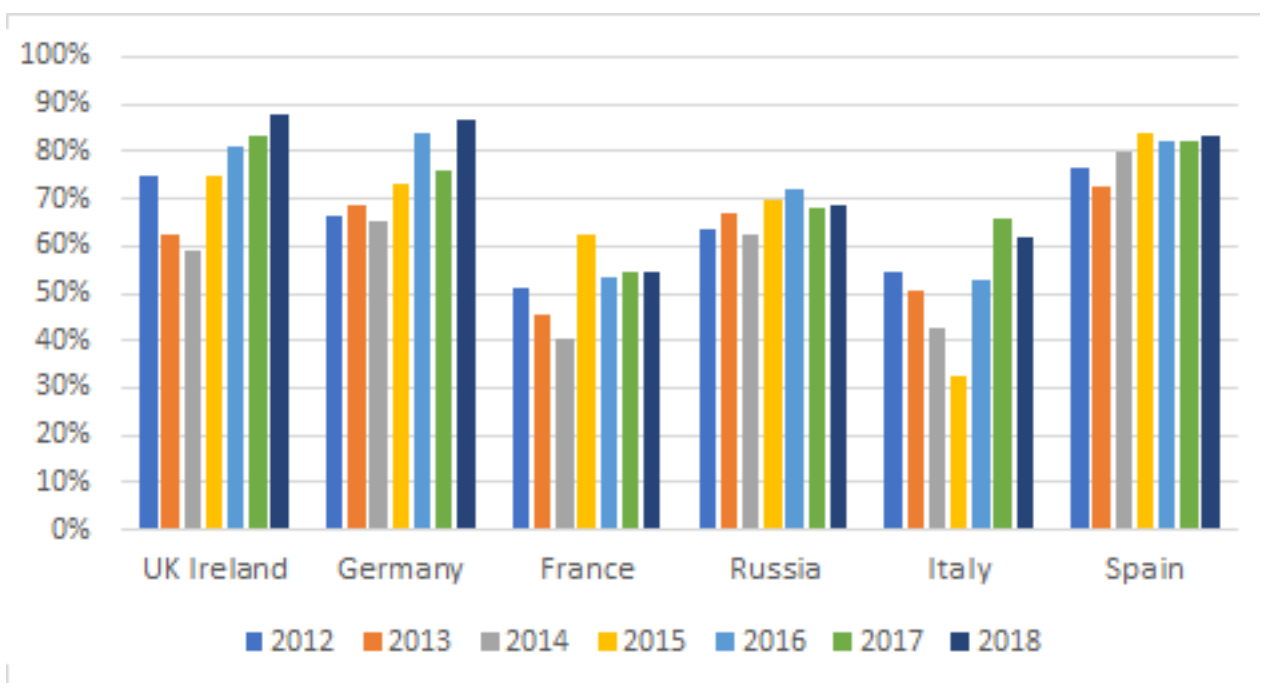

\section{History of International Film Monopolization}

At the dawn of the industry, the first film inventions and innovations were largely between the United States and France. While the US was a technological leader in many other industries, in this very early period it did not have the dominant position that we associate with the film industry today. Early on, European producers "...held a large share of the US market, which at times reached 60 per cent" (Bakker, 2003, pp. 187). It 
was actually the fear developed from these heavy film imports, both on economic and nationalist grounds, that helped lead to the first American film cartel under Thomas Edison, described in chapter one--an American film monopoly would fare better in the international market. This expediency also led to the reliance by the cartel on politics and law, such as film standards, patents, and protectionism, which helped reduce American imports of European film and pump up domestic production. While World War One is commonly seen as the shock to European producers that put American film on top, as the domestic industry grew around Edison's film trust, protectionism and tariffs were already being slowly loosened in America. Tariffs declined from $\$ 207$ per 1,000 feet of film in 1909 (shortly after the creation of the MPPC) to $\$ 97$ in 1913 (shortly before its end). By 1922 and the creation of what would become the MPAA, ${ }^{37}$ tariffs on film to the US were $\$ 57$, and protectionism was being replaced with internationalism by the new Film Oligopoly.

In combination with the destruction of WWI, there was a steep decline of European production, resulting in the trade relationship flipping as American film began to dominate the European Market early in the century. As Epstein (2006, pp. 86) reveals, "By 1926, American films accounted for nearly three quarters of the box office of Europe, and European ticket sales provided Hollywood with at least one third of its revenue." Foreign markets had become $30-50 \%$ of a studio's profits. Even following the Great Depression and a decline to around $20 \%$, this foreign revenue rebounded already by the late 1930s. By this time, Hollywood produced $75-80 \%$ of all film in the world (Balio, 1995 , pp. 32). Aware that this was not simply a result of war and market incumbency, European film companies did attempt to compete with what was already by then a

${ }^{37}$ Initially called the Motion Picture Producers and Distributors of America (MPPDA). 
transatlantic oligopoly. This was done by pushing for their own film consolidation with “...mergers, joint ventures, co-productions and distribution deals” (Bakker, 2003, pp. 253). However, this counter-association failed to produce any real counterbalance to the American studios. This is in part due to disruptions from the Second World War and in part due to the disjointed smaller markets of Europe ${ }^{38}$ not letting European Majors get off the ground. However, a primary factor was the early association and cohesion of the Studios in the U.S., along with both tacit and direct support from Washington.

\section{The Motion Picture Export Association}

While the Paramount Decree of 1948 and other antitrust regulation put strains on the domestic dominance by the Hollywood majors, World War Two resulted in another marked decline in European film production compared to the American market. This, along with the liberal trading system put in place after the war, allowed for greater market access and foreign revenue for the Majors. This occurred in markets which were "conveniently" out of reach of the Paramount Decree, which was limited to domestic operations. As foreign markets became increasingly essential, not only for revenue, but for the oligopolistic structure itself, the post-war environment marked a full transition for the MPAA in focusing on foreign market access and dismantling barriers to trade. For this, The Motion Picture Export Association (MPEA) was created in 1945 as the international arm of the MPAA. Much like Edison's MPPC, the MPEA functioned as a traditional cartel, but outside of US antitrust legislation. It acted as a single international distributor for all the Major Studios and MPAA members, allocating profits based on a

\footnotetext{
${ }^{38}$ It is only in recent decades with the European Union that there has been concentrated political power and finances to organize fully European Major Film Studios. However, as will be seen in this chapter and the next, this came far too late, as what mechanisms there are largely support the American Oligopoly.
} 
formula of box office receipts. Furthermore, it utilized block booking, the practice of requiring theaters to purchase blocks of films as opposed to individual films, which was another anticompetitive behavior curtailed by the Decree. For Washington, this development and acquiescence represent a consistent relationship with corporate collusion, which, banned domestically, was accepted and even supported in foreign markets to gain American dominance (Epstein, 2006, pp. 96).

As early as 1918 , the Major American studios were able to collude openly in foreign markets by utilizing the Webb-Pomerene Act, which explicitly allowed US corporations to ignore select antitrust regulation abroad. As such, not only could the early MPAA operate as a unified exporter for its members, it could also use that concentrated economic power as political leverage. As Bakker reveals (2003, pp. 254):

When in the late 1920s, France wanted to adopt strict and limited quotas for the number of films that could be imported, the Hollywood studios stopped supplying the French market for four months, after which the legislation was modified. The Hollywood studios were able to do this because together they held such a large market share that cinema owners and distributors could not do without American films. The latter groups lobbied heavily with their government to limit protectionist legislation. In similar fashion, the Hollywood studios withheld supply from the Italian market in the late 1930s, and from the British, French, Dutch, Danish and several other European markets in the years following the Second World War.

Especially following WWII, for many European distributors and theaters it was cheaper to import American films than try to compete with them as producers, allotting the MPAA this political leverage. For others, such as Germany and Japan, there was 
little choice but opening one's market to American films during post-war occupation (Lev, 2003). Much like the cartelization above, the support for opening markets to the oligopoly existed prior to WWII and the subsequent "American-led" free trade system of Bretton Woods. Already in the 1920s the U.S. Department of Commerce had set up a Motion Picture Division to support the industry in trade deals, providing political support rather than letting an international market operate. As Bakker argues (2003, pp. 245), this political assurance likely reduced any anxiety and, as a result, demand for protectionism from the American Studios in that period. While European protectionism would itself continue, it would continuously fail to counteract the entrenchment that Hollywood oligopoly had already achieved, along with support from Washington to direct that strength outwards.

In the post-war environment Hollywood market shares in both Europe and Latin America was generally large and dominant. However, it was the political relationship with Great Britain that was by far the most important. ${ }^{39}$ The British market alone brought profits from $\$ 70-80$ million per year, while all of Central and South America were only $\$ 15$ million (Schatz, 1999, pp. 156). Although this was an important foreign market for the Majors, no single market had the capacity to alter the leverage the MPPA had to enact its brand of unilateral and independent diplomacy on the state. Hollywood films were important to the success of British exhibition, so when, for example, an "ad valorem tax of 75 percent was placed on all future film imports" the MPEA implemented a boycott of the British market, successfully lifting the tax with another arrangement limiting profit repatriation (Schatz, 1999, pp. 299). However, due to both the shared English language and political difference between London and Washington, Britain was one of the first

${ }^{39}$ Again, besides Canada because it is considered part of the domestic market. 
markets to transition to actively supporting the oligopoly by integration and coproductions, rather than outright trade protection. This gave a foothold for the Majors to the general European market, but also helped develop the Majors' position as international co-producers and production managers, rather than simply film exporters.

19. Number of Theaters globally and share of American Films, 1949(Schatz, 1999, pp. 303)

\begin{tabular}{lrc}
\hline Region & Number of Theaters & \% U.S. Product \\
\hline Europe & $53,35^{\circ}$ & 56 \\
South America & 5,000 & 64 \\
Mexico/Central America & 1,950 & 75 \\
Far East & 3,500 & 47 \\
Middle East & 2,700 & 52 \\
South Pacific & 2,300 & 75 \\
Africa & 1,300 & 62 \\
Canada & 1,700 & 75 \\
United States & 18,350 & 95 \\
\hline
\end{tabular}

In the wake of the Decree and its effect on domestic market shares, by the late 1950s and early 1960s the increasing focus on foreign markets coincided and intermeshed with "...Hollywood majors transforming their business practices to one more of management in supervising productions, securing funds, arranging contracts, and marketing, as opposed to only producing feature films. This transformation toward becoming managerial entities marked the primary shift of the major studios away from being labor intensive-i.e., characterized by large staff on payrolls_-toward becoming capital intensive with fewer and fewer employees overseeing larger and larger investments" (Monaco, 2003, pp. 12). This flexibility on the part of the Majors facilitated the transition to neoliberalism, in part by incorporating international distribution into the 
oligopolistic competition. The MPEA was instrumental to this, by being a distribution cartel, handling distribution for all Hollywood Majors in countries rebuilding from the war (Schatz, 1999, pp. 302). As a result, the utilization of the oligopoly as a cartel to remove or subvert international barriers, had the effect of early neoliberalization in the industry, as they moved toward finance, flexibility, and political partnerships.

\section{Play-time of U.S. Films by Country (Silver, 2007, pp.4)}

\begin{tabular}{|c|c|c|c|}
\hline Nation & $\begin{array}{l}1930 \\
\text { U.S. share of playing } \\
\text { time }\end{array}$ & $\begin{array}{l}1960 \\
\text { U.S. share of } \\
\text { playing time }\end{array}$ & $\begin{array}{l}2002 \\
\text { U.S. market share based on admissions }\end{array}$ \\
\hline Japan & $22 \%$ & $21 \%$ & $\begin{array}{l}73 \% \text { non-Japanese share (mostly } \\
\text { U.S.) }\end{array}$ \\
\hline Britain & $75 \%$ & $67 \%$ & $82 \%$ \\
\hline Italy & $65 \%$ & $55 \%$ & $63 \%$ \\
\hline France & $48 \%$ & $33 \%$ & $56 \%$ \\
\hline Germany / West Germany & $32 \%$ & $29 \%$ & $\begin{array}{l}88 \% \text { non-German share (mostly } \\
\text { U.S.) }\end{array}$ \\
\hline $\begin{array}{l}\text { Average in other countries } \\
\text { (1930 average for } 16 \text { other } \\
\text { countries; } 1960 \text { average for } \\
\text { rest of the world) }\end{array}$ & $\begin{array}{l}75 \% \\
70 \% \text { in } 1933 \text { of } \\
\text { world playing time }\end{array}$ & $90 \%$ & $\begin{array}{l}73 \% \\
\text { (Europe in } 2000 \text { www.obs.coe.int ) }\end{array}$ \\
\hline
\end{tabular}

Sources: Segrave (1997) pp 284-285. Film Daily Yearbook 1934 p. 35; Film Daily Yearbook 1961 pp 97 ; Focus 2003 World Film Market Trends (www.obs.coe.int).

\section{Internationalization and Domestic Politics}

Although the MPEA would soon become known as "the Little State Department" (Schatz, 1999, pp. 289), and would engage unilaterally in foreign negotiations, this internationalism also helped contribute to Hollywood's partnership with American politics as well. As Schatz argues, “...ironically enough, that many of the same federal agencies that Hollywood was battling at home would look to the movie industry as an ally overseas." (Schatz, 1999, pp. 288). These included the Commerce Department assisting in developing a strong American position in foreign trade, the Justice Department relaxing its antitrust position specifically for expanding exports, and the State department. Hollywood became especially important for the latter as the Cold War brought more desire for the spread of American values. International dominance of 
Hollywood was a core propaganda tool, which brought state support and assistance for its transnationalization, as well as developing political relationships (Schatz, 1999).

Nonetheless, the most anti-competitive use of the MPEA--as unified distributor for the Majors--ended in 1957, as antitrust regulation was finally extended. But, the MPEA was not dissolved. Rather, it was restructured away from direct distribution activity to one focusing on politics, as the international branch of the MPAA. In 1994 it was renamed to the more benign sounding 'Motion Picture Association' (MPA). It is worth nothing here, that while the cartel function of the MPEA was eliminated, much of the international collusion, still banned domestically, continued for the Majors. Blind and block booking, ownership of foreign exhibition, and shared distribution were among these practices. Perhaps most notable was the creation of United International Pictures, an international distribution arm for Paramount and Universal, which was the largest international film distributor at its creation. UIP controlled up to $1 / 3$ of Hollywood's overseas market, and would come to "...dominate some European markets by as much as 85 percent" (Cook, 2000, pp. 305), as well as take on a distribution role for MiniMajors such as MGM and United Artists in 1981.

In tandem with involvement with Washington politics, the international role of the MPAA (and MPA/MPEA) expanded greatly with the appointment of Jack Valenti in 1966. At the beginning of Valenti's tenure foreign revenues for the Majors were at $\$ 1.5$ Billion; at the end in 2004 foreign revenues were $\$ 45$ Billion. This went from $24 \%$ of total revenues to $41 \%$ (Valenti, 2008, pp. 301). Like the MPEA, this brought an internationalization of the role of the MPAA, as its members become dependent on outside markets, of which it did not initially have the same political relationship as with Washington. To make up for that deficit the MPAA expanded its economic and political leverage on foreign governments, along with partnering with pressure from Washington, 
with which it had closer relations. The end-game of these relations would be to develop a coalition of actors, including governments, production partners, and politicians, to shape and open other markets in which the Majors have yet to access and dominate. Thus, international and domestic political power was just as essential as the product itself to develop a dependent international market. As a result, just as done with indie studios and producers during the Studio Era, international exhibitors and foreign studios looking for financial access would end up depending on Hollywood, giving economic and political leverage to the American firms.

It was under Valenti's tenure that the internationalization of the Majors and the MPAA reached beyond the traditional transatlantic markets. Although China was excluded, Asia was already being seen as the film market with most potential growth. As such, the "little state department" that was the MPA was expanding its reach as it deepened its leverage. When negotiating with India over repatriating Rupee profits out of the country, Valenti even undermined a parallel negotiation occurring from the Nixon administration so the Oligopoly could secure access (Valenti, 2008, Pg 286). Despite some such conflict, Washington was generally supportive of independent action by the group. Using the Special 301 mechanism, enforced by Washington (expanded upon below), Valenti was able to pursue negotiations with the president of Korea, in tandem with the US trade representative under the Reagan administration. The threat by the MPAA to pursue Special 301 punishment through Washington brought Korea to open up its film market, expanding Hollywood revenues from $\$ 9$ million to $\$ 177$ million in only six years (Valenti, 2008, pg 378). What is shown for this is that the MPAA and Major studios use unilateral diplomacy, partnership with Washington and other entities for greater pressure, and reliance on Washington to help establish a system to strengthen corporate unilateralism. 
This corporate power was facilitated by the post-war system designed to liberalize trade among allies, known as Bretton Woods. The manner of economic protectionism shifted from simply external barriers, such as tariffs, to more complex protections. Many European states that signed agreements during the Bretton Woods period (1945-1973) to reduce tariffs began limiting the repatriation of profits by foreign companies, such as the Major studios. This form of protectionism was less contradictory to the liberal order, and was intended to assure that profits gained by the early multinational corporations would not result in flight of capital. It was also to encourage local productions and jobs even if the industry became heavily dominated by the American Studios, by compelling the Studios to finance productions where their capital was stuck anyway. Trapped revenue expanded international production by the Majors that blurred nationality, which was especially true as coproductions were increasingly common with local studios, especially in the UK. Contrary to limiting the power of the Studios and the MPAA, this increased their leverage as more entities became dependent on relations with the Oligopoly.

This internationalization of production will have further implications as national film subsidies come into play, as the Majors' internationalized productions could qualify as "European" in many cases. In the meantime, the leverage this afforded to the Oligopoly extended their industry diplomacy. States that did put taxes on foreign films, such as the (UK) or that limited profit repatriation too much (France) found themselves faced with further boycotts by the MPEA. The withholding of American films could already harm numerous actors dependent on their importation, such as theaters, smaller studios, and even consumers who desired the "hip" American film. Increasingly the Majors could also threaten to withhold investment as well, harming local producers, studios, and labor. This success and growth of actors with ties and dependent on the 
Majors, set the ground for an internationally political Motion Picture Association (MPA), as successor to MPEA, as well as being an independent negotiator with foreign governments.

\section{The Film Oligopoly under Neoliberalism}

Once again, it is the transition into the neoliberal period that marks the modern structure of the industry, in which we see the same collusive strategy, but with adapted tactics. The cartel-like activity and political involvement of the MPAA continues, but with an increasingly larger industry at its back, as described in the previous chapter.

Commensurate consolidation and monopolization in other industries also means easier inter-industry partnership to influence the system and governments. New institutions, such as the World Trade Organization and Free Trade Agreements, likewise mean more avenues for such associations to operate. All in all, the neoliberal system gave not only a structural benefit to the large and monopolized multinational corporations, but extended their institutional influence as well. In contrast, the free market hegemony of neoliberalism pushed states worried about Hollywood domination from an economic and profit repatriation concern, to one of cultural protection. Over time this too was overcome by neoliberalism as most states now focus on how to integrate local film production with the Major Studios, rather than attempt to limit them at all. The eventual failure of such concerns and protections betrays the fact that both economic and cultural issues need to be factored into the political construct of power, of which the Majors, as leading media purveyors, have been increasing for many decades.

National strategies of economic and cultural protectionism have failed against an increasingly concentrated corporate oligopoly supported and empowered by international economic institutions. As I discussed in chapter 2, the Majors expanded 
their ownership of the highest valued assets in the global firm industry, which allowed them to increase their leverage against potential rivals. This included the growing focus on blockbusters and franchises that were directly tied to the inclusion of financial liberalization and Intellectual Property protection into international rules and norms. The largest shift can be seen in the replacement of the General Agreement on Tariffs and Trade (GATT) with the World Trade Organization (WTO)-- a process that overlapped significantly with the restructuring of the Major Studios into Mass Media Conglomerates (1986-1994). The culmination with the WTO marked a clear shift from a focus on decreasing tariffs and external barriers, to incorporating domestic laws, such as corporate protection, financial liberalization, and, perhaps most importantly for the Major Studios, the creation of Trade Related Intellectual Property Rights, or TRIPS. TRIPS set a minimum protection of Intellectual Property for WTO members, 50 years for copyright and 20 for patent, as well as delineating what is to be protected and how. For the oligopoly, this also set a strong norm for market openness and copyright protection, which could then be extended outside of the WTO (such as in trade agreements or bilateral trade deals, with even stricter requirements than TRIPS).

In the case of the WTO, corporate interests fused with the agendas of the governments of developed countries in the global North, who sought to advance the interests of their most technologically advanced and globally dominant industries. Into the 1980s, the US was facing domestic criticism of what was becoming a perpetual trade deficit. To turn this around without reducing trade, Intellectual Property was shaped into a trade issue, largely by the lobbying of corporate interests. Because developed states had an advantage in privileging market protection for Intellectual Property Rights, the U.S., the E.U. and Japan pushed for these protections within the WTO and within regional and bilateral trade and investment agreements (Cox, 2019). This shift in 
privileging Intellectual Property Rights was driven by dominant multinational corporations, whose profit margins were increasingly tied to a greater dependency on ownership of Intellectual Property Rights. These corporations worked with their home governments to expand global protection of IPR through the Uruguay Round of GATT and through the WTO. As Sell argues the new WTO rules, including TRIPS, were unique to the previous GATT agreement, in that they applied "to the rights of private individuals rather than to goods" (Sell, 2003, pp.13). Corporations and corporate lobbying networks and associations lobbied for TRIPS and other forms of expanded market protection, which included the MPAA on behalf its oligopolistic members. The major trade association formed for this purpose was the Intellectual Property Committee (IPC), made up of competing corporations from IP industries such as pharmaceuticals, media, and computer technology (Sell, 2003, pp.96). This was assisted by other associations such as the International Intellectual Property Alliance (IIPA), itself comprised of seven trade associations in copyright industries, including the MPAA.

By providing a trade-based solution to the decline of competitiveness and increasing deficits, this large group of corporations and executives were able to align their own interests with the interests of powerful states such as the U.S., the E.U. and Japan, with the U.S. government being especially aggressive in pursuing the interests of its film oligopoly in expanding protection of IPR in foreign markets that were most important for profitability. This corporate-state effort to redefine and emphasize the importance of IPR in global and regional trade agreements helps further shift the concept of Intellectual Property itself to an inherent right in capitalism and a requirement for innovation or even the welfare of developed states (May, 2000). This is opposed to previous conceptions of IP as contributing to monopoly control of products, which has a negative effect on free trade, and facilitates corporate protectionism after an innovation 
is already created (Boldrin \& Levine, 2008). Instead, the TRIPS agreement extended the scope, length, and coverage of IP laws internationally. In the end, the TRIPS provisions within the WTO were an exceptional win for developed countries and the multinational corporations involved. For the Major Studios, this was largely a means to an end, rather than an end-in-itself. The rules and norms in place would be used as a baseline to be extended in other bargaining tactics by developed countries, as well as within regional trade and investment agreements (chapter 5). These investment protections of intellectual property would then set a new norm that would be used against states whose markets were "lagging behind" in promoting corporate friendly practices. There is no better illustration of this practice than the unilateral power afforded the MPAA and others, through the US Special 301 trade mechanism

\section{Special 301 - Expanding State Partnership}

With the interest of IP and copyright ostensibly tied to the well-being of the American economy, the US had chosen to not only rely on WTO enforcement on TRIP rules, but to utilize unilateral pressure, influence, and even the threat of sanctions in the form of "Special 301" Report. "The "Special 301" Report is an annual review of the state of Intellectual Property Rights protection and enforcement in trading partners around world..." ("2012 Special 301 Report”). As claimed by the report itself, this "reflects the Administration's resolve to encourage and maintain adequate and effective IPR protection and enforcement worldwide" (2012 Special 301 Report). In practice, Special 301 has been used as direct and indirect pressure for states to enforce Intellectual Property norms as defined by Washington rather than the WTO. Due to corporate input in determining offending states, this amendment of the Trade Act institutionalized the input and influence of the private sector in U.S. trade relations, and has been described 
by the MPAA as an effective tool in dealing with trade barriers and piracy (Lee, 2008; Shiu 2006).

In the Special 301 report the Office of the U.S. Trade Representative has the option to place countries in one of three lists after investigations which include private petitions. The highest category is "Priority Foreign Country," which is reserved for countries that have "the most onerous and egregious acts, policies, and practices which have the greatest adverse impact (actual or potential) on the relevant U.S. products" and have not engaged in negotiations with the U.S. or made significant progress (2005 Special 301 Report). The second category is "Priority Watch List" which is for countries whose lack of enforcement is a major concern to the U.S. and copyright holders. The least severe category is "Watch List," which is designated for countries not as bad as Priority Watch List, but that pose a concern and are "subject to increased bilateral attention" (Shiu, 2006). Countries that do not alter their IP laws or enforcement, or actively work at correcting them within a specified time frame will be moved up the list and eventually be faced with tariffs, quotas, other trade sanctions (Shiu, 2006, pp.622).

Corporations most dependent on ownership of IPR invariably take the lead in lobbying for Special 301 reports. This means that PhRMA, a trade association for leading pharmaceutical corporations, and the International Intellectual Property Alliance (IIPA), focused on Copyright, have emerged as important players in this lobbying network. The IIPA itself is an interesting brand of trade association that largely functions as a "peak association" (Brady, 1943), which is a federation of trade associations and includes the MPAA as one of its members (See List). The overlapping operations of such lobbying groups has a large impact on the bounding power of corporate influence, especially for the more active and cohesive associations within the IIPA, such as the MPAA. For Intellectual Property, the overlapping interests has resulted in an 
"increasingly powerful lobby" group comprised of the IIPA, the Pharmaceutical Manufacturers Association, the Chemical Association, National Agricultural Chemicals Association, and other IPR industries and associations (Sell, 2003, pp.76). As the Special 301 Report has been "remarkably responsive" to MPAA and other private actor's suggestions, the MPAA and other like-minded industries have continued to expand their influence on the government on trade issues (Lee, 2008).

\section{International Intellectual Property Alliance members:}

- Association of American Publishers (AAP)

- Business Software Alliance (BSA)

- Entertainment Software Association (ESA)

- Independent Film \& Television Alliance (IFTA)

- Motion Picture Association of America (MPAA)

- National Music Publishers' Association (NMPA)

- Recording Industry Association of America (RIAA)

While many states end up on Special 301 due to weak capacity to enforce IP laws,$^{40}$ the MPAA focuses on states that are soft on digital piracy in order to protect online privacy or to avoid censoring websites. As such, Washington has worked closely with the MPAA and related associations to add states to the Watch List when these states are deemed to have under-policed violations of copyright laws in favor of other domestic priorities. Notably, many European Union members have faced such pressures from Washington. Among them, Spain and Italy have been consistently placed on the Watch List in the past over online copyright protection. Infamous among Digital Rights

\footnotetext{
${ }^{40}$ Developing states tend to run afoul on counterfeiting, while more developed states run afoul on online piracy and pharmaceuticals, commonly over balancing digital privacy and medical costs, respectively.
} 
groups, Spain notably enacted the "Sinde Law" in 2011, which expanded powers to force websites to take down infringing material, along with website blocking and shutdowns (Sutton, 2012). It has since been revealed that this law was a direct result of US pressure through Special 301 (Enigmax, 2012). Spain was specifically placed on the Watch List due to lack of criminal penalties for online file sharing (USTR, 2010) and in 2011 the USTR was being lobbied by the IIPA to escalate Spain to Priority Watch List, the year the law was enacted. By capitulating and reshaping laws to Washington and IIPA demands, countries like Spain participate in shaping international norms. Future actions by the IIPA and like entities, can utilize the interaction and outcome to pressure other states to follow this norm. ${ }^{41}$

This expansion of IP and pro-corporate norms can likewise be seen in the growth of multilateral, regional and bilateral trade and investment agreements, which have increased exponentially under neoliberalism. During the period from 1990-2010, there have been as many as 400 trade agreements and over 3000 bilateral investment agreements negotiated by states. Most of these agreements have privileged strong enforcement of investment provisions favored by powerful states and corporate interests. Countries of larger size and market power have been able to extract concessions from developing countries on IP protections, with multinational corporations often playing a prominent role in the negotiations.

\footnotetext{
${ }^{41}$ As will be seen in chapter 5 , these norms developed internationally are also used as a foundation to reshape American policies and laws, such as American freedom of speech laws that have been especially stubborn for copyright groups looking for censorship and website blocking.

${ }^{42}$ Perhaps most notable was the access to negotiation progress for Trade Agreements, which has since become infamous and for many a sign of not only undue corporate power in government, but a direct displacement of democratic input and transparency. Reportedly the strenuous requirements for congressmen to access recent trade negotiation progress and
} 
The infamous Trans Pacific Partnership, 42for example, had taken much of its content from the United States-Korea Free Trade Agreement (Fergusson, McMinimy, and Williams, 2015). Included in this was the minimum copyright protection for 70 years, far above the minimums set by the TRIPS in the WTO. Despite the U.S. leaving the agreement, the copyright minimum remained among the existing members. This brings the 70 year minimum, which was already the EU requirement, into many growing economies in Eastern Asia, setting a legal norm that can then both be expanded regionally, as well as push this minimum in the future closer to the U.S. copyright limit of 95-120 years (based on publication or authorship).

In regional, bilateral and multilateral trade agreements that include the U.S., the U.S. Special Trade Representative works closely with corporations in negotiating the details of these agreements. Corporate interests have been institutionalized in the bargaining process with the creation of Industry Trade Advisory Committees in 1974. These operate as a mixed public-private "peak association" that blurs the line of corporate and national interests, as well as personal relations that help drive the revolving door of corporate and state bureaucratic careers. Today ITACs are divided into 14 industrial topic areas, each of which is composed of representatives from leading corporations or interest groups, such as trade associations. ${ }_{43}$ For example, the Intellectual Property Rights ITAC currently has representatives from The Disney

proposals, such as TPP and TTIP, was within a secluded and guarded room with no means to record information [save a sheet of paper]. Members of the European Parliament faced the same limitation with TTIP. However, CEOs of leading corporations, who were partner to the negotiation, received a login and password, and could access the negotiation process from anywhere--a far cry from what the political representatives faced. While these occurrences produced outcry from those concerned with transparency and corruption, the concerns unfortunately failed to produce a broader examination to the genesis of such corporate institutionalization in the state.

${ }^{43}$ Broken up into district committees, representatives from Disney, the Entertainment Software Association, and the International Intellectual Property Alliance, are members to ITAC 13 on Intellectual Property Rights. 
Company and the IIPA as members. ${ }^{44}$ Thus, when relevant IPR issues are under negotiation there can be direct and clear input, or "advisement" to negotiators. While this has a clear benefit, the problems are just as clear. Catering to the most powerful actors in any particular industry will account for the largest impact the trade deal will have, which typically excludes input from consumer or environmental groups (Simmons), while also crowding out smaller competitors in the industry unless they are members of a larger association that has representation. On the other hand, for large multinationals, such as the Mass Media Conglomerates, institutions such as the ITACs provide numerous and growing influence and power in the process. The Major Studios, who already have the IIPA ${ }^{45}$ and Disney on the Committee, also have shared interests with most others. Pharmaceuticals ${ }^{46}$ and computer technology generally have a large number of seats, and AT\&T, the new owner of Warner Bros., is a member of the Digital Economy ITAC.

\section{Integration into the Global Film Structure}

As neoliberalism normalized rules of the system and supported unilateral corporate power, the balance between integrating into Hollywood's global system and limiting their access to domestic markets swung heavily toward the former for many countries. Especially later into the 1990s and 2000s, this replaced much residual protectionism for domestic film with actively attempting to attract the production from the

\footnotetext{
${ }^{44}$ Membership to ITACs change over time. Other Majors Studios have been members as has the MPAA itself.

${ }^{45}$ Entertainment Software Association is also a member, along with IIPA. That this association is also a member of the IIPA as well reveals the large amount of overlap.

${ }^{46}$ Pfizer is currently one of the members of the Intellectual Property Rights ITAC, with Disney and the IIPA.
} 
Major Studios, which increasingly shot in multiple locations around the world. What limited protectionism was left for Western markets was largely around concerns for culture and language. This was especially true for Canada, which required cultural exceptions for negotiating NAFTA. For Washington and the MPAA, limiting market access for Hollywood over cultural concerns were viewed as nothing more than hidden protectionism.

In practice, however, cultural protections were much more limited than historical trade barriers for film, and by the new millennium cultural media protection was a stronger complement to neoliberalism than a contradiction. This is due to the fact that support for film production shifted from protecting against film imports to integration with transnational film production. For many European subsidy programs, culture and language is indeed an important consideration when choosing films to support. However, as neoliberalism and integration into the global film market took the fore, integration with the Major Hollywood Studios' production and distribution streams have become the primary concern. In this sense, most economic subsidies became active support for the major studios, with only residual protection and a fraction of subsidy funds for culturally significant or artistically important works. Major economic film production would largely be done alongside and in partnership with the global oligopoly.

This modern shift from supporting domestic film to integrating into Hollywood oligopoly has much to do with how Western European countries adopted neoliberal policy, compared with the U.S. Where American deregulation in neoliberalism was focused on reducing antitrust regulation, Europe was privatizing and breaking up stateowned media that had been, in part, used to limit foreign media dominance (Hernan Galperin). Thus, not only were external economic barriers being reduced, but the internal legal change from neoliberalism was being applied in different ways. In this environment, 
many European states removed two layers of economic safeguards in their adoption to neoliberalism: external barriers and state-run and supported media. It is thus in this environment that dominance of the American oligopoly was accepted, and European states looked to attract blockbuster production and fill in regional and mid-tier film gaps left over.

A major issue for the EU is that continent-wide deregulation did not form a comparable-sized European media structure. As a result, a scattered and divided market existed alongside the privatization and lowering of external barriers. The assumption that a "European Culture" would form in place of economic interventionism proved naive, and transnational European film centered around French and English film markets (Galperin, 1999, pp.635). The latter of which, as the British market, was again, the most open to Hollywood integration and ultimately used as a stepping stone to the European market. This heavily defaulted the largest European contention to American cultural dominance to France, which continues to export the highest number of European films to other continents alongside British (English speaking) films, but still far lower than the Hollywood competitors.

This largely leaves a double-role for European production, which is similar to the function of Mini-Major studios. While American Mini-Majors have largely disappeared, with the exception of Lionsgate, the role of independent, mid-tier production and partnering with Major studios for funds, production, and distribution, has largely moved to the global level. Thus, many major European producers, along with supportive governments and subsidies, operate as Mini-Majors of the new global film system. Locally these studios fill in domestic, or at most regional, production for particular languages. However, these do not go much farther than shared languages, such as French films in Belgium, or German films in Austria. As such, even inside the EU as a 
whole, it is beneficial to partner with American studios for widest release: Between 2005 and 2014 64\% of films released in EU cinemas were produced in an EU member country, but these only accounted for $27 \%$ of EU cinema admissions (See chart). It was U.S. films that took $70 \%$ of cinema tickets in the EU, despite being $16 \%$ of total film releases.

21. Theatrical Releases versus Film Admissions in EU, 2005-2013 (Grece, 2016)
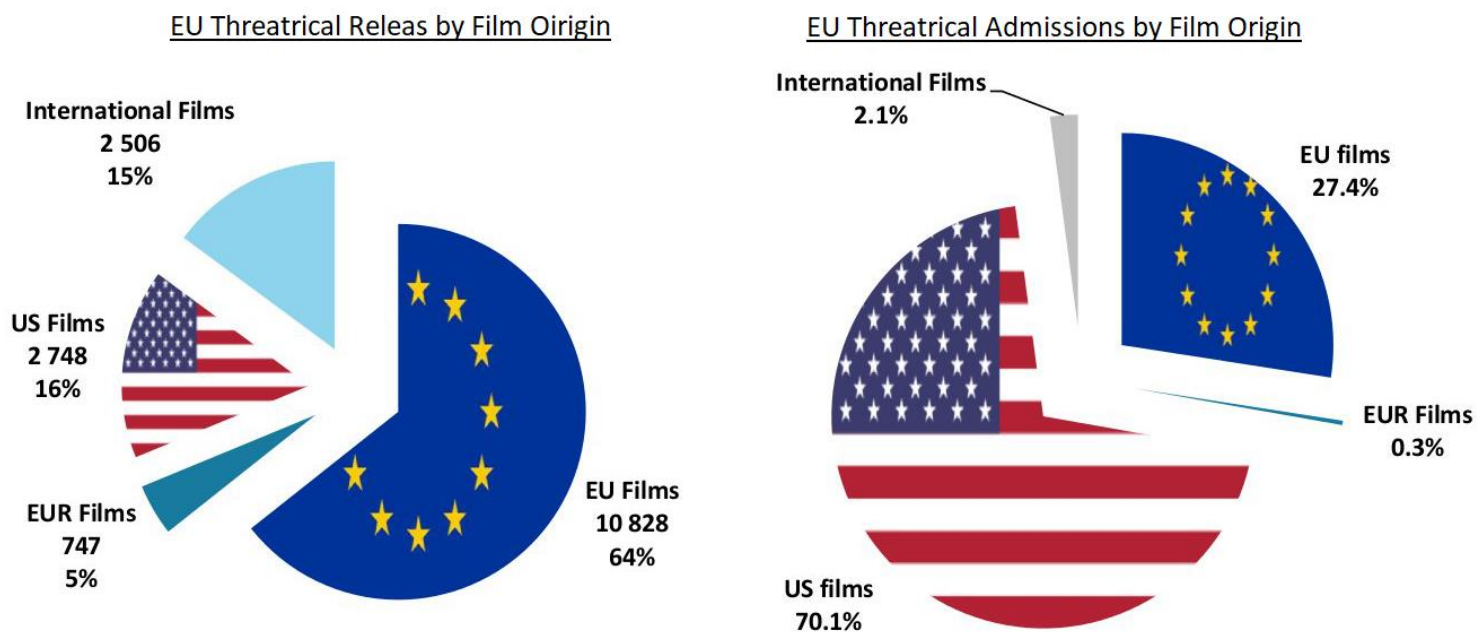

Outside of Europe, these releases are even more limited. EU productions only had 97 million admissions in non-EU markets in 2017 , with the majority coming from the quickly growing market of China and Hollywood's domestic market in North America (Kanzler and Simone, 2019). While large in absolute numbers, this is comparable to film admissions of only the German market of 94 million ticket sales in 2016 (Blaney, 2017), and much smaller than Major Studio releases in North America at 1.32 billion (MPAA, 2016), which, again, make up about half of Major Studio revenue. Still dwarfed by Hollywood releases in all markets, EU films have seen their highest foreign market sales increase in China, likely impacted by the China-US trade war. China has become the largest foreign market for EU films by ticket sales, but are still behind even North 
America in terms of revenue (Roxborough, 2019), limited along with American films behind the Chinese quota system.

\section{Conclusion}

These moderate goals of second-tier film distribution, not only globally but in European markets as well, reveals the very clear development of a global system of film studios revolving around the Majors, as well as the accepted relegation of most major foreign competitors to a new international Mini-Major status. The initial protectionism from European markets were not enough to contend with a growing and increasingly global Hollywood, especially as Europe repaired itself from the shock of the world wars. By the time most industries recovered in Europe, American film imports were very much the norm and expected by consumers. This development, combined with the eventual pressures for neoliberal deregulation and free markets, made the choice between competition or integration with globalized Hollywood a clear choice for the latter by regional studios.

Very importantly, this period of neoliberalism also marked a strong increase of unilateralism from transnational corporations like the Major Studios and their association, the MPAA. The economic influence and collusion allotted to corporations, which even during the New Deal period of strong anti-trust was growing, has only expanded under neoliberalism. The Mass Media Conglomerates of the MPAA have become larger, but have also continued to add political support to their foreign activities. Naturally this was stronger from Washington, including via mechanisms like Special 301 or consultations in ITACs, but support has increasingly come from other world governments as integration and attracting Blockbuster production from the Majors became a major political goal. 


\section{Corporations, Associations and the State: The International Subsidy System}

Today there is the normalization and expectation that film production undertaken by multinational media corporations based in Hollywood (and hereafter referred to as the Majors or Studios) will be subsidized by some level of government--local, national, or foreign. Subsidization of production costs--literally paying for a portion of the filming costs--is so pervasive today that most studios, and especially the multinational Majors that dominate the global industry, require it when choosing a location. Even the countries that have a history of film and cultural protectionism have adopted this strategy to attract Blockbuster productions for the sake of jobs and investment from the Majors. While this follows standard trends in market concentration in many industries, film production is especially notable due to its flexibility in production. That film productions are temporary, commonly shot on location, and consequently mobile, means production Studios do not need to permanently maintain crew, studios, and equipment in all locations they shoot. As a result, Studios have maximized their flexibility in shooting on varied and diverse locations, both within the U.S. and abroad. This results in Studios maximizing choices regarding where to shoot films. Thanks to this and their political, market, and financial power, the film industry has long established a pervasive and international system of countries 
competing for film investment through subsidies. I will refer to this as The International Subsidization System.

Film subsidization has a long history, but since the 2000s this International Subsidization System reformed itself as a core component of Hollywood production. Under the common neoliberal defense to gain "jobs and competitiveness," numerous provinces, states, and countries have joined in subsidizing film production in order to attract this very mobile industry. For film and other industries this has generated a "race to the bottom" where competition no longer exists simply on natural qualities (such as the most appropriate shooting location for film or studio infrastructure), or even regulation competition (such as wage and safety provisions), but has swung in favor of supply side factors so that the choice of production location is heavily determined by direct cash transfers provided to the requisite film or media corporation. Naturally this has resulted in an advanced form of race to the bottom, where, in combination with downward pressure for wages, unionization, and regulation, states are participating in financing production with no direct return on investment. The Majors claim that subsidization will bring employment, local production spending, and production infrastructure that is often advertised as contributing to a selfsustaining local industry. However, as will be seen, with the number of governments participating in film subsidization, the returns on government investment have mostly proved elusive.

There has been much debate over the efficacy of corporate subsidization before the particularities of film subsidization are considered. Thom (2016, pp. 1) 
shows that "...some evaluations find positive (Wu, 2008; Zhang, 2015) or mixed effects (Langer, 2001; Wilder \& Rubin, 1996), others provide no evidence of positive long-term impacts (Peters \& Fisher, 2004; Prillaman \& Meier, 2014; Taylor, 2012)." Others argue that subsidization has little effect on location choice for production (Lynch, 1996) and is thus simply paying for production that already exists. At best, positive outcomes from incentives and subsidies tend to be fleeting, either as the market catches up to the adjustment (Thom, 2016), or as competing programs crowd out initial gains of early adopters (Thom and An, 2017). The mobility and temporality of these projects, as well as the expanse of the subsidization scheme, means film subsidization should be one of the least useful industries to subsidize. Despite this, or perhaps because of this fact, the leading industry lobby, the Motion Picture Association of America (MPAA), has actively supported the cultivation of this system due to the direct benefits such subsidization provides to their corporate members. As such, in 2011 film subsidies took up nearly $2 \%$ of total subsidies within the US. While seemingly small, when compared to the largest subsidized industry of auto manufacturing at $\$ 5$ billion, in 2012 the cost per employee was $\$ 12,465$ for Film Production while "only" $\$ 6,745$ for Auto Manufacturing. ${ }^{47}$

${ }^{47}$ See Story, Fehr, and Watkins (2016) for subsidy amounts and U.S. Bureau of Labor Statistics and U.S. Census Bureau (2015) for employment numbers. 


\section{Runaway production}

This direct subsidization of industries is uniquely high in film due to the mobility of production. While film production may conjure up images of artificial sets and warehouses, location shooting has long been central to the industry and was a major reason for choosing Hollywood as a primary location due to the varied ecology of California. Because the end product could easily be distributed across the country, there was little necessity to stay in New York, the original film capital. In fact, to be a film production company and distributor, ownership of a physical studio is not always necessary, such as United Artists, which was a production house "Studio" with no actual studio. Rather than directly own a studio backlot, the company would produce films and rent studios as needed. Without this overhead, producers are easily able to choose between locations and studios based on their needs. This particularly flexible and mobile aspect of film production led to its own industry term of "runaway production." While good from a studio's point of view, the derogatory nature of "runaway" was developed from the perspective of critics who saw production, investment, and jobs unjustly leaving Los Angeles. More generally, this attests to the inherent flightiness of such temporary and mobile projects, which grew under neoliberal capitalism as flexible production became normalized.

This project-based and temporary nature of film has a large impact on transforming run-away production into an industry-wide norm (Thom and An, 2017), but the nature of film production also plays a major role. Because of clear segmentation of production, one film can easily be done in multiple locations. 
This includes not only the actual filming, but also with pre- and post-production, which has even fewer locational requirements. With computer graphics and the use of green screens, many of the artists and film workers do not even need to be in the same location. This manner of production has itself helped solidify the labor delineation within the film industry, between "above-the-line" and "belowthe-line" labor. The former includes the higher paid jobs, such as producer, writer, director and actors, while the latter refers to more physical jobs such as technicians, grips, set artists, and stagehands.

In relation to the supply chain hierarchy, these labor categories can be considered "higher value-added" and "lower value-added," but also relates the mobility of production. Much of the creative, above-the-line work can be done anywhere, and the few who need to be on location, such as directors or leading actors, can be flown to location. Below-the-line labor is more replaceable and not transported with production. As a result, runaway production tends to benefit above-the-line workers who travel with production, while below-the-line become more dependent on the mobile production attraction. In the end, this has helped solidify labor groups, including unions, in working with the MPAA and other associations to expand film subsidies, usually for their short-term benefits, but ultimately for the longer term and larger benefit to non-replaceable talent--such as famous actors and names used for advertisement--but especially for the leading Major Studios.

Runaway productions greatly helped the Major Studios combat costs and labor power concentrating in Hollywood. Even during the peak of the Studio Era, 
where film and theater concentration was at its highest, there were infamous clashes with unions representing numerous sectors of Hollywood production. The focal point of these Union-Studio battles was in the 1940s (Spaner, 2012). This was the Black Friday battle, which started with picket lines led by the Conference of Studio Unions, which shut down productions at Major Studios, such as Warner Bros. While many were injured in the fight, many more were arrested and fired. Despite initial concessions on wages, the Major Studios still retained much concentrated power and state support; ultimately the Conference of Studio Unions was disbanded and incorporated into the much more malleable International Alliance of Theatrical Stage Employees. As the Majors retained their monopolistic hold on all sectors of film distribution, production, and exhibition, they had more ability to placate or end any strong unions. However, as that power faded in the decades following the Paramount Decree, the 1948 antitrust suit that ended film studios from owning and monopolizing theaters, the Majors increasingly focused on international markets. This was done both to recoup their revenue beyond the growing competition of indie studios, but also to lower production costs and their dependence on Hollywood labor.

It is thus with the Paramount Decree that Runaway production became an institution for the Majors, as well as a tool for retaining control after losing theater investments (Scott, 2002; Christopherson and Storper, 1986). With the loss of assured exhibition for all films, the so-called "Fordist" production of the Studio era necessarily ended. No longer would production be churned out like a factory, with overlapping sets, actors, and plots. Without control over exhibition, the large, 
integrated, factory-like studios became a larger liability for the Majors. The Decree, as a result, helped bring about what Christopherson and Storper (1986) call Flexible Specialization. This term refers to the creation of a specific and particular product, as opposed to mass production of general products, with the means to quickly change or refocus effort and equipment, usually done through a network of smaller producers. Film was especially conducive to this manner of production, especially as the mass production of the Studio Era gave way to an increasing reliance on mobile production. ${ }^{48}$ Much like other transnationalized industries, the Majors could use studios, labor, and locations around the world in a replaceable fashion, thus developing the network of smaller producers needed for Flexible Specialization. Not owning studios or permanent employees in these varied locations allows the Majors to quickly shift location and change productions, while the ownership of Intellectual Property and ability to finance Blockbusters allows the generation of specific and unique products. It was then up to the disposable locations to attract these productions through skills, infrastructure, and subsidization. The start of this Subsidization System had its strongest expression in runaway production leaving Hollywood for the Canadian West Coast, still relatively nearby.

\footnotetext{
48 It was likely that the monopolized production and exhibition of the Studio Era itself was resulting in the particular style of product and consumption. However, as broadcast television was increasingly competing with theaters the days of mass production for film were likely already numbered. The spectacle of the big screen, along with selling points such as "cinerama," "cinemascope," and early on the use of sound, would no longer be enough to get customers out of the house once they had a television. As a result, specialization of film itself was increasingly necessary to draw a crowd that was becoming content with cheaper television production, resulting in increased budgets and greater need to reduce costs. See Crafton (1999) for a history of the early role of technical innovation in film and Seabury (1926) for a history of Major Studio control prior to runaway production.
} 


\section{International Subsidies: Canada and Europe}

As Davis and Kaye (2002) reveal, Canadian theaters have always been dominated by the larger market to the South, to a degree that the Canadian market has been integrated enough to be considered as part of the "domestic market" by the MPAA. Canadian films generally make up $5-10 \%$ of the "Domestic" revenue box office, of which Hollywood films "account for approximately 90 percent" (Davis and Kaye, 2002). By the 21 st century, Foreign (American) productions in Canada even made up $85 \%$ of Canadian film exports (Davis and Kaye, 2002; CFTPA 2008). While Montreal and Toronto hold their own in film production, both in foreign and domestic productions, it is Vancouver on the less populated West Coast that receives half of production spending (Davis and Kaye, 2002). While this is in part due to geography and proximity to Hollywood, the politics of International Runaway Production along with the subsequent Subsidization System, is the largest factor.

Prior to the 1990s, Canada, much like other states, was wary of Hollywood and thus focused their film subsidization schemes on protecting culture and promoting domestic art. In the 1960s much of Canadian film production came from the more populated East Coast, resulting in British Columbia on the West lagging behind both in media consumption and production, resulting in an underdeveloped cultural industry. As such, as Hollywood increasingly looked toward foreign productions as a means to lower budget costs and circumvent local unions, British Columbia saw the opportunity largely in terms of "regional industrial development" and a means to "a way to attract immigrants, capital 
investment, and tourists" (Gasher, 2002). As such, unlike other programs that were at least initially directed toward domestic production and culture, the British Columbia subsidy scheme was specifically designed to target mobile Hollywood productions and develop a local industry out of that relationship (Gasher, 2002). As much of the Canadian media consumption in British Columbia came from the East Coast the likelihood of developing a fully independent local industry was already low and thus the larger and closer Studios of Hollywood had more to offer.

Initially as Vancouver began to take larger shares of film production in Canada, national subsidies continued to focus on developing and protecting cultural industries, with much of these funds going to the more developed media industry on the East Coast. These cultural protections continued into the 1990s, including cultural exceptions being a large part of Canadian goals during NAFTA negotiations. Much of Europe was facing similar conflicts with Hollywood, both over cultural concerns as well as keeping subsidies to domestic studios rather than Hollywood. However, it was the active and direct solicitation of Hollywood Majors by British Columbia's subsidization scheme that shaped how governments would attract runaway production in the future. By the late 1990s state-to-state competition for Hollywood productions began to take shape. This is concurrent with Canadian national film subsidies shifting from focusing on cultural to economic indicators, tacitly opening up these funds to foreign productions. EU film subsidies also began to downplay cultural concerns to the advancement of immediate and short-term concerns, as did individual US states 
who began to rely on subsidization to compete for jobs and growth in their local industries. By the 21st century, an entrenched International Subsidization

Scheme had been developed, based entirely on neoliberal logic of open markets, transnational production, and supply-side support, to the disproportionate benefit of the Multinationals of the MPAA.

\section{Europe}

The European film industries followed a fairly similar experience to Canada. Though not included in the "Domestic Market" as Canada is, Western Europe saw early dominance from Hollywood. However, while European subsidies would sometimes reach Hollywood productions, the goal in attraction of runaway production, as pioneered by British Colombia, only reached Europe once the International Subsidy system was already in full swing. Many Western European states initially had a more robust domestic film industry to protect, with more independence compared to Canada. As a result, there had consistently been stronger political support to attempt to rebuild a competitive industry. This was especially true following WWII, when Hollywood was very much dominant across the Atlantic. In perhaps an early demonstration of the transnationalism that neoliberalism would soon bring, the mixture of protectionism, subsidies of European industries, and reliance and dependence on American products and firms, actually helped lead to Europe eventually joining the Subsidy System.

The fragility of the economies in Europe following the war left many industries with the precarious situation of needing immediate goods while also needing to rebuild competitive industries. For film, even for countries like France 
as an inventor of the medium and especially concerned with culture and language, this meant a relatively wide opening for American films for European consumers, whose demand could not yet be met domestically. With this vulnerability and dependence, there were few ways for these states to combat the power of Hollywood. These included direct protection of domestic film production that conflicted with the post-war trade system; subsidization of domestic film, initially around cultural products; limitations on the repatriation of profits by foreign producers, to force local investment in production; and integration of local production into the Hollywood system, to attempt to move up the hierarchy rather than exit it.

This interaction of means of production, which ended up feeding the industry hierarchy rather than opposing it, can best be seen in the operations of the British film industry and development, which has always been more closely integrated with the American industry. While London participated in similar means to revamp their film industry following the war, they also were more accepting of integrating their industry into the larger and more global American multinationals. As early as the 1950s, Britain set up a subsidy scheme known as "Eady Pool of Funds." This was a tax on movies, which would then be given as a rebate to film productions that were considered "British" (Lev, 2003. p. 153). However, due to American financing and runaway production many of the subsidies went to American productions or co-productions with American financing (the latter has become an increasingly important and growing trend in today's system). The "Eady Pool "was of decisive importance in persuading U.S. 
producers to shift operations from Hollywood to London" (Bernstein, 1960, Quoted in Lev, 2003, pp. 153). Even the measures stopping Hollywood from repatriating profits back to America ended up supporting transnational productions, as the capital stuck in European countries was used to fund productions there, helping to blur their nationality and thus their access to these early subsidies.

As Britain saw economic success with its willingness to integrate into Hollywood's international system, as well as supporting the Hollywood system politically and economically, other states began to open up to such competition as well. "France and Italy had similar, but less generous, subsidy programs. Though the original intent had been to support national film producers, Great Britain, Italy, and France were willing to subsidize Hollywood film companies as well in order to stimulate film industry investment and employment" (Lev, 2003, pp. 153). As these production markets increasingly become infiltrated by Hollywood, by $196040 \%$ of "...movies financed by Hollywood majors were shot overseas" (Monaco, 2003, pp. 14). Most of this was in the UK with two-thirds of their films having Hollywood financing. However, Italy and France, known for strong cultural protectionism, were integrated into the production as well, with 3 out of every 10 French productions having Hollywood financing (Monaco, 2003). In 1962, Hollywood got \$5 million in subsidies from Britain, Italy, and France alone (Monaco, 2003, pp. 12). 


\section{Expansion of Subsidies: American States}

Despite Europe inadvertently subsidizing some Hollywood productions, the early adopters of the model to attract runaway productions were still British Columbia, with American states following soon after--a process which helped to further consolidate the International Subsidization System. This exponential expansion can be seen in the chart below. This immediate adoption of subsidies by other states was likely a result of relative success in attracting Major productions for the early subsidizers, such as British Colombia. However, the early successes were heavily due to the lack of competition from other locations. As other governments developed their own subsidies to attract production, these benefits eroded while the expectation to fund production continued. Even existing film centers, such as California and New York, adopted subsidizing local productions, and themselves have allocated some of the largest funds to stop production from leaving. Others, such as Florida, Georgia, and Louisiana, like many of the newer countries to the International Subsidy System, were attempting to create a new local film industry, ostensibly one that would eventually be self-sustaining, presumably on the assumption that their own subsidies would be able to sustain localized benefits despite rising competition.

\section{Number of Incentive Programs and Funds ${ }^{49}$}

\begin{tabular}{|l|l|l|}
\hline Year & $\begin{array}{l}\text { Number of U.S. States with Film } \\
\text { Incentive Programs }\end{array}$ & $\begin{array}{l}\text { Incentive Amounts } \\
\text { Offered }\end{array}$ \\
\hline
\end{tabular}

${ }^{49}$ See McDonald (2011) for 1999- 2011 figures and Bishop-Henchman (2016) for the 2012 figure. 


\begin{tabular}{|c|c|c|}
\hline $\begin{array}{l}1999 \text { \& } \\
\text { earlier }\end{array}$ & 4 & $\$ 2$ million \\
\hline 2000 & 4 & \$3 million \\
\hline 2001 & 4 & $\$ 1$ million \\
\hline 2002 & 5 & $\$ 1$ million \\
\hline 2003 & 5 & $\$ 2$ million \\
\hline 2004 & 9 & \$68 million \\
\hline 2005 & 15 & $\$ 129$ million \\
\hline 2006 & 24 & \$369 million \\
\hline 2007 & 33 & $\$ 489$ million \\
\hline 2008 & 35 & $\$ 807$ million \\
\hline 2009 & 40 & $\$ 1.247$ billion \\
\hline 2010 & 40 & $\$ 1.396$ billion \\
\hline 2011 & 37 & $\$ 1.299$ billion \\
\hline 2012 & 40 & $\$ 1.4$ billion \\
\hline
\end{tabular}


Louisiana was one of the first states to adopt film subsidies to develop a local production industry. Having an already established a cultural and tourism industry, as well as a temperate climate to allow shooting year-round, Louisiana became a sensible choice for film production. But their entry into subsidy competition was as much about attempting to attract existing production away from other locations, as it was of creating new production. This was followed by a New Mexico scheme, which became part of the first wave of developing a competitive subsidization among US states (Thom, 2016). Although these schemes had the intent, much as the British Columbia scheme pioneered, to focus on economic benefits opposed to the classic subsidies for culture, they had not reached the financial extent and broad participation that made up a fully competitive system until the 2000s (See amount offered between 2003 and 2004). As Tannenwald (2010, pp. 3) reveals:

Until 2002 state film subsidies were limited in scope. A few states offered film producers small credits against income taxes, deductions from taxable income for losses incurred in production, or loan guarantees. Other subsidies were confined to the provision of public services at no cost (for example, police details, ready access to public lands, assistance in identifying locations, and expedited permitting), or exemption from sales tax on purchases of goods from local vendors and from hotel and lodging taxes for employees working on an in-state movie shoot. These subsidies may or may not have been the best possible use of funds, but they were low-cost and therefore relatively harmless. 
Preston, in elaborating further on this first, more limited phase of subsidization during the 1990 s and early 2000 s and specifically using Louisiana as a case study, wrote that "For the first ten years of its existence [starting in 1992], Louisiana's program underperformed (Grand 2006, 792-793), and any film production that had been lured away from Los Angeles or New York typically went to Vancouver, British Columbia" (Preston, 2013). By the late 1990s competitive subsidization began to be seen as essential for maintaining a decent film industry, driving many other states to compete with their own subsidies. By 1997, the Canadian government began remodeling their national film subsidies around their perceived economic interest, taking their cues from the early success of British Columbia and Vancouver. Likewise, Hawaii (in 1997), Missouri (in 1999) and Oklahoma (in 2001) developed their own systems, and Louisiana and New Mexico once again followed the Canadian model and substantially expanded their subsidies in 2002 (Thom and An, 2017).

While the number of competing subsidies expanded across North America, and later internationally, the subsidies expanded also in amount of funds and in how they were offered. Away from the indirect subsidies described by Tannenwald for early schemes, subsidies have since developed into direct cash transfers. The varied and indirect subsidies include those for housing, finding skilled workers, or even location scouting, but the more sought-after and costly subsidies have been tax credits. These subsidies can be divided between transferable tax credits and refundable tax credits (Thom, 2016). Transferable tax credits are tax waivers offered to a production company for a set amount, usually 
a percentage of production costs, which can then be sold to another party for a discount on the waiver amount. Thus, the purchaser receives a discount on their potential tax payment, while the producers receive immediate cash to offset production costs. While transferable credits offered immediate cash, refundable credits offer a direct transfer of cash to the producer for the full amount of the credit (McDonald, 2011). These aggressive and large subsidies have, according to Thom, had modest impacts. Employment was most affected by transferable credits, while wages were most affected by refundable credits, but for both affects the benefits were short-term. To view the extent of the long-term problems, dependence, and entrenchment of the corporate oligopoly it will help to examine some case studies of US states, followed by an analysis of the global subsidy system. Here I will examine three of the larger domestic subsidy schemes--one to retain and recoup production (California), one that failed and ended (Florida), and one with strong and continuous expansion (Georgia).

\section{Florida}

Florida is an interesting case in examining its subsidy program due to the extent, length, and relative large-scale size of their program, which was later discontinued. Florida was one of the possible locations for the first movie moguls, as Jacksonville was scouted along with Hollywood due to its climate. Florida also possesses relatively strong production in Orlando and Miami, both as an on-site

location for production as well as a location for Spanish-language television. As a Southern and "right to work" state, Florida also has weak unions, which 
according to neoliberal proponents (including the MPAA itself) should make it a frontrunner for a successful development of film infrastructure. As such, compared to many of the other participants in production attraction and subsidization, Florida should have been one of the stronger candidates for successful development of a strong local film industry. The fact it did not have success will help illustrate both the inherent problems and limitations of subsidies, as well as the contradictions in a competitive subsidy system, whereby permanent subsidies become necessary.

Florida started its initial film incentive program in 1993, following soon after the Louisiana program. And, much like Louisiana, this early Florida program was missing the direct cash transfers described above, only offering the smaller incentives that were common at the time. This still had the goal of attracting mobile film production, but had a much smaller impact, both in budget and effect. Initially this incentive program was developed under the Florida Entertainment Commission, but it was reshaped into a specific office, The Office of Film and Entertainment (OFE) in 1999, within The Department of Economic Opportunity (Wilcox and Krassner, 2014). The transition into the OFE occurred with the general normalization of expanding subsidies, along with the inclusion of direct cash subsidies, again following along other expanding models in North America. Despite Florida still getting a relatively early start, already at its founding in 1999, the OFE had received a budget expected to grow year upon year, which would be necessary to compete with a sizable number of subsidy programs. 
As with other subsidy schemes, to legitimize the program as not simply corporate welfare but as jumpstarting local industry, the original legislation authorizing the program had a mix of language emphasizing the creation of production infrastructure and attracting production from other regions. It is interesting to note that the OFE website today has a much stronger emphasis on attracting production from other regions, rather than generating new production in Florida. Like other schemes, the proponents of this excessive spending also emphasize the indirect multiplier of film tourism, an easy target for the economy of Florida. Once again the influence of the Major studios and the MPAA is evident in the drafting and implementation of the film subsidization programs. The MPAA is a member of local film associations, in particular Film Florida, which, like lobbying projects in other states, publishes the purported economic benefits of subsidies, with a special emphasis on tourism, due to the indirect and thus unfalsifiable connection--more tourism becomes an anticipated outgrowth of locating film production in the host state. News organizations and lobbying groups reference these MPAA reports when providing data pertaining to the efficacy of subsidies.

As the budgets for competitive subsidies ballooned in the first decade of the 2000s, by 2010 the Florida Legislature passed The Entertainment Industry Economic Development Act, which allocated $\$ 242$ million to the OFE to incentivize and attract film production to Florida. This budget was designed to cover a five-year period, after which it could be supplemented with more subsidization. This, however, led to failure and the eventual dissolution of the 
subsidy budget for two reasons. One, although high in total, spread over 5 years, this would have been relatively small compared to the leading subsidizing states, such as Georgia and California. As such, Florida was likely hedging its location and natural attraction, but having a smaller than average budget within a race to the bottom would likely have been unsuccessful, given the pattern of other halfsupported programs in South Dakota and Indiana, which did little in the way of generating an independently sustainable local industry (Thom, 2016).

However, the program in Florida was not terminated due to tepid responses to a smaller than average budget, or after the number of programs diluted the success of early adopters. Rather the end to the program came relatively quickly as the money dried up due to the lack of a spending cap per project--an outcome which reveals the propensity toward corruption and lack of accountability inherent to such programs (Thom and An, 2017). Without a cap, the cash ran out "nearly immediately" due to the money being made available on a first-come-first-serve basis (Walser, 2016). Cash was given out to any production that qualified, rather than based on an analysis of cost and benefits to measure whether or not such spending produced lasting infrastructure or recurring production. In subsequent years supplemental additions were given to the budget, but without a fundamental change these too were quickly depleted in the same manner. By 2013 no supplements were added, and the Florida subsidy system was out of funds.

The limited effects and quick depletion of film subsidy programs in Florida have been criticized for a loss of jobs and production in the state. Interest groups, 
including "Enterprise Florida," the state's economic development arm that incentivizes companies, and "Visit Florida," the state's tourism marketing arm, had advocated recreating a subsidy system to retain possible production, utilizing the rhetoric of defending Florida jobs (Irwin, Oct 20, 2017). Two leading groups in this effort are Film Florida and COMPASS Florida. Film Florida is a lobbying group, representing numerous groups including film schools, local producers or associations, and even Universal Studios. Film Florida is very much the local component to the MPAA, and acts to promote local legitimacy for the maintenance and expansion of a film subsidy system in the state. Like in other states, Film Florida has been a participant in commissioning favorable reports with which to lobby politicians and provide the public with positive figures pertaining to the film subsidy program. Film Florida also works in partnership with the OFE, but has also pushed for taking over the subsidy fund as a public-private partnership, citing lack of marketing skills by state agencies (Film Florida, 2013). COMPASS Florida is likewise representative of related film unions as well as small businesses.

To keep up with the ever-increasing subsidies among competing states (especially neighboring Georgia), the suggestion was for $\$ 1$ billion in subsidies (Hanks, January 29, 2014). As of now, the trade and labor organizations have put forward a more modest proposal for a "Florida Motion Picture Capital Corporation." Rather than offer subsidies through cash transfers, the "Capital Corporation" would operate as a "more traditional investment mode" and theoretically make money, though where initial funds would come from is unclear 
(Irwin, October 20, 2017). However, in step with criticisms of corporate welfare, greater emphasis is placed on allocating resources based on "...which projects create the greatest number of high-wage jobs..." (Taddeo, 2018). In the meantime, local municipalities have started to get in on subsidies with Miami-

Dade creating a $\$ 100,000$ local subsidy program (Hanks, July 19, 2017). Miami has emerged as a focal point for the Florida film subsidy system, as South Florida had received 78\% of program funds by 2013 (Hanks, January 29, 2014).

\section{Georgia}

As some states see little hope in competing with innumerable locations and massive subsidies (North Dakota) or have otherwise ended their subsidy system with failure (Florida), Georgia is commonly held up by proponents of the system as an example of success, with a relatively strong production industry in an unlikely state, concentrated around the capital of Atlanta. In recent years Georgia has found itself in competition for the leading destination of production for the highest grossing films, along with California, New York, and international (and strongly subsidized) locations of Canada and the UK. However, unsurprisingly, it finds itself with one of the highest budgets for its subsidy program, trailing only New York. Having spent multiple billions over the life of its program, Georgia can attribute its "success" to entering this inevitable "next tier" of cash transfers. Thus, while Georgia may compete with residual strength (but still large subsidies) of California, and the giant subsidies of New York, it does so 
without caps to spending, without emphasis on independent productions and new projects that California emphasizes, and without a focus on local labor.

With loose requirements from producers and some of the highest and most friendly incentives, Georgia is able to match the leading domestic locations of California and New York, and then surpass them through cheaper labor and locations (especially compared to New York, which can partially explain their high budget). Georgia is also commonly seen as being the leading competitor for "southern" locations, beating out Louisiana, and likely one of the reasons for Florida to drop out of the subsidy race. The movie Live By Night is a great example, being set in Ybor City, Florida, yet being shot in Brunswick, Georgia thanks to the $30 \%$ tax credit offered (Irwin, October 20, 2017). Other Floridabased directors have discussed moving future productions to neighboring states such as Georgia and Alabama, either from a necessity to compete in a low production cost environment or to also generate further pressure toward an expanded incentive program (Boedeker, November 30, 2014).

While the success of Georgia is heavily a result of attracting existing production, it also reveals other problems with such schemes. Georgia has faced a shortage of film crews (McWhirter and Schwartzel, 2015). Despite offering no subsidy cap on salary, as well as offering incentives to non-resident workers, specifically to attract production as opposed to generating it, the state has found it difficult to retain such mobile labor and investments. Due to these limitations, the large Georgia program has been in the crosshairs of the same organizations that helped end the Florida program, including libertarian Koch groups. Georgia 
has, instead, doubled-down, increasing their budget, thanks to overstated claims of economic benefits from the program, usually from reports again commissioned by MPAA and local partners. These reports have been utilized to prolong and expand such programs by greatly overstating their benefits for the state using an outdated and fairly arbitrary multiplier to calculate program impacts. The multiplier effect (the compounding effect of incentive money being put into the local economy) itself becomes overstated by using a very optimistic assumption of how much money from film production stays in Georgia. In fact, much of the subsidized costs are not permanent nor are they limited to local labor. "Georgia's $30 \%$ credit is not only more generous than that of most states, including California's; it also allows producers to count salaries of directors and actors in addition to below-the-line crew as part of their qualified expenses, as long as the payment is for work performed within the state" (Johnson, 2015).

\section{Studio Advertising in Georgia:}

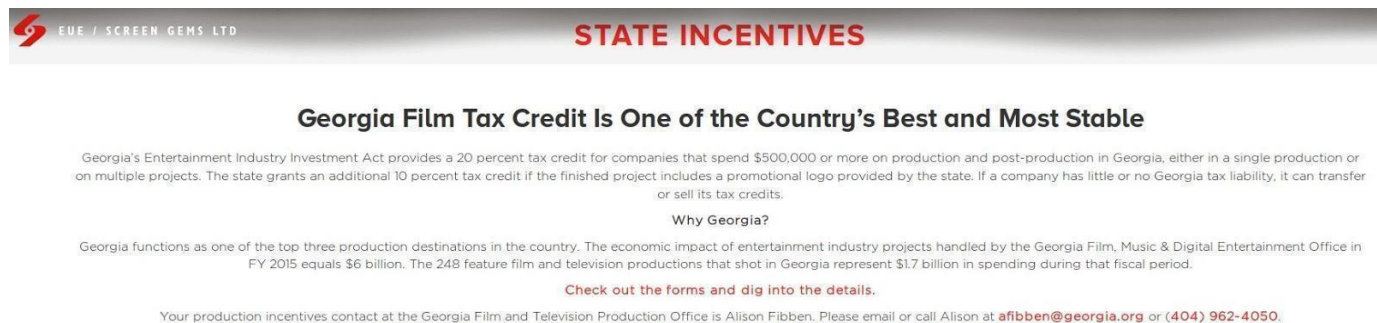

\section{Georgia conditions for benefits:}

- 20 percent base transferable tax credit 
- 10 percent Georgia Entertainment Promotion (GEP) uplift can be earned by including an embedded Georgia logo on approved projects and a link to ExploreGeorgia.org/Film on the promotional website

- $\$ 500,000$ minimum spend to qualify

- No limits or caps on Georgia spend, no sunset clause

- Both resident and non-resident workers' payrolls and FICA, SUI, FUI qualify

- No salary cap on individuals paid by 1099 , personal service contract or loan out. Payments made to a loan out company will require six percent Georgia income tax withheld

- Production expenditures must be made in Georgia to qualify from a Georgia vendor

- Travel and insurance qualify if purchased through a Georgia agency or company

- Original music scoring eligible for projects produced in Georgia qualify

- Post-production of Georgia filmed movies and television projects qualify if post done in Georgia

- Development costs, promotion, marketing, license fees and story right fees do not qualify

\section{California}

Unlike Florida and Georgia, California has been much more reactionary in response to the subsidy system. For much longer local producers and unions 
have been complaining of investment flight and the loss of jobs and wages. The earlier experience for Californian film workers, along with L.A. being the "home" location of the Majors, makes it an especially important case study. California may have not been the originator of the subsidy system (Canada and Louisiana) but it was an early exercise for the MPAA to learn how to increase dependency within the industry, generate industry control on the supply-side as well as through labor flexibility, and to use the Hollywood location to reinforce the Majors' position in the industry hierarchy. "The industry trade group quarterbacked the campaign to stop 'runaway production.' The MPAA rounded up a broad coalition, including chambers of commerce, labor groups, and cities up and down the state. Offering a bonus for productions outside Los Angeles helped win over Northern California lawmakers, who have traditionally opposed tax giveaways to a Southern California industry" (Maddaus, 2014).

The Majors are not only the major utilizers of mobile productions and subsidies, but also a leading voice in expanding those subsidies. Rather than assisting in the development and expansion of local film production industries in California, the systemic nature of subsidies, all supported by the MPAA, end up canceling each other out and largely operates to further the transnationalization objectives of the Major Studios. As seen in the following figure, labeled "Employment by State," California, and in particular L.A., continues to be the largest production center for film. As with all subsidy schemes, it has been suggested that one-third of the subsidized productions would have remained in California anyway, weakening the case for subsidization as a necessary 
contribution for retaining film industry investment and jobs in the state (BishopHenchman, 2016).

25. Employment by state ${ }^{50}$ :

\section{More Than Half of U.S. Motion Picture Production Employment Is in California ${ }^{a}$}

2015

Florida, Georgia,

Louisiana, and Texas

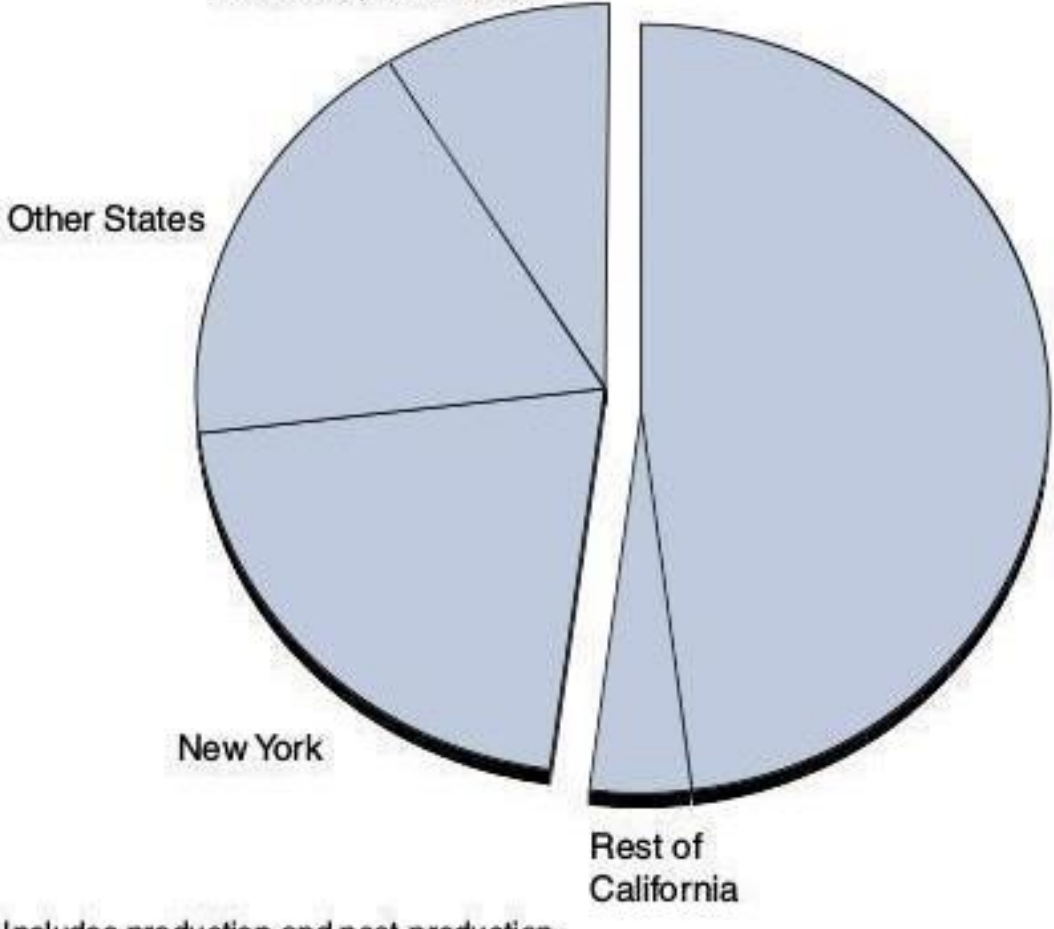

Los Angeles County

ancludes production and post-production.

${ }^{50}$ Weatherford (2016) 
Although California has long been experiencing the process of "runaway" film production, the state had been relatively slow in participating in the subsidy system. This was likely due to the already existing local infrastructure and supply networks for the industry. Because of the obvious narrow benefits of such types of subsidies, the need to legitimize both infrastructure and temporariness seen in other states did not quite work in California. It is only with the entrenchment of the subsidy system in other states, did California become a full-blown participant in the International Subsidization system in late 2009, which has expanded in recent years as California has become one of the leading domestic state subsidizers.

It was in 2009 that the political and economic power of the Majors in California bore institutional fruit, with the creation of a $\$ 100$ million "Tax Credit Program 1.0" under the California Film Commission. This budget cap was expanded in 2015 to $\$ 330$ million (with program 2.0), making California one of the leading participants in competitive subsidies. Like the suggested "Film Corporation" in Florida, Program 2.0 has a large focus on project selection based on jobs, and with a more diverse project allocation, with $40 \%$ devoted to TV Series, Pilots, and Television Movies; 35\% to Non-independent Films (read: Majors); $20 \%$ to Relocating TV Series; and 5\% to Independent Films. The strong emphasis on TV series (60\%) means production that provides more stable and permanent jobs, but also is connected to the majors and owners of the distribution-channels for such production (Maddaus, 2014). The fact that $20 \%$ of funds are specifically allocated to relocation of TV series also reveals the growing 
focus on relocation for such programs, rather than the creation of production that would not otherwise have existed.

McDonald (2011) argues for a national subsidy system, as the state subsidy systems, which again are some of the leading subsidizers in the world, do not create new production, and rather result in a race-to-the-bottom subsidization of existing production. While this would help reduce the race to the bottom domestically, the Majors would still have options to exploit the international system, and location choice would continue to operate on merit second and cash transfers first. The largest to lose out would be local indie producers and labor, unless they themselves are mobile. Such a national system would benefit Hollywood and California, and disrupt existing dispersed production infrastructure, such as from Georgia, while the Majors would continue to benefit as the international subsidy competition would continue. 


\section{Largest Box Office Revenue Film Production locations ${ }^{51}$}

\section{NUMBER OF TOP 100 DOMESTIC FILMS PRODUCED BY LOCATION}

\begin{tabular}{|c|c|c|c|c|}
\hline PRODUGTION GENTER & 2016 & 2015 & 2014 & 2013 \\
\hline Georgia & 17 & 13 & 8 & 9 \\
\hline UK & 16 & 15 & 12 & 9 \\
\hline Canada & 13 & 11 & 7 & 16 \\
\hline California & 12 & 14 & 21 & 16 \\
\hline Louisiana & 6 & 9 & 6 & 15 \\
\hline New York & 6 & 7 & 12 & 4 \\
\hline Massachusetts & 5 & 3 & 2 & 4 \\
\hline Australia & 4 & 1 & 2 & 2 \\
\hline New Mexico & 3 & 2 & 1 & 2 \\
\hline France & 2 & 1 & 3 & 2 \\
\hline Florida & 2 & 0 & 1 & 1 \\
\hline New Zealand & 1 & 1 & 1 & 2 \\
\hline Malta & 2 & 0 & 0 & 1 \\
\hline Michigan & 1 & 0 & 2 & 1 \\
\hline Italy & 2 & 0 & 0 & 0 \\
\hline Oregon & 1 & 0 & 0 & 0 \\
\hline Pennsylvania & 1 & 6 & 1 & 1 \\
\hline Rhode Island & 1 & 0 & 0 & 0 \\
\hline Japan & 1 & 0 & 0 & 0 \\
\hline Hungary & 2 & 2 & 0 & 0 \\
\hline Hawaii & 1 & 1 & 0 & 0 \\
\hline Connecticut & 1 & 1 & 0 & 0 \\
\hline
\end{tabular}

\section{International}

Some countries such as France, whether due to cultural protectionism or relative size of the market, had been able to build domestic industries semi-

51 (McDonald, 2016) 
independent of the Majors, even if they do participate in subsidies. Germany, however, is an especially interesting case, as it has a relatively strong industry, decent international reach from its movies, and a history of film and cultural protection comparable to France, if not quite as strong. Despite this, Germany developed a reputation of having its subsidy system, which had initially been developed to strengthen the domestic industry, exploited, especially by the Majors of Hollywood. With subsidies as high as $55 \%$ from federal and state (Länder) sources (Jansen, 2005) foreign producers accessed these "domestic" subsidies through co-production deals with domestic entities, much as was done earlier in Britain. While Germany has since cracked down on these "in name only" co-productions, the financing deals that helped the majors integrate and penetrate the European production markets, have become increasingly commonplace and continue to be a key component of the International Subsidy System.

Lara Croft: Tomb Raider provides an excellent example of utilizing multiple locations, pre-sales, subsidies, and partners to reduce risk on a strong budget. With a budget of $\$ 94$ million, according to Epstein (2005) the main production company, Paramount (Viacom), only paid $\$ 7$ million, leaving $\$ 84$ million from other contributors, including state subsidies. Germany is a prime example of subsidy abuse by transnational corporations, as the conditions in its Film Funds did not reflect the social utility of either jobs for locals, protecting local culture, or developing a domestic film industry. Germany also had some of the largest subsidies: 250 Million Euros in 2005. Instead "German law simply requires that 
the film be produced by a German company that owns its copyright and shares in its future profits" (Epstein, 2005). Paramount's German partners were KFP Produktions GmbH \& Co. KG, whose only credits on IMDB are Tomb Raider and licensing of Tomb Raider footage, and Tele München Fernseh Produktionsgesellschaft (TMG), which moved into domestic TV production after these film subsidy loopholes were cut.

The notoriety and ability for abuse of German subsidies were quickly integrated into the general operations of Hollywood. As Lindsey (2006) notes, "No wonder then that this source of funding was commonly referred to in the boardrooms of LA as "stupid German money" (quoted in Cooke, 2007). As the Subsidy System was still developing in the early 2000s, the German exploitation was especially notable. This brought the German Chancellor's Grand Coalition to make "pulling the plug" on these funds one of their first actions in November 2005. While some funds were cut with an ostensible goal toward "New German Cinema" rather than Hollywood productions through German entities, this process coincided with the entrenchment of commercially driven market subsidies. As such, while ostensibly new subsidy programs would focus on arthouse films and around director visions, they were designed for German and European films to compete commercially on an international scale (Cooke, 2007). With the EU being a driver toward commercial subsidization, and Germany retaining both national and state subsidy programs, this reliance on market-driven subsidies (as opposed to a cultural and art criteria) leads to a contradiction that does little to halt the race-to-the-bottom effect of subsidies. As 
Europe focuses on local commercial films they can still partner with the larger productions from Hollywood as the Majors focus more on globally targeted blockbusters.

As a result of Germany's unique position relative to its smaller neighbors,

Germany has plans to expand its already large and numerous subsidy programs (Deutsche Welle, 2017). However, with the clear strength of Hollywood Majors and the international entrenchment of subsidy systems, this increase of subsidies is without the traditional focus of cultural concerns. As such, the results have been to entrench the oligopolistic position of the Majors by contributing to a twotiered system with two characteristics: 1) European filmmakers are subsidized to compete on the "medium" level film market, as Hollywood increasingly focuses on the global blockbusters. This allows leading European producers to break through the idiosyncratic local market and increasingly compete internationally, essentially creating a second-tier mini-major status. 2) Continue to participate in attracting large investments from Hollywood blockbusters, thus sustaining the system and accepting a 2nd tier position in the oligopolistic hierarchy.

\section{Consolidation of a Global System}

As states began to openly compete for what was a finite amount of production spending and mobile projects, the efficacy and utilization of such schemes began to become questioned. While the debate is largely dispersed between cost of subsidies on the one hand and short-term versus long-term gains on the other, what is clear is that the Subsidization normalization during 
this period coalesced with the reconsolidation of the Film Industry into Mass Media Conglomerates and, as a result, a dramatic increase in both the political and the economic power of the MPAA cartel, which had a strong role in developing this system. Even within general neoliberal pressures to increase competitiveness and open markets, the dependency generated by the Majors and the MPAA put film in a unique position. As such, of the total $\$ 80$ billion of direct subsidizations to corporations from Washington and US states in 2011, $\$ 1.455$ billion was for the film industry, making it one of the most subsidized industries. As mentioned, per job/employee film subsidization has been about $50 \%$ higher than the better known and heavily subsidized auto industry.

Looking at U.S. state subsidies Thom and An (2017) argue that the strongest reason for starting a subsidization program revolves around poor economic conditions as well as high unemployment. This is based around the intention to provide employment relief, even if the jobs are temporary, as well as help diversify the economy. Developing infrastructure for an eventual selfsustaining and attractive production market is commonly cited to defend subsidization schemes, both on the basis that they are only necessary temporarily but also provide long-term growth (Thom and An, 2017; Davis and Kaye, 2010). On a more short-term analysis is an examination of the Economic Multiplier effect of bringing in investment and labor. Even if temporary the defense lies in utilization of local hotels, restaurants, supplies, and workers, who, even if short-term and below-the-line, themselves feed into the local economy. 
Some proponents even go so far as to claim the cost of the subsidies can be below the increased tax revenue from attracted investments, but perhaps one of the more interesting cited benefits of subsidies, and one pushed by the MPAA, especially for areas unlikely to develop a substantial local industry, is the promotion of "film tourism." Also called "cultural tourism," this is an attempt to expand the extent of economic multiplier of subsidies. Especially for locations that are already attractive for tourism, and for the same reasons attractive for location shooting, this type of analysis makes an easy target to hold up as a benefit of subsidized production. Louisiana, one of the states aggressively offering production subsidization, is a good example of this. A 2015 report funded by the MPAA and local association, Louisiana Film and Entertainment Association (LFEA), offered the bold claim that film and television tourism (thanks to production credits) generated up to $\$ 1.238$ billion in personal income (HR\&A, 2015). This is in comparison to the same report's estimation that the credit brought $\$ 1.039$ billion of production spending, and a total of $\$ 10$ billion in tourist spending. This claim comes from comparisons with Lord of the Rings tourism in New Zealand, however with an emphasis on such local TV productions as Duck Dynasty and Swamp People.

Beyond the grandiose claim of benefits is the important aspects of the creation of such reports and their purpose. The MPAA partners with numerous local associations and small producers (such as the LFEA in Louisiana) for both a local and broad-based coalition to lobbying local politicians. These reports, which are naturally exaggerated to the benefits of not only film production but 
also direct subsidization (and squarely contradict many academic conclusions), are developed in numerous markets, both domestic and international. While this can be seen as direct lobbying, or at worst regulatory capture and corruption in many cases, it also has a larger systemic benefit for the majors when examined holistically. First is the clear race-to-the-bottom pressure to attract blockbuster production. Second is the building of political relationships with local actors helping to support such subsidization. Many local producers and labor groups, such as unions, support the Majors by working with the association in lobbying politicians, such as seen in the Louisiana report. The power relationship, beyond immediate dependence on Hollywood spending, is that these groups insist on reinforcing the structure of their dependence, as the MPAA develops such relationships in numerous competing locations. When these groups lobby local politicians, the coalition is legitimized by local interests, supported by the big money promotion by the Majors, and influenced by and reinforcing the norm of film subsidies as an economic solution. As Thom and An (2017) argue, politicians need to appear to be "doing something," making this system of dependence and competition among governments, unions, and local independent producers a boon for the multinational and mobile MPAA studios.

When examined holistically a group of workers, unions, producers, local associations, and politicians support the interests of the major multinationals due to their own perceived dependence. These four levels of actors--workers, local producers, politicians, and the Majors--all assist in reinforcing one another through their own developed ecosystem. Local filmmakers get access to funds 
with and without working with larger studios. Film industry workers are forced to rely on temporary job projects or to face the need to migrate with the mobile projects to locations with stronger subsidies. Politicians receive funds for government subsidization and can then claim that they "did something" to help local industry. The Majors continue to use these political and economic coalitions to deliver the largest subsidies.

\section{Local Incentives to a Neoliberal Subsidy System}

The International Subsidy System at its core is a result of intermixing state and government interests with that of major corporations. In the need to attract investment, lower unemployment, and raise competitiveness, subsidization has become a central measure to participate in the system. While a Canadian province may have pioneered this particular manner of economic competition, the origin of the system itself returns to the home state of the MPAA. The support in the United States for concentrating industries and strengthening corporations was heavily tied to the growing trade deficit as well as increased competition from growing economies around the world. For a time these newly empowered and transnationalized corporations retained American economic leadership in the neoliberal environment, but after thirty years we have the absurd result today of costly and artificial competitiveness.

As a result, the systemic race-to-the-bottom and the empowerment of leading corporations has a spiraling effect. Existing expectations, such as open markets and low regulation, increases dependence on attracting these 
corporations, which itself generates leverage to expand their profit-making expectations, such as protecting intellectual property rights alongside subsidization. As this dependence on transnational corporations grows, more actors see the necessity of competing in the system rather than restructuring it. In other words, as neoliberal capitalism has both centralized corporate power and opened up labor and regulatory competition in international markets, impacted actors have seen a decline in the means to combat the negative structural effects of capitalism in helping to reproduce their own precarity and disposability. Unions and labor organizations are likely the strongest example of this as many have flipped from criticizing corporate subsidies to supporting them as an attempt to ensure job access. Initially unions were some of the first to challenge the legality of subsidies. Film workers in California, who were the ones to coin to the term runaway production, viewed subsidies in British Columbia as stealing production from Hollywood (Preston, 2013). Labor organizations even tried to use Special 301 provision to categorize subsidies as anti-free trade:

Industry workers have long been opposed to runaway production, considering it a form of outsourcing directly attacking their trades, crafts, jobs, and careers—or, more profoundly, their way of life. Coalitions of industry workers trying to end the negative consequences of runaway productions have had two viable options to consider in combating runaway production: (1) petitioning the United States Trade Representative (USTR) to determine the legality of foreign film incentives; or (2) lobbying for film incentives at the state, local, and federal levels. On September 4, 2007, a 
group called the Film and Television Action Committee (FTAC), a coalition composed of unions, municipalities and individuals whose livelihood and economic security depend on the film and television production industry, filed a petition with the USTR under Section 301 of the Trade Act of 1974. In its petition, FTAC argued that subsidies offered by Canada to lure production and filming of U.S.-produced television shows and motion pictures were "inconsistent with Canada's obligations under the [World Trade Organization] Agreement on Subsidies and Countervailing Measures. McDonald (2011, pp.106).

The protections, laws, and rules that have become important tools for MNCs, including the US Special 301, ultimately failed in protecting union wages, benefits and jobs. The growth of dependence on attracting transnationals has contributed to a system that further entrenches corporate oligarchic power. As coalitions supporting the International Subsidy System have expanded to include labor, consumers and other constituents, most governments and politicians have taken the route of participation in the system. Through this participation there is little chance of reforming the clear contradictions in competing subsidies, as many of these states end up reinforcing the hierarchy and control of the Major Studios.

Even if interest groups or associations disagree, they tend to defer to the more powerful group, which in most cases in film is naturally the MPAA or one or more of its members, giving the MPAA more influence in lobbying governments. 
The EU has played a leading part in driving market logic and pushing for neoliberal policies. Specifically, the early EU adopted American lobbying techniques to develop cohesive corporate-EU representation with the WTO (Schaffer, 2006). With the neoliberalization of the WTO itself, this corporate relationship and lobbying was naturally strengthened around more complex trade relations, much like the North American lobbying system (Young and Peterson, 2006). As corporate-state relationships became closer, and subsidization became required for the industry, the International Subsidy System has become global, as chart Leading Subsidies shows:

\section{Leading International Subsidies ${ }^{52}$}

\begin{tabular}{|l|l|}
\hline Estonia & Up to $30 \%$ cash rebate for film productions. \\
\hline Hungary & $25 \%$ tax incentive on eligible expenses \\
\hline Lithuania & Cash rebate of up to $20 \%$ of the budget \\
\hline Macedonia & $20 \%$ cash rebate on Macedonian production costs \\
\hline Czech Republic & $20 \%$ rebate on qualifying Czech spending; $66 \%$ rebate on \\
& international costs paid to foreign above-the-line cast and \\
\hline Croatia & $20 \%$ rebate on qualifying Croatian expenditure \\
\hline Serbia & $20 \%$ rebate on qualifying Serbian expenditure \\
\hline
\end{tabular}

52 (Buder, 2016) 


\begin{tabular}{|c|c|}
\hline Poland & Only Grants \\
\hline Ireland & $32 \%$ tax credit on local Irish expenditures \\
\hline UK & $25 \%$ cash rebate and up to $80 \%$ tax relief \\
\hline Belgium & $\begin{array}{l}\text { The Belgian Tax Shelter allows the finance of up to } 45 \% \text { of } \\
\text { Belgian-eligible expenses. }\end{array}$ \\
\hline France & $30 \%$ tax rebate on qualifying expenditures in France \\
\hline Malta & $\begin{array}{l}25 \% \text { cash rebate of eligible expenditure with an additional } 2 \% \\
\text { if the production features Malta culturally }\end{array}$ \\
\hline Italy & $25 \%$ tax relief on qualifying expenditures \\
\hline Austria & Cash rebate of $20 \%$ eligible production costs \\
\hline Germany & $\begin{array}{l}\text { In recent years, Germany has significantly slashed its federal } \\
\text { film funding, from } \$ 95 \text { million to the current } \$ 68 \text { million. The } \\
\text { DFFF offers a grant that covers } 20 \% \text { of German production } \\
\text { costs with a maximum grant limit of } \$ 4.5 \text { million (and } \$ 11 \\
\text { million in exceptional cases). Germany also has } 17 \text { regional } \\
\text { film commissions to help with production logistics and funds. }\end{array}$ \\
\hline Iceland & $25 \%$ cash rebate on all eligible expenses \\
\hline Norway & $25 \%$ cash rebate on all eligible expenses \\
\hline
\end{tabular}




\begin{tabular}{|c|c|}
\hline Singapore & $\begin{array}{l}\text { In 2004, the Singapore Tourism Board introduced the "Film in } \\
\text { Singapore Scheme," which promotes production in the } \\
\text { country by subsidizing up to } 50 \% \text { of qualifying expenses } \\
\text { incurred in Singapore, including local talent, production staff, } \\
\text { and production services. Additionally, there are various grants } \\
\text { available through the MDAS, including a "Production } \\
\text { Assistance" grant that supports up to } 40 \% \text { of qualifying } \\
\text { expenses. }\end{array}$ \\
\hline Malaysia & $30 \%$ cash rebate in qualifying local expenditure \\
\hline Fiji & $\begin{array}{l}\text { Film Fiji offers a whopping } 47 \% \text { tax rebate on production } \\
\text { spend in the country. }\end{array}$ \\
\hline Australia & $\begin{array}{l}\text { Producer Offset ( } 40 \% \text { rebate on productions shot in } \\
\text { Australia); PDV Offset ( } 30 \% \text { rebate on post-production work } \\
\text { conducted in Australia, regardless of where the production } \\
\text { was shot) }\end{array}$ \\
\hline New Zealand & $\begin{array}{l}\text { The New Zealand Screen Production Grant offers a } 20 \% \text { cash } \\
\text { rebate to qualifying expenditures; you can also qualify for an } \\
\text { additional } 5 \% \text { uplift if your project meets requirements proving } \\
\text { it will boost the country's economy }\end{array}$ \\
\hline Canada & $\begin{array}{l}\text { Depending on the province, producers can access combined } \\
\text { federal and provincial tax credits ranging from } 32 \% \text { to } 70 \% \text { of }\end{array}$ \\
\hline
\end{tabular}




\begin{tabular}{|c|c|}
\hline & $\begin{array}{l}\text { eligible labor, as well as tax incentives on local qualifying } \\
\text { spend ranging from } 20 \% \text { to } 30 \% \text {. }\end{array}$ \\
\hline Colombia & $\begin{array}{l}\text { Two-tier cash rebate system provides } 40 \% \text { for film services } \\
\text { (including services related to post-production, artistic, and } \\
\text { technical services), and another } 20 \% \text { for film logistical } \\
\text { services (including services provided for transport, } \\
\text { accommodation, and food) }\end{array}$ \\
\hline Trinidad \& Tobago & $\begin{array}{l}\text { Cash rebates up to } 55 \% \text { for expenditures on qualifying local } \\
\text { labor and } 35 \% \text { on other local expenditures }\end{array}$ \\
\hline Puerto Rico & $\begin{array}{l}40 \% \text { production tax credit on all payments to Puerto Rico } \\
\text { resident companies and individuals }\end{array}$ \\
\hline $\begin{array}{l}\text { Dominican } \\
\text { Republic }\end{array}$ & $\begin{array}{l}25 \% \text { transferable tax credit on all eligible expenditures } \\
\text { including pre-production, production, and post-production }\end{array}$ \\
\hline Panama & $15 \%$ cash rebate \\
\hline Abu Dhabi & $30 \%$ cash rebate on production spend; no sales tax \\
\hline South Africa & $20 \%$ tax credit (production), $25 \%$ tax credit (post-production) \\
\hline
\end{tabular}

While Subsidy programs were clearly designed with local incentives in mind, the contradictions that come out of a competitive subsidization process are apparent in the growth of the power and privilege of a Mass Media Conglomerate. The chart above lists only the highest offers of film production 
subsidies around the world, and therefore does not cover the entire scope of the subsidization system. For the Major Studios of the MPAA, the international subsidy system is both an effect and reinforcement of the global film oligopoly. With an international system of rules against classical protectionism, states have naturally moved into supporting the supply-side of production incentives, which is encouraged by rules codified within the WTO and within regional trade agreements. While one may expect subsidies to be the next anti-free trade topic for the WTO and trade agreements, that they reinforce the corporate power that participated in their development makes that unlikely.

Rather, the Mass Media Conglomerate is focused on using international trade negotiations to promote a continuous expansion of Intellectual Property Rights and Copyright protection. Unless the system is greatly restructured, states will continue to choose between subsidizing leading industries, or seeing them flee, especially for those industries that are most mobile. For the Major studios, who receive the bulk of subsidies, are the most globally mobile, and have international access to partnerships and distribution, this system helps reinforce both their economic and political leverage, but also allows them to build a larger coalition of labor and smaller studios who in turn expand their systemic influence. 


\section{The New Media Oligopoly}

In this final chapter I will start by examining the current situation of the Major Studios, as well as their likely trajectory in the near future. In this, we will see further concentration (primarily in Disney), acquisitions of the intermediate Majors, and the decline of Paramount/Viacom due to not engaging with the modern market. I will then analyze how this has affected the MPAA and the larger industry of media. Both due to new technology and greater monopolization, major competitors in film and media have only come from capital-rich, massive corporations, all of which have near monopolies in semi-related sectors or industries. From here I will examine the current political strategy of the MPAA. With the admission of Netflix to the association, an acceptance of digital streaming as a primary distribution sector, and the continued focus on international markets, the MPAA has developed and participated with a network of nominally domestic associations in key countries to set international norms related to film, such as copyright and its enforcement. Finally, I will examine solutions to limit both the corporate power and the state relationship and reliance on leading businesses, which will necessarily go beyond reinforcing antitrust legislation. 
28. Domestic Box Office Share by Major Studio

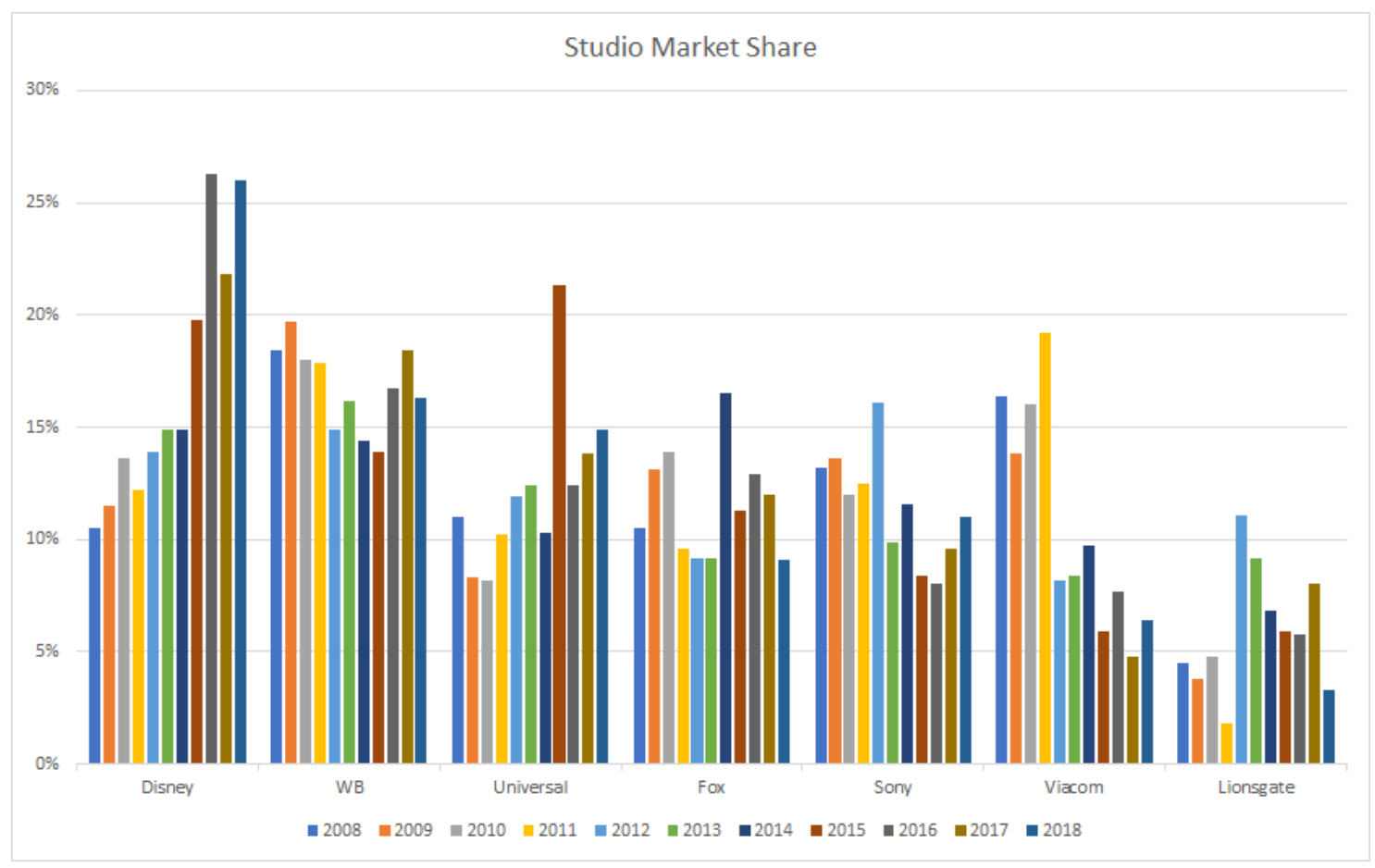

\section{Disney and Fox}

\section{Box Office Share by Year (Boxofficemojo)}

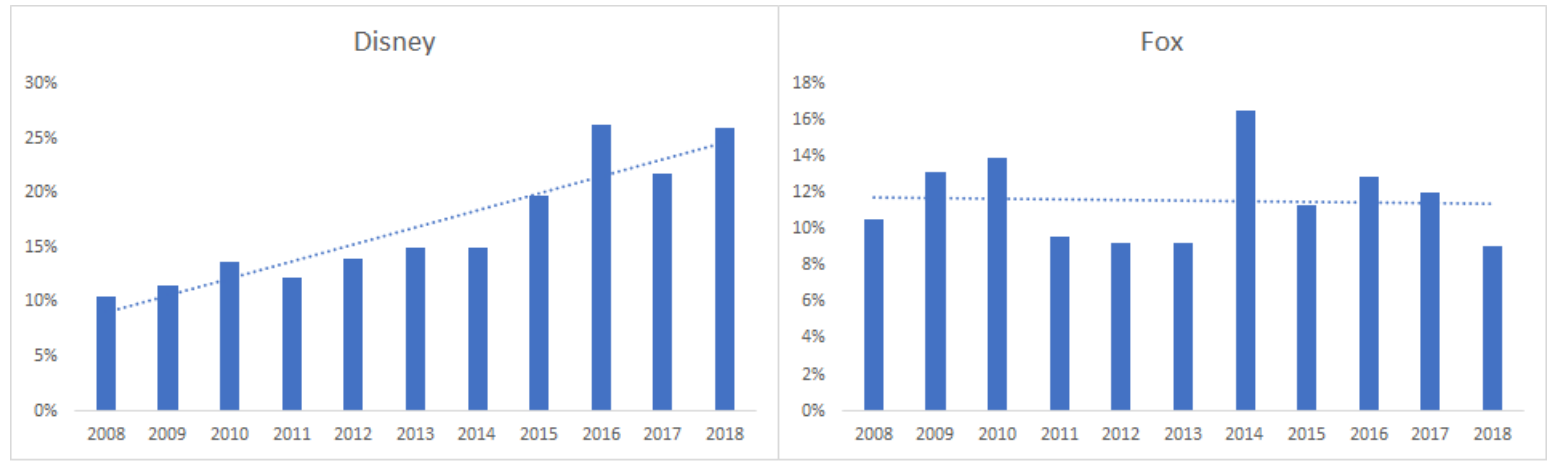

As can be seen from the chart above, Disney has been a clear winner at the box office in recent years. As the largest Studio and the closest to a traditional Mass Media 
Conglomerate, Disney has double-downed on acquisition of studios and IP in recent years with Pixar, Marvel, and LucasFilm, which could have been seen as near minimajors if not for their selective genre focuses. However, the largest change in the MPAA and oligopoly is due to Disney's acquisition of a Major Studio: 21st Century Fox. Fox was one of the participants with Hulu and had sustained a strong, if stagnant, market share at the Box office. The spin-off of its television and news channels to sell the filmed entertainment portion to Disney shows the decline in synergy between film and traditional broadcast (including cable and satellite) in the near future. Disney itself has been focusing more on streaming and subscriptions with the launch of Disney+, which releases its family-oriented, Disney-branded media. More importantly to the oligopoly, however, has been the acquisition of Hulu via Fox. As one of the founders of the streaming platform (along with Fox and NBC Universal) Disney had acquired a majority share with the acquisition of Fox and is in the process of purchasing the remaining shares to use Hulu to release non-family oriented media.

With the purchase of Fox, Hulu, and the development of Disney+, the company is poised to be one of the leading streaming companies along with its leadership at the box office. This leaves Disney as the most traditionally structured Mass Media Conglomerate, but also reveals the tendency toward monopolization, especially as other monopolized sectors enter into the market, both from new entrants such as Amazon and Netflix, but also purchasers of leading competitors Warner Bros. (AT\&T) and NBC Universal (Comcast). Thus, while the Disney purchases look like a monopolization within the media oligopoly, it is also a necessary response to a market of media-technology, as major tech firms attempt to synergize and "wall-in" their own platforms and products. Again, Disney has done this most traditionally as far as Mass Media Conglomerates go, by studio purchases and controlling distribution/exhibition. The remaining MPAA 
members have looked to other means of competition, or have seen their decline in recent years.

\section{Warner and Universal}

\section{Box Office Share by Year (Boxofficemojo)}
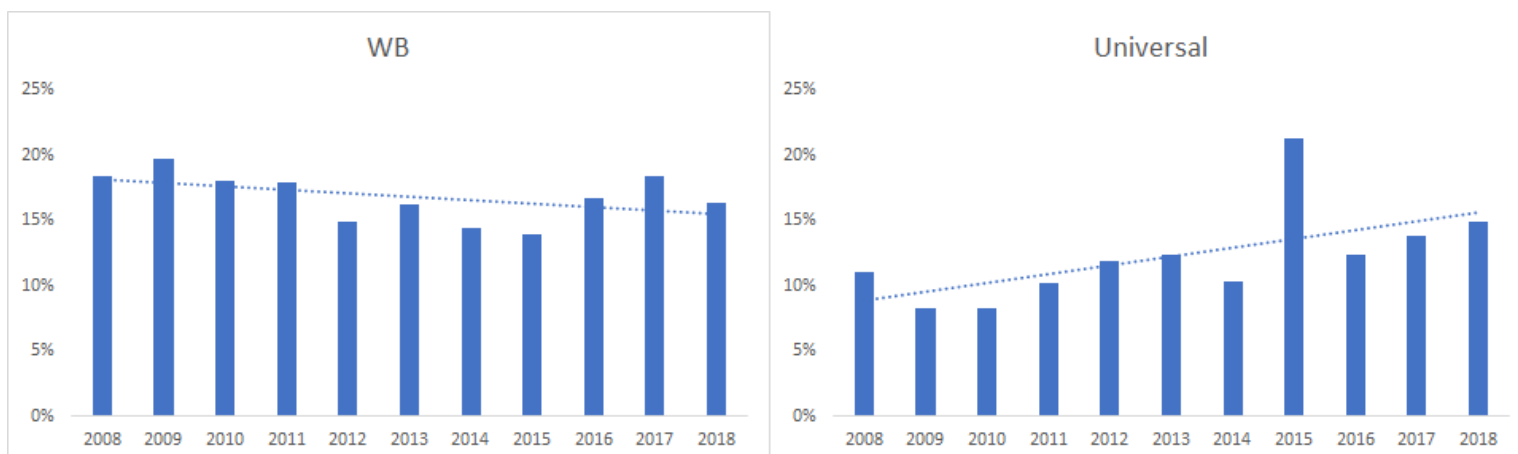

While Warner Bros. may have seen a decline in market share over the past 10 years, it started from an exceptionally high-level position. In past years, the studio has released some of the most profitable franchises, Harry Potter, as well as Lord of the Rings, and its own super heroes in Batman and Superman. However, more recently the studio has struggled, especially in competing against Disney's successful Marvel films, with its less successful comic book IP. On top of this, Warner is especially active in working on co-productions with smaller, foreign studios, which is becoming increasingly utilized for internationally produced and distributed films. Likewise, Universal does not have the strongest IP lineup. Compared to Disney's focus on younger children, Universal has focused mostly on the profitable PG to PG-13 range, with leading IP being Fast and the Furious. While Universal has some of the strongest historic IP franchises, in modern times it has quite few as well. Despicable Me and the Bourne series are the most profitable, and it has successfully revamped Jurassic Park, but, like Warner, Universal Pictures has faced difficulty in generating its own film franchise comparable to Disney's 
acquisitions. The attempt to revive the oldest film franchise, Universal's classic monsters, has largely resulted in failure with numerous "first attempts' ' with The Wolfman, Dracula Untold, and The Mummy all being lukewarm at the Box Office. However, what makes these studios especially notable is their acquisition by telecommunications companies. Comcast's purchase of NBC Universal occurred in 2009, with AT\&T following in more recent years with the purchase of Time Warner in one of the largest media acquisitions in history. Most notable, however, is why communication companies view media producers and studios as synergetic to their core industry. Unlike Disney, integrating existing studios into its media distribution system, these companies do not directly own distribution or streaming services, on which their studios can release exclusively. Rather, the connection between Internet Service Providers and media producers is the relatively new importance of media streaming and Videos On Demand (VOD), which provides new sector monopolization via platforms and exclusive content. Already a very monopolized industry on its own, ISP and telecoms could provide more opportunity, not only for product synergy, but for exploiting platforms and narrowing consumption options. This was likely an interest in combining internet access with subscription media platforms with the decline of Net Neutrality. While the lack of enforcement of Net Neutrality has not reached the worst fears of critiques, who saw a balkanization of not only subscription platforms, but the internet as a whole, there has been some growing tendencies of ISP corporations attaching telecom services with media subscriptions. This has ranged from basic media subscriptions with internet or phone services to utilizing "zero-rating" systems, whereby only certain content will not count against data caps, which is especially important for smart phone service and an important expansion with AT\&T's entry to the industry. 


\section{Declining studios}

\section{Box Office Share by Year (Boxofficemojo)}

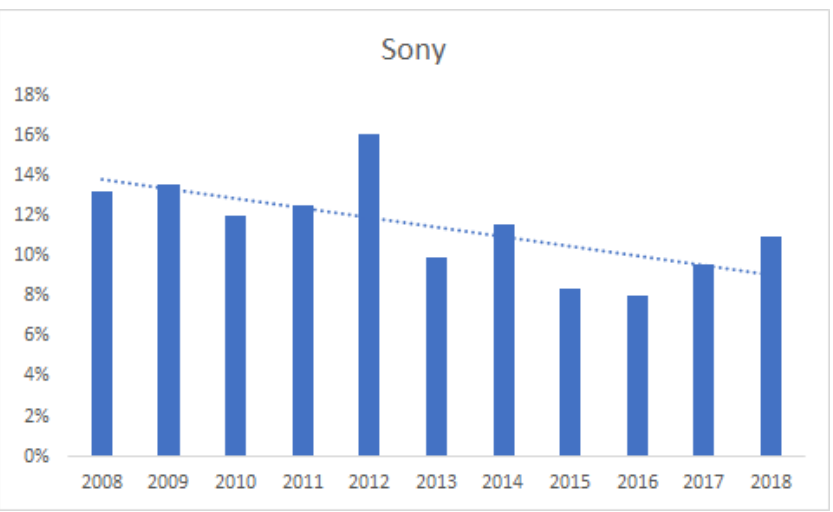

While Sony's Columbia has overall higher market shares in recent years, like Paramount it has experienced some market decline over a longer period. This is partly due to relatively weaker film franchises, compared to the more successful majors, but is also partly due to the structure of the company. Compared to other Mass Media Conglomerates, the synergy between the main branch of the company and film and media is not as direct. Sony was originally positioning itself to connect VHS technology to content producers, which was reshaping the industry at the time of Sony's purchase of Columbia. While this may have had some importance in later optical technologies, such as DVDs, the synergy was never as strong as what we see with today's tech companies, who already own massive servers and digital distribution. In fact, Matsushita (now Panasonic) followed Sony's lead into film and purchased Universal's parent company, MCA, in 1990, but only kept it five years before selling it off. Rumors of Sony selling off Columbia have been common in recent years.

Where there has been some success in developing a streaming platform to compete with Hulu, Netflix, and now Disney+ was in Sony's hardware background with the latter iterations of the Playstation systems. The newer generations of the system, along with other consoles, such as Microsoft Xbox and Nintendo Wii, have attempted to 
become general living room consoles for all media, with streaming and purchasing services, much like how Apple limits its products to its Apple Store. However, this has numerous competitors even outside the video game market, including Amazon Fire TV, Google Chromecast, Apple TV, Roku (spun off from Netflix), all of which offer access to streaming services via television. While Columbia still has strong market share, despite a decline, and Sony continues to be a global conglomerate, the company remains relatively weak due to lack of franchises and lack of cooperation with other Majors.

\section{Box Office Share by Year (Boxofficemojo)}

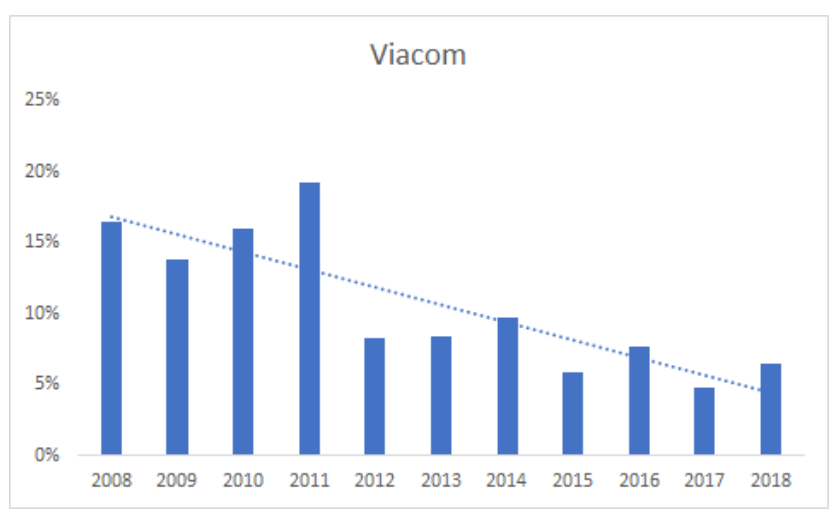

Of the Majors, Paramount and parent company Viacom have been struggling the most. Their market share has significantly been declining, with several years being below Lionsgate, which is usually considered a mini-major and not a member of the MPAA. Much of this is due to the stagnant focus on existing television networks and lagging behind to online distribution. Many place the blame on aging founder Sumner Redstone, who still has majority control of the business. Although separated from CBS, Redstone has avoided moving exclusive content online and away from their television distribution networks, which, in the past, was an essential distribution stream and revenue generator. As a result, Viacom had not joined Hulu, and while CBS (also controlled by Redstone, though technically a distinct company) released its own 
streaming in 2014, there was little interest. Finally, CBS All Access received a bump in subscribers by releasing the Star Trek Discovery series, a Viacom IP, exclusively on their platform. This pushed the subscribers to 2 million, far lower than subscribers for Hulu and Netflix, and likely just for Star Trek as there is little other exclusive content.

\section{Box Office Share by Year (Boxofficemojo)}

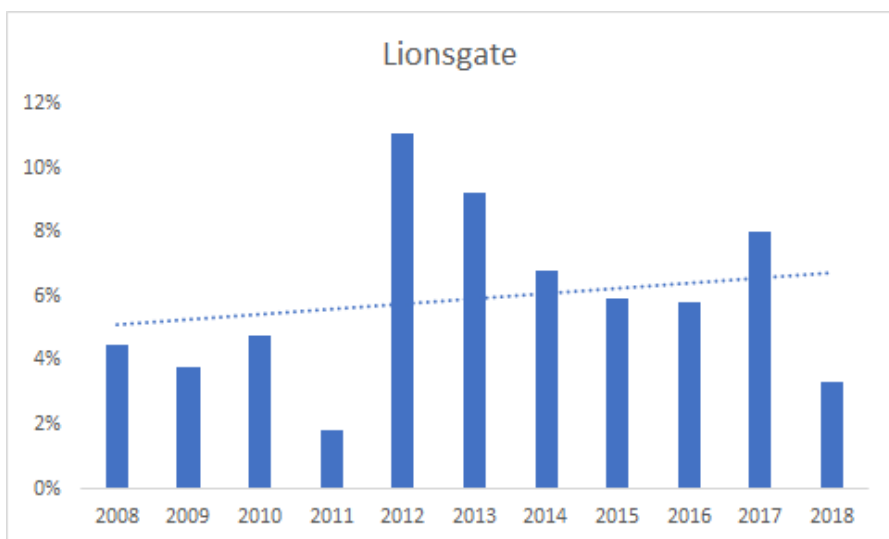

As Fox studios joins Disney, and two of the members see decline, Lionsgate has increased its position to having essentially become the sole domestic mini-major. It qualifies as a mini-major due to having a substantial market share, but without having the resources and distribution networks of the Majors. Lionsgate was able to reach a comparable market share by adhering to the major strategy of buying out growing competition. In 2012 Lionsgate purchased Summit Entertainment, which itself was receiving the highest revenue in the domestic market with rising franchises such as The Twilight series and later The Hunger Games. In exhibition, Lionsgate did co-own the film cable channel Epix, along with Viacom and MGM, but later sold its share. Lionsgate still owns Starz. Inc, a network of cable channels, but still lags far behind the extensive networks the Majors own. As it stands, Lionsgate is the sole remaining mini-major, with global releases despite a lack of distribution ownership. 


\section{Changes to Industry Competition}

The MPPA and Major Studios are currently in a period of reform to deal with a changing technological landscape that is bringing more overlap with other actors and industries. Streaming services have heightened competition, not only in parallel service in Netflix (the most recent addition to the MPAA), but also with tech giants such as Google (Youtube) and Amazon, who easily match the financial prowess of the Majors. This technological disruption to the oligopoly has many similar qualities that predicated industry liberalization in the 1980s. At the time, new media corporations and non-media tech firms were overlapping with film through cable and VHS. The solution was liberalization and greater concentration around distribution and exhibition. The same strategy is now appearing, but on a much greater scale. The largest of the studios are merging into larger Mass Media Conglomerates, with two being incorporated into leading telecommunication corporations, Comcast and AT\&T. The recent addition of Netflix to the MPAA means the association is larger, but potentially means the threshold to be a Major Studio has increased to include larger technology conglomerates.

Although filmed entertainment had long been subject to a long stream of product iterations, from toys to video games and theme parks, Video on Demand (VoD) and Streaming services have been among the largest disruptions in the film industry. In many ways, the digital exhibition of film has replicated many of the fears VHS caused for the Majors: studios fear ease of piracy, dispersion of product control, and increased substitution of entertainment products. More so than even VHS, streaming has even reshaped how production and releases are done, even affecting other exhibition sectors. This has affected the film style as cinematography designed for the big screen may not translate to home systems, or, more drastic yet, computers and smartphones. These 
style and distribution changes have increased further as dedicated streaming services, such as Netflix, have started their own productions of both TV shows and feature-length films. It is the latter point that is driving most change in the MPAA.

\section{Hulu and Netflix}

While the growth of Disney and movement of other Studios into telecommunications presents its own complex effects on the market, one of the clearest examples of collusion between the Studios was Hulu. Founded as Netflix was moving to digital streaming, Hulu comprised the most successful of the Major Studios: Fox, Disney, Universal, and later joined by Warner. These four Majors have brought Hulu to be the 3rd largest platform after Amazon and Netflix. Hulu has been able to bypass what should be seen as clear collusion of a cartel, based on the expectation that Hulu will still have to bid competitively for content against Netflix and Amazon. Hulu, however, has been losing money, despite the fact that these four Majors are pouring in money, and much of their content, which was on Netflix, has been moving exclusively to Hulu. This means, as much of the leading content is from the majors, the costly investments from Hulu to compete with other streaming services, come from and goes to the Major Studios (Spangler). This has been pushing Netflix to produce originals and get other exclusives, thus becoming a Major producer itself.

The multiple and complex network of sectors, tie-ins, and platforms can appear to give credence to the argument that deregulation of such industries was not only necessary, but that the complexity would make any attempt at antitrust regulation overly difficult, if not impossible. However, the solution in allowing the Majors to compete via Hulu was based on a contrived structure, which has been a common issue with associationalist solutions. Allowing some degree of consolidation, collusion, or outright 
monopoly has consistently been used to solve larger, structural problems. In some ways these have been used to avoid the more difficult systemic and structural changes and adjustments, but the larger issue is that these short-term solutions have been utilized by those in power to increase these contradictions. As such, Hulu may be clear collusion among these four studios, but the novelty of streaming had allowed Netflix itself to be a clear monopoly not even 10 years ago; vice versa, allowing monopolistic Netflix to produce its own content, something that would not have been allowed under the Paramount Decree or Fin-Syn, had become necessary not only due to content from the majors being hoarded by their own platforms, but also because earlier industry liberalizations had already allowed exhibitors to produce content.

As such, while it was clear that Netflix needed competition so as to not eventually abuse its monopoly, the industry necessarily turns to other quasi-monopolies, or cartel via Hulu, as the only means to counter the perceived monopoly of Netflix. This conforms to the standard assumption of oligopolistic competition, but it ignores the monopolistic ties each leader has within other sectors. Netflix itself is the least inter-sectional, and thus the most vulnerable. Its continued success depends largely on the incumbent power of having been a streaming service monopoly for a short period. In addition to the challenges posed by Netflix, one should expect more competition and changes for the Majors as a result of competition from other monopolizers in complementary industries (again, Amazon and potentially Google and Apple). As such, these challenges from emerging exhibition platforms is what is likely driving the new round of conglomeration-into telecom and Internet industries. As a result, the willingness to participate in the Hulu cartel is indicative of successful adjustment to increase collusion, sector synergy and control, and taking advantage of monopolization. In this, the four Hulu partners had been 
able to grow their market share, while Sony and Viacom have been facing more difficulty in their weaker adoption to this new sector.

Instead of creating competition, the encroaching competition coming from other sector monopolies leads to more concentration. It is monopolization to deal with competition. A primary issue is that existing loose antitrust enforcement leads to what should be seen as unfair practices: an incumbent monopoly once the technology is established, and two tech giants (Google's Youtube and Amazon) that can leverage other sectors--ecommerce and a host of computing services and systems (google search, google operating system, google chrome, etc.). The fusion of the power of Mass Media Conglomerates with the power of conglomerates that dominate online platforms has provided opportunities for further consolidation in an attempt to synergize the control and delivery of content. That the power of already existing monopolies expands within this system is an inevitable byproduct of weak to non-existent antitrust laws in an era of neoliberalism. Antitrust regulators will approve merger after merger as long as there is no clear evidence that consumer prices will be dramatically affected. This leads to further consolidation across platforms as Mass Media Conglomerates and powerful digital corporations use their corporate power to compete with other oligopolies for the highest value acquisitions.

\section{New Competitors}

The new exhibition sector of digital streaming, being led by technology giants, is rightfully being treated by the Majors as a major threat to their dominance. However, what should be more competition in filmed entertainment is counterintuitively what is driving greater concentration in the broader communications Industry. In part this is because an international media firm can benefit greatly from a centralized streaming 
platform, especially for regions missing distribution branches, but also the financial cost of mergers and acquisitions can be offset by stable and larger market shares. It is thanks to the existing normalization of monopolies, as well as their need for international "competitiveness," that concentration has been seen as an answer to economic changes and uncertainty, rather than more market competition. It is thus important to emphasize that even should these subsequent mergers not have occurred, the growth of competition in digital media was still constituted by what are largely monopolies in their core industries: Google, Amazon, and for a time Netflix. Thus, even as some members may leave or others join the MPAA, some manner of oligopoly tends to remain--now as even larger conglomerates.

The clearest parallel with current consolidation is the comparison between Netflix and HBO in the 1980s. With the addition of cable and home video to existing exhibition of theaters and broadcast, it is common to suggest that the complexity and widening of the market is what helped lead to deregulation of antitrust, opposed to their enforcement against HBO (Prince, 2008). Rather, the rise of HBO, and the monopoly it initially held on cable, allowing for, as the studios felt, unfair power in price negotiations for film, was one of the driving reasons for the Majors and the MPAA to push for antitrust deregulation. The cable exhibition sector that disrupted the Studio relationship with theater releases was "fixed" by the oligopoly integrating all exhibition into Mass Media Conglomerates. Today's competition of digital streaming and entries of tech giants, with monopolies of their own, is likewise being fixed through integration into Media-Tech Conglomerates.

The success of Netflix also largely replicates HBO's early success as being the first major supplier of a new technological service. Starting as a mail-order DVD subscription service, Netflix included a streaming option as internet speeds and 
bandwidth costs improved. Already popular with its DVD service, Netflix was the sole major streaming service with the exception of Hulu, which took time to popularize. Founded in collaboration with three of the six Major Studios, Hulu was not only an alternative streaming service, but allowed the Majors to deal with Netflix collectively. As a result, content from the Majors that had initially been on Netflix was being pulled for exclusivity as the contacts expired. Because of this associationalism to counter Netflix, Netflix had to move into producing and funding its own original content. Due to its strong incumbency of subscribers and growth of exclusive production, Netflix has increasingly taken the shape of a Major studio, focused on monopolizing distribution and exhibition and financing exclusive production.

By contrast, Amazon and Google entered the streaming sector from their own monopolized industries. Google's Youtube is clearly the most distinct, primarily composed of independent and amateur videos. In recent years, however, it has pushed for professionalization by creating a threshold of subscribers and views to monetize content, supporting the development of Youtube networks, adding the option to rent theatrical films, and developing a subscription service with its own exclusive content called Youtube Premium. While still the most distinct streaming service based on content, Youtube by far has the largest user base. On top of that, the threat from Youtube and Google comes heavily from the potential to leverage their existing monopolized sectors into their streaming service. Google has a variety of potential influences from Android to Chrome, but the offer of Youtube Premium itself is based in part on original and produced content, but also on removing ads on all Youtube amateur and independent videos.

Amazon has taken a similar, if not harsher step, with Amazon Video and the subscription service, Amazon Prime. Tying in their core sector of ecommerce and 
shipping, along with multiple other sectors and products the company has since entered, the inclusion of video streaming through Prime leverages Amazon's platform much farther than the streaming services of Youtube and Netflix. Being a technology conglomerate and online store, Amazon has a lot of synergy to enter the streaming market, especially as it already maintains a massive amount of servers for its other services. However, the use of a corporate-wide subscription service, much in the same vein as Google user services and the "walled gardens" of Apple's operating systems, drives competition not solely based on quality of service or price, but based on number of tie-ins and how monopolized they are for best leverage. On the one hand, this unfair, or at least unreplicable, practice requires a comparable response to maintain competitiveness as Disney, At\&T's Warner Bros., and Comcast's Universal have done. On the other side, the barrier to entry generated due to the concentration of the oligopoly makes the most likely entrants those who can leverage a corporation roughly equal to the size of the MPAA members themselves. This is especially true when looking at the initial response of the Major Studios to Netflix with the creation of Hulu.

\section{Video On Demand Users By Platform:}

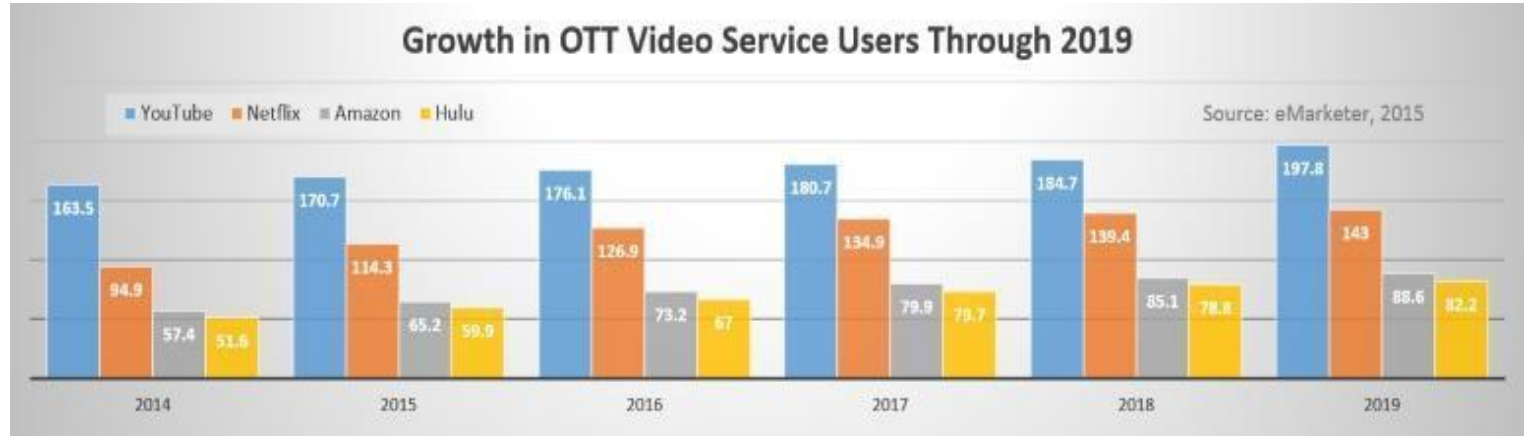


35. Spending on Production and Acquisition of New Content:

\section{Shopping Spree}

Content acquisition spending

$\$ 3.0$ billion

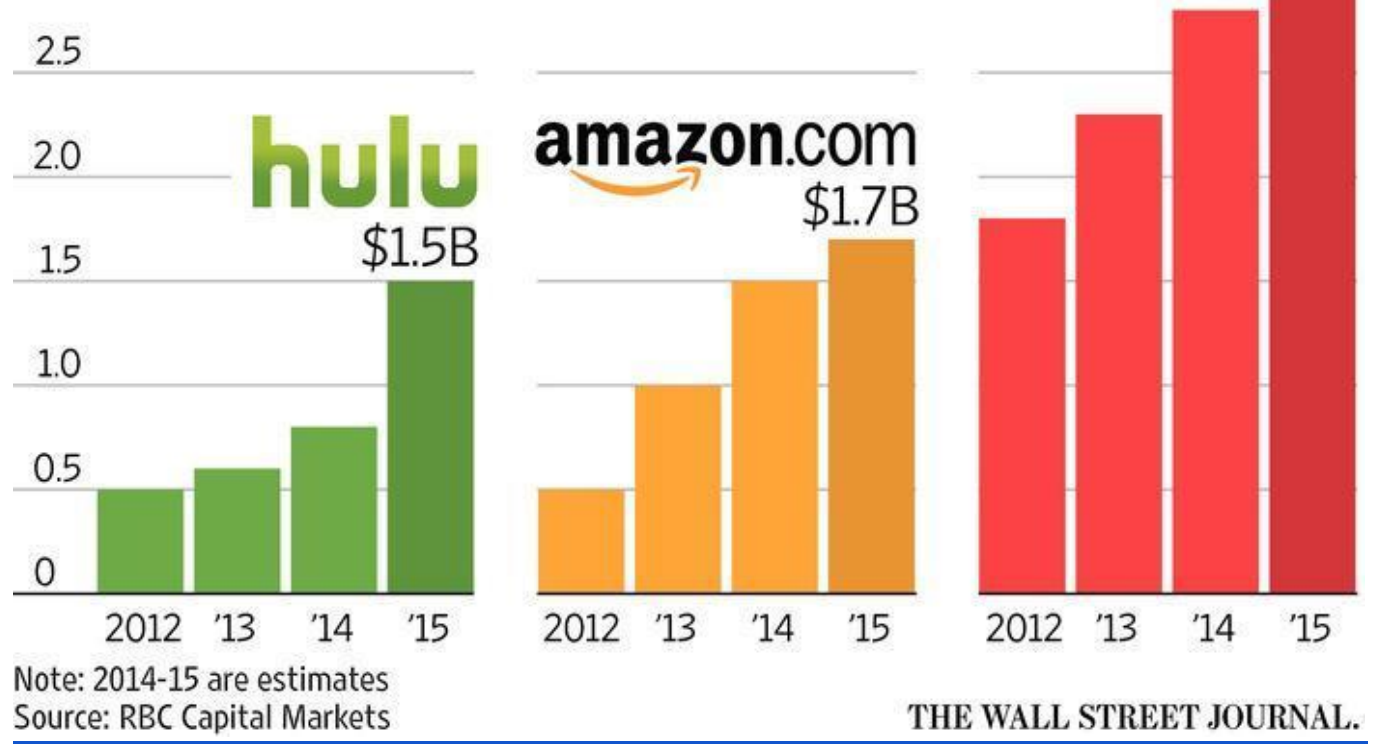

\section{Changes to Cooperation}

How the MPAA membership itself is reshaping is illustrative of how the media oligopoly will look in the near future. Netflix had been a long-time adversary of the Studios, but has been accepted as a member of the MPAA in 2019. At the same time the most successful of the Majors have been consolidating and merging with telecommunications. The addition of the digital streaming service, along with the intermixing with other tech industries, implies the Mass Media Conglomerates will be integrating new sectors of competition and entrenchment, likely ending as a form of 
Tech-Media Conglomerate. By contrast, the Studios that have failed to adapt to this new consolidation and associations have been seeing a decline in their market share. However, this turns out, what this makes clear is that the trajectory of consolidation is not slowing down as the Oligopoly may become both more consolidated in membership, while also becoming larger and more interconnected associations.

This move will clearly make it harder to correct any anti-competitive practices, such as market shares or sector monopolies, while also increasing the tendencies toward justifying monopolies as "necessary" to compete in an even more consolidated marketplace. As such, labor interest, local industry, national culture, and even the blatant corporate payoffs in subsidies, will become more and more entrenched into the international system. Copyright and Net Neutrality issues will be increasingly likely to reflect the corporate position, especially as telecoms becomes intertwined with production and exhibition. On top of this, any deepening of the oligopoly will correspond with a widening, especially as the untapped markets are also the quickest growing. While much of Asia still offers room for the oligopoly, China is by far the largest and most important. China is also one of the last adversarial governments to protect its market from the Major studios, which will likely exacerbate conflicts within the international market, international law, and even directly into international relations.

As international markets both provide more than half of the Majors' revenue and have the largest room for growth, much of the MPAA's activity has been in developing an international system of associations to influence individual governments and set a global norm. This was done by partnering with local film interests (many of which have production relations with the Major Studios) to create national film associations in over 35 countries (see "FACT" Anti-piracy Network List, below). Much like the MPAA in America, these trade associations lobby their respective governments for the interest of 
their members, usually over copyright and its enforcement. What is unique, however, is that these organizations comprise domestic film studios and the MPAA, commonly with the Majors being the leading or majority of members.

From this growth of corporate influence, overlapping associations, and broadening of social and political influences, comes four important revelations: 1) the development and growing importance of Intellectual Property is a means to create scarcity out of knowledge, which is naturally abundant. This is the foundational goal of the organizations in question, especially as most are developed around combating piracy, especially online. 2) Setting an international legal norm to retain dominated markets while positioning their entry into growing markets--in particular China. 3) Strengthening not only ties with politicians and other state apparatuses, but generating a partnership of shared interest to drive multiple states to defend the international norm globally. 4) And control of an internationally dispersed industry. As examined in previous chapters, with the expansion of exhibition, new distribution markets, growth of producers, and greater connectivity with other industries, the flexible monopolization within neoliberalism needs a new means of centralization. As a result, more than valueadded or a means to combat piracy, the strengthening of Intellectual Property will filter control by compounding the power of those corporate actors who lead in finance, exhibition, and cultural dominance.

\section{6. "FACT" Anti-Piracy Network}

- $\quad$ FACT (UK):

- AFACT (Australia)

- NZFACT (New Zealand)

- INFACT ("Irish National")

- CYFACT (Cyprus):

- IFACT (Hong Kong)

- TFACT (Taiwan)

- MFACT (Malaysia)

- SAFACT (South Africa):

- MOTION PICTURE ASSOCIATION - CANADA

- NY FEDERATION AGAINST COPYRIGHT THEFT

- Copyright Collective of Canada 
- Verein Fur Antipiraterie der Film-und Videobrache

- Federazione Anti-Pirateria Audiovisiva (Italy)

- Federacion Para La Proteccion De La Propiedad Intelectual (Spain)

- Assoc Mexicana de Cine y Musica AC (Mexico)

- Russian Anti-Piracy Organization (Russia)

- Foundation of Audiovisual Works Protecti (Poland)

- Society for Protection of Copyright Inf (Germany)

- Korea Content \& Technology Alliance (Korea)

- MOTION PICTURE ASOCIATION AMERICA LATINA (Brazil) (N/A Controlling Entity)

- Schweizerische Vereinigung zur Bekämpfung der Piraterie (SAFE) (Switzerland)

- Belgian Anti-piracy Federation (Belgium)

- Association for the Protection of Movies and Music (Brazil)

- Motion Picture Association - China (MPA-China)

- Danish Anti-Piracy Group (AntiPiratGruppen) (Denmark)

- Association for the Fight Against Audiovisual Piracyv(Association de Lutte Contre la Piraterie Audiovisuelle - ALPA) (France)

- Society for the Prosecution of Copyright Infringement (Gesellschaft zur Verfolgung von Urheberrechtsverletzungen - GVU) (Germany)

- Motion Picture Distributors Association (India) Pvt. Ltd. (MPDA) (India)

- Japan \& International Motion Picture Copyright Association (JIMCA) (Japan)

- Foundation for the Protection of Copyright for the Entertainment Industry Bescherming Rechten Entertainment Industrie Nederland (BREIN) (Netherlands)

- Motion Picture Association - International (MPA-I) (Singapore)

- Swedish Antipiracy Bureau (Svenka Antipiratbyrån -APB) (Sweden)

- Motion Picture Association - Thailand

- Ukrainian Anti-Piracy Organization (Ukraine)

This network of associations had its origin with the British "Federation Against Copyright Theft" (FACT)-- the original and better known of the FACT organizations. This British FACT organization was founded in 1983, at a time that the MPAA and Major Studios were still in the process of regaining their position and international access. By contrast, many of the later FACT and MPAA associations were developed at the modern peak of the Majors. At the foundation of FACT, Britain was already uniquely integrated to Hollywood's international production and distribution. As such, this original FACT was able to operate as a stepping stone to a secured market into the rest of Europe. It is thus organizations such as FACT that helped set and export neoliberal norms to foreign markets which are then used as legal expectations for new markets. Once formed as a norm, it is easier to expand these rules and laws as a precedent to more stubborn countries where the film cartel does not yet have a strong foothold. As this had only 
increased in time and expanded under neoliberalism, it is no surprise that it has such associations have proliferated under groups like the MPAA.

In most countries where the MPAA is active, this enforcement is done through a variety of means such as political lobbying, lawsuits, having agents work alongside police and going beyond the legal structure by partnering with Internet Service Providers (ISP) monopolies to combat piracy directly. To avoid public backlash, such activities are imported as a norm in places they are already in place, such as the UK. The MPAA also hides its participation by attempting to appear "domestic" through groups like FACT, which means including at least one domestic studio as cover. The Australian version of the association, AFACT, is the worst offender in this regard with members being the MPAA and only one Australian Studio. FACT, the original, was composed of the MPAA members and several domestic media firms (See Fact Members as of 2015), likely due to the more difficult position of generating legal norms, rather than importing them. Nonetheless, while this had the advantage of legitimacy (especially for future FACT operations) and attaining powerful domestic allies in the industry, FACT was still created at the behest of the MPAA, which supplied half of the FACT budget (Russon, May 24, 2016). It is thus these two English market organizations, FACT and AFACT, that lead and normalize a broader network of anti-piracy trade organizations (McDonald, 2015, pp.83), and have as a result been the most visible and public of the network. 


\section{FACT Members as of 2015}

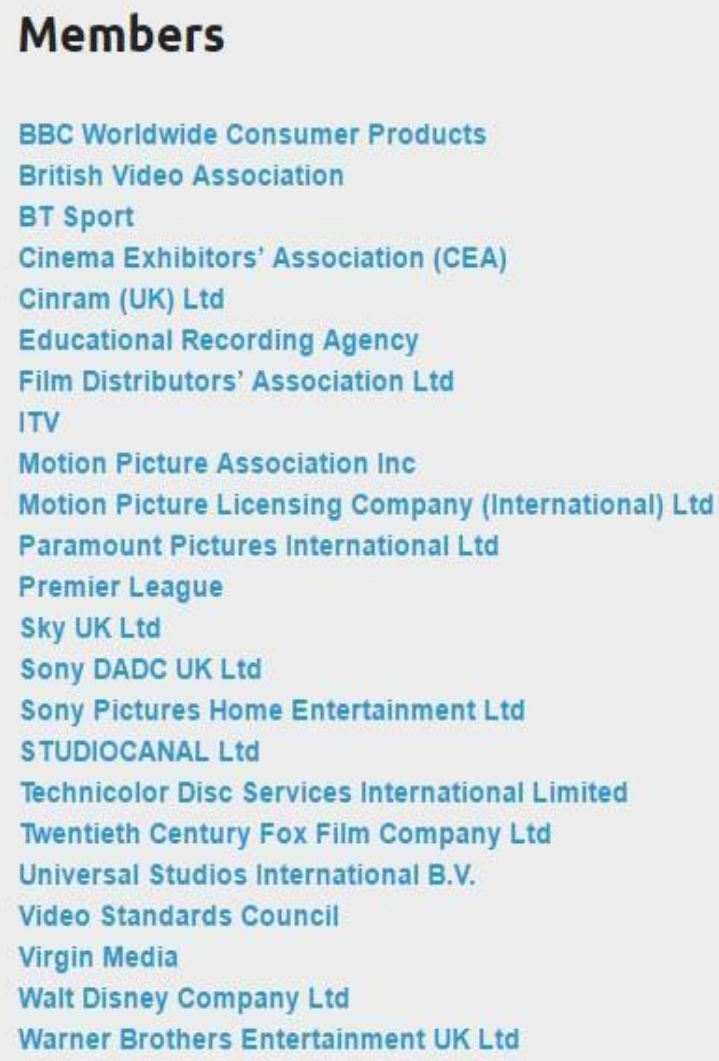

Perhaps the most publicly notorious examples of the MPAA and FACT actions (and impetus for website censorship and the eventual "graduated response system") has been their participation in not only monitoring IP offenders via hefty lawsuits, but also the participation with police operations. FACT officers have reportedly been able to not only participate in interrogation of those arrested who are suspected of recording films in the theater, but apparently lead the interrogation with police there to arrest, confiscate electronic equipment, and officiate the interrogation (Andy, 2013). As one suspect put it:

"I was detained for $3 \mathrm{hrs} 12$ minutes, out of that I was questioned for approximately 40 minutes. One police officer and two FACT officers conducted 
the interview. The police officer sat back and let FACT do all the questioning, so FACT were running the show," the man reports. (Andy, 2013).

These FACT officers are "expected to liaise with law enforcement, they will also be expected to take part in briefings, seizure of evidence and prosecution support" (Andy, 2013). The FACT officers themselves, operating much like and with police, have even been known to show up at suspected infringers' homes for questioning.

This cooperation and partnership with police had developed over time into this quasi-police organization from the private group. As in other states where the MPAA has political influence, these tacit relations have eventually become officiated with new bureaucracies and issues around which they participate. One example of this is the interlacing of police and FACT development into the creation of Police Intellectual Property Crime Unit (PIPCU) in London, which was developed in partnership with numerous other private trade associations, such as BPI (British Phonographic Industry) and IFPI (International Federation of the Phonographic Industry) (both of which have MPAA members), as well as another trade association conglomerates--the Alliance for Intellectual Property, of which the MPAA is a member. The PIPCU, in the enforcement of intellectual property participates in seizing or suspending websites and arresting operators. Targeted sites are referred to the new police organization by "entertainment industry groups," including FACT and BPI (Ernesto, 2014). BPI and MPAA are also the most common actors for blocking of website requests in the UK for servers outside of PIPCU reach. Additionally, there have been numerous complaints that PIPCU site blocking has been done without due process, revealing both the importance laid at copyright protection by the state, as well as the numerous levels of state involvement for the international system (lbid.). 
While this corporate-state enforcement and policing are not necessarily unique or novel, the embedded nature, creation of new policing bodies, and leadership by the private sector MNCs helps to contribute to a new development in what Adrian Johns calls "Intellectual Property Defense Industry" (Johns, 2009). This is the use of new technology and devices to protect the increasingly important status of intellectual property. The Intellectual Property Defense Industry utilizes existing military and policing techniques as well as “...ex-officers, surveillance techniques, [and] encryption-to form a distinct enterprise with branches in digital, pharmaceutical, agricultural, and other domains" including copyright (Johns 2009, pp.499). For the FACT network of International Trade Associations, and increasing move from the private IP defense industry to the public-private IP defense alliance, this represents but one movement toward political dominance beyond the market (market share) and neoliberalism (state subsidization) dominance. This control, integration, and then norm development is part and parcel of the wider international issue related to not only an international oligopoly, but in the question of enforcement against consumers and citizens. Aggressive methods in both monitoring and punishing piracy have thus become an international norm, sometimes in dealing with current or potential customers, such as the absurd event of police raiding the home of and seizing the Winnie the Pooh laptop of a 9 year-old over the downloading of a pop album (Etherington, 2012). This was done at the behest of Copyright Information and Anti-Piracy Centre, a Finnish IP trade organization, which along with IFPI (which has RIAA/MPAA members) helped get a notable piracy site, the Pirate Bay, banned in Finland.

FACT, along with related IP groups, such as MPAA, BPI, and IFPI have also been instrumental in creating the site blocking structure of the UK. Although the UK has a stronger history, in comparison with the US, of censorship, the direction of censorship 
for the purpose of removing access based on copyright and other IP laws is heavily done through such entertainment trade associations. One noteworthy and recent example is the EU Court of Justice upholding the legality of member states being allowed to ban access to the website The Pirate Bay (Court of Justice of the EU, 2017). This was in response to a Dutch court ruling against the legality of banning the Pirate Bay. This was against MPAA affiliate BREIN (Foundation for the Protection of Copyright for the Entertainment Industry), who then brought it above Dutch law to the EU court. While the ability to have a transnational apparatus to counter state law is unique to the European Union, it is a common strategy of MPAA, and a central purpose to develop the numerous organizations and partnerships.

\section{Solutions}

As this trajectory of corporate power will likely become more complex and intertwined into new areas and industries, solutions to the problem of concentrated power will not simply be able to return to the antitrust laws and regulation that worked under the New Deal. Much of the means for the Majors and the MPAA to successfully lobby Washington to repeal the New Deal regulations had been based on how outdated these regulations had become. Constructed when theaters were the only exhibition sector of film, the Paramount Decree had not been properly adapted to the modern economy, with hyper-globalization, and new exhibition technologies emerging well beyond the capacity of existing regulatory frameworks. The need to update such regulations ran against both a growth in corporate lobbying and a greater reliance for Washington in promoting competitive American industries, especially as the permanency of the trade deficit became increasingly apparent. 


\section{Break up}

The clearest and most direct necessity to combat the varied and dispersed effects of such a consolidated industry would be to actualize antitrust laws. The issue around this is that while the Majors together constitute a clear oligopoly, with nearly $90 \%$ of box office market share in many countries, as six studios compete with one another, this still constitutes a "competitive" market according to contemporary antitrust norms. The primary issue is thus the varied forms of vertical monopolization and reach into other sectors. For the Studios this would simply be updating the Paramount Decree separating theater ownership from film producers to include all exhibition, including online streaming. This would mean other entrants to the market, such as Amazon and Netflix, would also not be able to produce content for their platforms. However, to fully actualize such antitrust regulation in today's digital environment, the limitations of existing regulation need to be mitigated. This will require prohibiting the monopolization of any sector as well as limiting the monopoly power and leverage of any one sector by utilizing tie-ins. ${ }^{53}$ As such, a host of tech giants, including Amazon and Google, would need to be dismantled.

For the studios this would mean dismantling the Mass Media Conglomerates, but also all elements of Mass Media. Not only does international distribution need to be delinked, limiting international releases to domestic distributors purchasing rights in that country, but all distribution needs to be delinked from production. This will limit the ability

\footnotetext{
${ }^{53}$ Thurman Arnold, one of the architects of antitrust regulation under FDR, had warned that the regulation did not go far enough to limit what he called "bottlenecks" that did not constitute monopolization, but could still be leveraged into other sectors. For the Studios, while exhibition was removed, distribution and production were still tied together, allowing them to regain their hold through internationalizing markets, production, and ultimately operating a flexible and financialized corporation.
} 
to assure markets for blockbusters through bloated budgets and large advertisement campaigns, and will result in a more competitive production market.

\section{Associations}

Trade associations themselves, as shown, perform a variety of roles beyond the simple collective representation. More problematic is the ability to join and partner with other numerous associations, including those that nearly represent an entire industry, such as the IIPA. These "peak" associations have allowed influence into the system not only in the common interest of its various members, but are themselves influenced by power dynamics from within the organization. Thus, expanding antitrust legislation, not only to the cartel-like activities of trade associations, but to associations of any kind will be essential to solve asymmetries of power. As stated, part of the entrenched power is that solutions will naturally cause problems that lead to more associational fixes. Should any corporate associations be allowed, they should necessarily be open to any business within the industry, thus diluting with membership beyond the shared interest and goals that a small number of corporate actors could organize around.

The united representation of corporations is even more problematic when compared to the lack of such institutions for other sectors of the economy, such as labor and consumers. For decades union membership and power has been declining. While corporations have merged, oligopolies have become the norm, and associations have expanded their membership, activities, and reach. The clear method to equalize power would be for stronger labor unions, in conjunction with eliminating the corporate unions, both as oligopolistic "megacorporations" and in the form of trade associations. With only $11 \%$ of employees in a union, the film industry has much room for improvement. Even so, where there are unions it is important that unions are fully independent of the corporations. As shown in chapter 3 and 4 , due to the mobility and transnationalism of 
film production, unions, especially for the above-the-line jobs, support subsidies and otherwise strengthening the oligopoly, so as to have access to their productions.

\section{Corporate State and Intellectual Property}

The most difficult task will be untangling the political and economic reliance many countries have on specific industries and "national champion" corporations. Especially for the United States, concerns of its perpetual trade deficit has given impetus to expanding antitrust liberalization and providing political and economic support for corporations that are still competitive globally. Outside of lobbying and personal relations in Washington, there is a proclaimed national interest in supporting transnational corporations that has been exacerbated since the 1980s under neoliberalism. Especially for film this conflation of national and corporate interest had been shaped by free trade and open markets (as opposed to "embedded liberalism" prior to neoliberalism) ${ }^{54}$ and the reliance on Intellectual Property Rights for high value-added industries. ${ }^{55}$ As such, the reliance on transnational corporations, the Major Studios, the MPAA and even the FACT associations can be seen as expressions of the "economic interest" of the U.S., much of it currently oriented toward China, which is one of the largest and fastest growing film markets, but which is also protected and weak in enforcing Intellectual Property Rights.

Despite some regional film production centers, the Hollywood Majors continue to be the only global distributors. Most major domestic producers fail to move far beyond their home market, and Bollywood and Nollywood are the only regional exceptions. While many large Asian markets, such as Japan and South Korea, follow similar in-

\footnotetext{
${ }^{54}$ See John Ruggie and Dani Rodrik.

55 See Sell (2003)
} 
between paths, possessing strong indie producers that have some reach in select foreign markets, but ultimately focus on the domestic market supplanting MPAA market share. The growth of the China market is the primary reason that Asia is not only the fastest growing film market, but is now the largest (See chart below). As the largest single foreign market as of 2016 at $\$ 6.6$ billion, China makes up nearly half of the entire Asian market of $\$ 14.9$ billion (2016 MPAA Theatrical Statistics).

\section{Box Office Size by Region}

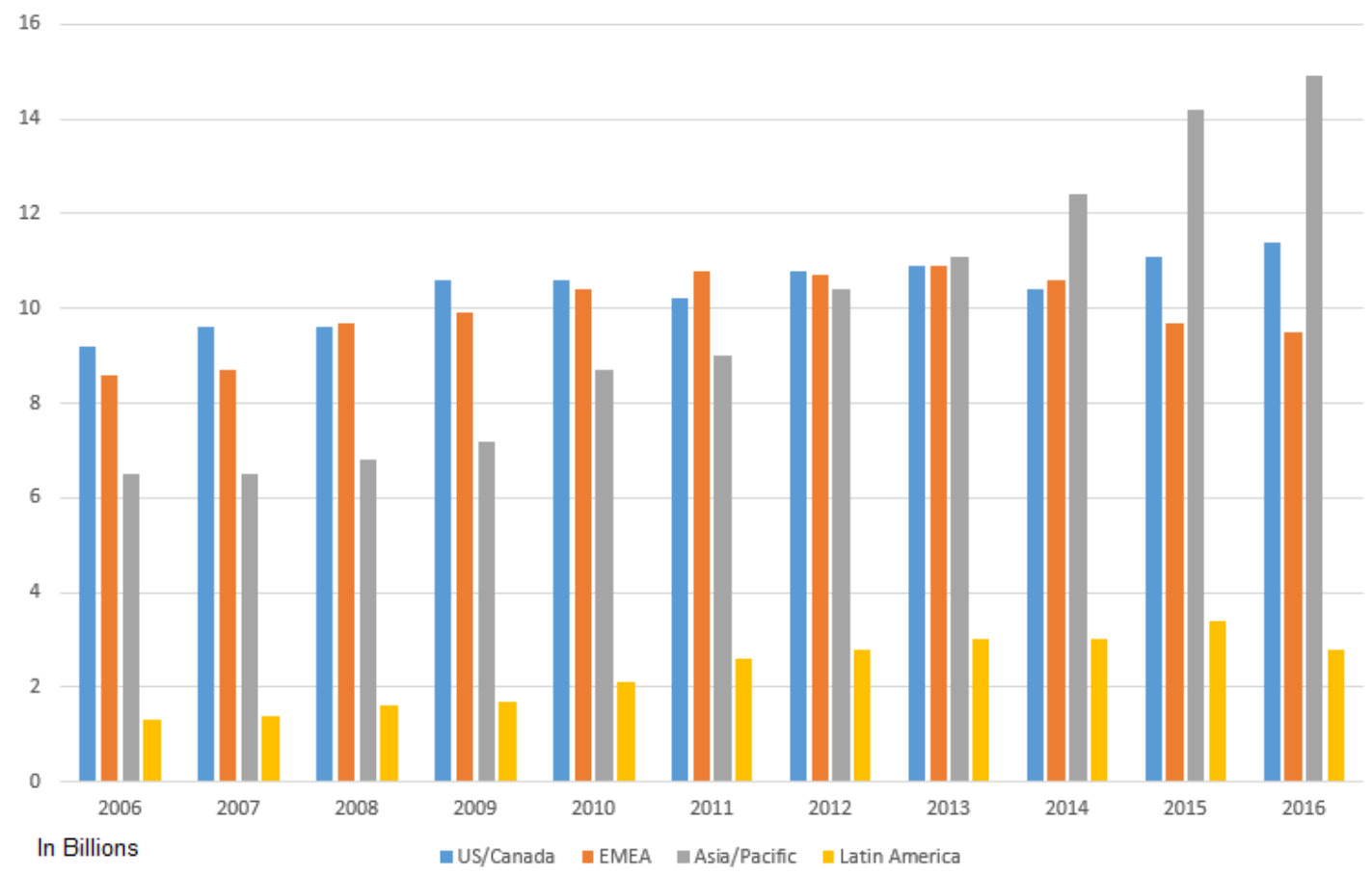

Source: MPAA Theatrical Market Statistics

Also, outside of the range of other specific contenders such as Nigeria and India, this makes Asia in general, and China in particular, as the obvious long-term targets for Major Studio's global market growth. Nonetheless, China, as the second largest economy and also second largest film market, has the potential to develop the next ollywood, either around Hong Kong or Beijing (or both). The regime, however, appears to be aware of this, with concerns that are economic and cultural, with a limit on 
American films entering Chinese theater at 34. On top of this, China has limited the percentage share that Majors are able to push onto theaters in China, and even then has allowed theaters to manipulate their numbers to pay out less to foreign studios, with the government even subsidizing theaters whose box office receipts are majority from domestic films (Dresden, 2017).

While this has been limiting the access and control of the Majors in the most important growing market, the larger issue has been centered around IP rights and tacitly accepted piracy within China. It has consistently been pushed by the MPAA that Chinese piracy is a large contributor to the US trade deficit, and that film is a leading trade commodity for the US, with four times higher exports than imports for the industry (Johnson, 2018). While this appears to be a relatively small issue, mostly affecting those directly within the industry, this, like all the other issues directed by the MPAA, has massive, long-term consequences. Corporations have increased their pressure campaigns and leverage to access the China market on their terms, both through attempting to use existing WTO channels to force Chinese compliance with IPR protections and the more recent support (among several corporate interest blocs) of the Trump Administration's more aggressive use of tariffs as leverage for the protection of intellectual property rights and liberalization of direct foreign investment in China (Lawson, 2018).

As such, the tariffs levied by the US against China, have, much as the principle of Special 301 itself, been unilateral punishments, over largely unresolved trade issues, such as subsidies and intellectual property--themselves rife with asymmetry and hypocrisy. As this work has shown, the Mass Media Conglomerates attained their global power partly through a global subsidy system that has provided a platform for their ongoing economic and political dominance, now joined by an even more integrated 
alliance of digital monopoly powerbrokers. The fact that these corporations want the Chinese government to allow this system to be extended to China is an indication of how global competition for market share easily overlaps with imperial rivalry. Therefore, the urgency of rolling back this entrenched system of corporate power has become more apparent as such unchecked power easily leads to imperialist conflict that may result in even graver consequences. As such, the transnational corporations demanding maximalist intellectual property protection from China, which means that that China is expected to follow rules ignored by the West, cannot be dismissed from the very corporate economic structure that led to globalization, neoliberalism, and the general widening and deepening of industrial consolidation, including film and media that affects so many elements of peoples' daily lives.

References

"2005 U.S. Theatrical Market Statistics". Motion Picture Association. Retrieved from https://www.immagic.com/eLibrary/ARCHIVES/GENERAL/MPAA US/M060309R .pdf

"2006 U.S. Theatrical Market Statistics". Motion Picture Association. Retrieved from http://pds4.egloos.com/pds/200708/28/11/2006-US-TheatricalMarket-Statistics-Report.pdf

" 2016 U.S. Theatrical Market Statistics". Motion Picture Association. Retrieved from https://www.motionpictures.org/wpcontent/uploads/2017/03/MPAA-Theatrical-Market-Statistics-2016 Final.pdf

Andy. (May 25, 2013). Five Undercover Police Cars Sent to Arrest Single Alleged Movie Pirate. Torrentfreak. Retrieved from https://torrentfreak.com/fiveundercover-police-cars-sent-to-arrest-single-alleged-movie-pirate-130525/

Arnold, Thurman W. The Bottlenecks of Business. Beard Books, 2000. 
Bakker, Gerben. (2003). Entertainment Industrialized: the emergence of the international film industry, 1890-1940. Cambridge University Press: New York

Balio, Tino. (1995). Grand design: Hollywood as a modern business enterprise, 1930-1939 (Vol. 5). Univ of California Press.

Bank, David, Nicholas Caplan, and Kristina Warmus. (September 13, 2013). Media Deep Dive: The Current State of the Film Studio Business. RCB Capital Markets.

Bank, David, Leo Kulp, Kutgun Maral, and Kristina Warmus. (October 23, 2014). TV Content: Traditional and Digital Syndication. RCB Capital Markets.

Baran, P., \& Sweezy, P. (1966). Monopoly capitalism. An Essay on the American Economic and Social Order. Monthly Review Press: New York

Bernstein, Irving, 1916-2001. The Economics of Television Film Production And Distribution: A Report to Screen Actors Guild. Sherman Oaks, Calif., 1960

Bishop-Henchman, Joseph. (September 29, 2016). "California LAO Finds $\$ 1$ of Every $\$ 3$ in Film Incentives Go to Projects that Would have Happened Anyway." Tax Foundation. Available online at:

https://taxfoundation.org/california-lao-finds-1-every-3-film-incentives-go-projectswould-have-happened-anyway/

Biskind, Peter. (1999). Easy Riders Raging Bulls: How the Sex-Drugs-And Rock'N Roll Generation Saved Hollywood. Simon and Schuster.

Blaney, Martin. (December 14, 2917). "Germany Box Office Report 2017: A Successful Year Powered by Local Comedy". Screendaily. Retrived from https://www.screendaily.com/box-office/germany-box-office-report-2017-asuccessful-year-powered-by-local-comedy-/5124978.article

Boedeker, Hal. (November 30, 2014). "What is the State of Film, TV Productions in Florida?." Orlando Sentinel. Available online at: http://www.orlandosentinel.com/business/os-film-tv-production-florida-20141124story.html

Boldrin, Michele and Levine, David K. (2008). Against Intellectual Monopoly. Cambridge University Press: New York, NY 
Bowman, Scott. (2010). Modern Corporation and American Political Thought: Law, Power, and Ideology. Penn State Press.

Boxofficemojo.com. Yearly Box Office 1980-2016. Retrieved from http://www.boxofficemojo.com/yearly/ Publishers.

Brady, Robert. (1943). Business as a System of Power. Transaction

Brady, Robert A. (November, 1947). The Problem of Monopoly. Annals of the American Academy of Political and Social Science, Vol. 254, pp. 125-136

Bruck, Connie. (2004). When Hollywood Had a King: The Reign of Lew Wasserman, Who Leveraged Talent into Power and Influence. Random House Incorporated.

Buder, Emily. (August 22, 2016). "The Best Countries in the World to Film Your Movie, Based on Production Incentives." No Film School. Available online at: https://nofilmschool.com/2016/07/film-production-incentives-tax-incentivesmovie-rebates

Christopherson, Susan and Storper, Michael. (1986). "The City as Studio, the World as Back-lot: The Impact of Vertical Disintegration on the Location of the Motion-Picture Industry." Environment and Planning D: Society and Space 4: $305-20$

Crafton, D. (1999). The talkies: American cinema's transition to sound, 1926-1931 (Vol. 4). Univ of California Press.

CFTPA/APFTQ. (2008). Profile 2008: An economic report on the Canadian film and television production industry. Ottawa: Canadian Film and Television Production Association/Association des Producteurs de Films et de Télévision du Québec and Department of Canadian Heritage

Cook, David (2000). Lost Illusions: American Cinema in the Shadow of Watergate and Vietnam, 1970-1979 (Vol. 9). Univ of California Press.

Cooke, P. (2007). "Supporting contemporary German film: How triumphant is the free market?." Journal of Contemporary European Studies, 15(1), 35-46.

Court of Justice of the European Union. (2017). Making available and managing an online platform for sharing copyright-protected works, such as 'The Pirate Bay', may constitute an infringement of copyright. Retrieved from https://curia.europa.eu/jcms/upload/docs/application/pdf/2017$\underline{\text { 06/cp170064en.pdf }}$ 
Cox, Ronald W.; Skidmore-Hess, Daniel, and Skidmore-Hess, Cathy. (2012). Conclusion: What now? Implications of the long turn to the right. In Ronald W. Cox(Ed.) Corporate Power and Globalization in US Foreign Policy. Routledge: New York

Davis, Charles H. and Kaye, Janice. 2010. "International Film and Television Production Outsourcing and the Development of Indigenous Capabilities: The Case of Canada." In G. Elmer et al., eds., Locating Migrating Media. Lanham, MD: Rowman and Littlefield.

Della Porta, Donatella. (2008). 11 Comparative analysis: case-oriented versus variable-oriented research. In Della Porta, D., \& Keating, M. (Eds.). Approaches and methodologies in the social sciences: A pluralist perspective. Cambridge University Press.

Deutsche Welle. (March 16, 2017). "German Government to Double Film Subsidies." Deutsche Welle. Available online at: http://www.dw.com/en/germangovernment-to-double-film-subsidies/a-37960001

Duménil, G., \& Lévy, D. (2011). The crisis of neoliberalism. Harvard University Press.

Epstein, Edward Jay. (April 25, 2005). "How to Finance a Hollywood Blockbuster: Start with German Subsidies." Slate. Available online at: http://www.slate.com/articles/arts/the hollywood economist/2005/04/how to fina nce a hollywood blockbuster.html

Epstein, Edward Jay. (2006). The big picture: Money and power in Hollywood. Random House Incorporated.

Epstein, Edward Jay. (2012). The Hollywood economist 2.0: The hidden financial reality behind the movies. Melville House.

Ernesto. (August 8, 2014). Domain Registrars Deny Police Requests to Suspend Pirate Sites. Torrentfreak. Retrieved from https://torrentfreak.com/domain-registrars-deny-police-requests-suspend-piratesites-140808/

Embassy Canberra. "FILM/TV INDUSTRY FILES COPYRIGHT CASE AGAINST AUSSIE ISP”. Wikileaks Cable: 08CANBERRA1197_a. Dated November 30, 2008. Retrieved from https://wikileaks.org/plusd/cables/08CANBERRA1197 a.html 
Etherington, Darrell. (November, 22, 2012). Finnish Police Seize 9-Year Old's Winnie The Pooh Laptop For Using The Pirate Bay. Tech Crunch. Retrived from https://techcrunch.com/2012/11/22/finnish-police-seize-9-year-olds-winniethe-pooh-laptop-for-using-the-pirate-bay/

Fergusson, lan F., Mark A. McMinimy, and Brock R. Williams. (2015) "The Trans-Pacific Partnership (TPP) negotiations and issues for congress.".

Film Florida. (August 2013). "Stakeholder Interview Briefing." Available online at: https://www.scribd.com/document/207191802/Film-FloridaStakeholder-Interview-Briefing-Report-by-Think-Spot-Prepared-for-Film-FloridaAugust-2013

Foster, John Bellamy. "Monopoly-finance capital." Monthly Review 58, no. 7 (2006): 1.

Fuchs, Doris. A. (2007). Business power in global governance. Boulder, CO: Lynne Rienner.

Galambos, Louis. (1966). Competition \& cooperation; the emergence of a national trade association.

Galperin, H. (1999). Cultural industries policy in regional trade agreements: the cases of NAFTA, the European Union and MERCOSUR. Media, Culture \& Society, 21(5), 627-648.

Gasher, Mike. (2002). Hollywood North: The Feature Film Industry in British Columbia. UBC Press. Vancouver.

George Alexander, L., and Bennett Andrew. (2005). Case studies and theory development in the social sciences. Mit Press.

Grece, Christian. (2016). "How do films circulate on VOD services and in cinemas in the European Union." Observatoire européen de l'audiovisuel

Hampp, Andrew. (October 18, 2010). "Can Paramount Scare up same Buzz for 'Paranormal' Sequel?". AdAge. Retrieved from https://adage.com/article/madisonvine-news/paramount-scare-buzz-paranormalsequel/146518/

Hanks, Douglas. (January, 29, 2014). "With Florida Film Incentives Drying up, Industry Worries about a Statewide 'Cut'!." Miami Herald. Available online at: http://www.miamiherald.com/latest-news/article1959720.html 
Press

Harvey, David. (2005). A brief history of neoliberalism. Oxford University

HR\&A Advisors, Inc. (2015). "Economic Impacts of the Louisiana Motion Picture Investor Tax Credit." Available online at: https://www.mpaa.org/wpcontent/uploads/2015/04/Economic-Impacts-of-the-Louisiana-Motion-PictureInvestor-Tax-Credit1.pdf

Holt, Jennifer. (2011). Empires of Entertainment: Media Industries and the Politics of Deregulation, 1980-1996. Rutgers University Press

Irwin, Janelle. (October 20, 2017). "Film Incentives Back on the Table in 2018." Tampa Bay Business Journal. Available online at:

https://www.bizjournals.com/tampabay/news/2017/10/20/film-incentives-back-onthe-table-in-2018.html

Jansen, Christian. (2005). "The Performance of German Motion Pictures, Profits, and Subsidies: Some Empirical Evidence." Journal of Cultural Economics. Vol. 29, No. 3, pp. 191-212

Jaivin, Linda. The Creativity \& Copyright Value Chain. Australian Federation Against Copyright Theft. Retrived from http://auscreenassociation.film/wp-content/uploads/2016/07/No-to-FairUse Aus hires.pdf

Johns, Adrian. (2009). Piracy: The Intellectual Property Wars from Gutenberg to Gates. University of Chicago Press: Chicago

Johnson, Ted. (June 17, 2015)." Georgia Crafts a Peachy Deal to Keep Productions Filming in the State." Variety. Available online at: http://variety.com/2015/artisans/production/georgia-deal-to-keep-productions-instate-1201521401/

Kanzler, Martin, and Simone, Patrizia. (2019) The Circulation of European Films outside of Europe: Key Figures 2017. European Audiovisual Observatory. Retrived from https://rm.coe.int/the-circulation-of-european-films-outside-europekey-figures-2017/168094629e

Kirshner, Jonathan. (2012). Hollywood's Last Golden Age: Politics, Society, and the Seventies Film in America. Cornell University Press.

Lee, Kevin. (2007-2008). "The Little State Department": Hollywood and the MPAA's Influence on US. Trade Relations. Northwestern Journal of International Law and Business. Vol. 28, No. 1, pp. 371-398 
Lev, Peter. (2003). Transforming the Screen, 1950-1959. University of California Press.

Lindsey, D. (2006) “The German New Wave.” Der Spiegel Online. Available online at:

http://service.spiegel.de/cache/international/0,1518,400156,00.html

Lynch, Robert. (1996). "Do State and Local Tax Incentives Work?". Economic Policy Institute. Washington, D.C.

Maddaus, Gene. (August 28, 2014). "Here are the Winners and Losers in California's $\$ 330$ Million Film Tax Subsidy." LA Weekly. Available online at: http://www.laweekly.com/news/here-are-the-winners-and-losers-in-californias330-million-film-tax-subsidy-5036475

May, Christopher. (2000). A Global Political Economy of Intellectual Property Rights: The New Enclosures? Routledge: New York, NY

McChesney, R. W. (2001). Global media, neoliberalism, and imperialism. MONTHLY REVIEW-NEW YORK-, 52(10), 1-19.

McDonald, Adrian. (2011). "Down the Rabbit Hole: The Madness of State Film Incentives as a "Solution" to Runaway Production." Journal of Business Law (University of Pennsylvania) 13(1): 101-181

McDonald, Adrian. (2011). "2016 Feature Film Study." Film L.A. Available online at: https://www.filmla.com/wpcontent/uploads/2017/05/2016 film study WEB.pdf

McDonald, Paul. (2015). Piracy and the Shadow History of Hollywood. In (eds. McDonald, Paul, Carman, Emily, Hoyt, Eric, and Drake, Philip) Hollywood and the Law. British Film Institute

McWhirter, Cameron and Schwartzel, Erich. (February 6, 2015). "Georgia's Booming Film Industry Produces Shortage of Crew Members." The Wall Street Journal. Available online at: https://www.wsj.com/articles/georgiasbooming-film-industry-produces-shortage-of-crew-members-1423242778

Miller, Toby, Nitin Govil, John McMurria, Richard Maxwell, and Ting Wang (2005) Global Hollywood 2. British Film Institute: London

Monaco, Paul. (2003) The Sixties: 1960-1969. University of California Press. 
The Moving Picture World (March 9, 1907). The World Photographic Publishing Company. Vol 1. No. 1.

"Number of U.S. Movies Screens". National Association of Theatre Owners. Retrieved from http://www.natoonline.org/data/us-movie-screens/

Peterson, Myles. (January 21, 2012). Australia: US Copyright Colony or Just a Good Friend?. Torrentfreak. Retrived from https://torrentfreak.com/australia-us-copyright-colony-or-just-a-good-friend$\underline{120121 /}$

Peukert, Christian, Jörg Claussen, and Tobias Kretschmer. (2017). "Piracy and box office movie revenues: Evidence from megaupload." International Journal of Industrial Organization 52 : 188-215.

Preston, Patrick. (2013). "If You Scale Back Now, you Probably Lose Everything": State Tax Incentives and the Motion Picture Industry." MEIEA Vol. 13, ISS. 1: 181-205

Prince, Stephen. (2000). A New Pot of Gold: Hollywood under the Electronic Rainbow, 1980-1989. University of California Press: Los Angeles, California

Puttnam, David. (1997) The Undeclared War: The Struggle for Control of the World's Film Industry. HarperCollinsPublishers: London

Rainey, James. (March 8, 2016). "The Perils of Promotion: Pricey TV Campaigns, Fear of Change Shackles Movie SPending. Variety. Retrived from https://variety.com/2016/film/features/movie-marketing-advertising-tv-campaigns1201724468/

Roxborough, Scott. (August, 5, 2019). "China is now the Number one International Market for European Fllms". The Hollywood Reporter. Retrived from https://www.hollywoodreporter.com/news/china-is-now-number-one-internationalmarket-european-films-1229147

Russo, G. (2007). Supermob: How Sidney Korshak and His Criminal Associates Became America's Hidden Power Brokers. Bloomsbury Publishing USA.

Russon, Mary-Ann. (May 24, 2016). Hollywood will no longer fun UK anti Film-Piracy Group FACT. International Business Times. Retrieved from http://www.ibtimes.co.uk/hollywood-will-no-longer-fund-uk-anti-film-piracy-groupfact-1561809 
Schatz, Thomas. (1999). Boom and bust: American cinema in the 1940s (Vol. 6). University of California Press.

Schmitter, Philippe C., and Jurgen R. Grote. (1997). "The corporatist sisyphus: past, present and future."

Scott, Allen. (2002). "A New Map of Hollywood: The Production and Distribution Of American Motion Pictures." Regional Studies 36, 957-75.

Scott, Allen. (2004). Hollywood and the world: the geography of motionpicture distribution and marketing. Review of international political economy, 11(1), 33-61.

Seabury, William Marston. (1926). The Public and the Motion Picture Industry. The Macmillan Company: New York

Sell, Susan K. (2003). Private Power, Public Law: The Globalization of Intellectual Property Rights. Cambridge University Press: New York

Shaffer, G. (2006). "What's new in EU trade dispute settlement? Judicialization, public-private networks and the WTO legal order." Journal of European Public Policy, 13(6), 832-850.

Shiu, Stephen K. (2006). Motion Picture Piracy: Controlling the Seemingly Endless Supply of Counterfeit Optical Discs in Taiwan. Vanderbilt Journal of Transnational Law. Vol. 39, pp. 607-643

Silver, Jonathan D. (2007). "Hollywood's dominance of the movie industry: how did it arise and how has it been maintained?." PhD diss., Queensland University of Technology

Spaner, David. (2012). Shot It!: Hollywood Inc. and the Rising of Independent Film. Arsenal Pulp Press: Vancouver, BC

Steinbock, Dan. (1995). Triumph and Erosion in the American Media and Entertainment Industries. Quorum Books: Westport, CT

Story, Louise; Fehr, Tiff, and Watkins, Derek. (2016). "United States of Subsidies." New York Times. Available online at: http://www.nytimes.com/interactive/2012/12/01/us/governmentincentives.html? $\mathrm{r}=0$ \#home

Taddeo, Annette. (2018). Florida Motion Picture Capital Corporation Bill Proposal. Available online at: http://www.flsenate.gov/Session/Bill/2018/1606/BillText/ /PDF 
Tannenwald, Robert. (2010). "State Film Subsidies: Not Much Band for Too Many Bucks." Center on Budget and Policy Priorities. Available online at: https://www.cbpp.org/research/state-film-subsidies-not-much-bang-for-too-many$\underline{\text { bucks }}$

Thom, Michael. (2016). "Lights, Camera, but no action? Tax and economic development lessons from state motion picture incentive programs." American Review of Public Administration.

Thom, Michael, and Brian An. (2017). "Fade to Black? Exploring Policy Enactment and Termination through the Rise and Fall of State Tax Incentives for the Motion Picture Industry."American Politics Research 45:85-108.

United States Trade Representative. (2005). 2005 Special 301 Report. Office of the United States Trade Representative. Retrieved from http://www.ustr.gov/archive/assets/Document Library/Reports Publications/2005 /2005 Special 301/asset upload file195 7636.pdf

United States Trade Representative. (2012). 2012 Special 301 Report. Office of the United States Trade Representative. Retrieved from

http://www.ustr.gov/sites/default/files/2012\%20Special\%20301\%20Re port $0 . p d f$

U.S. Bureau of Labor Statistics. Databases, Tables \& Calculators by Subject. Available online at:

https://data.bls.gov/timeseries/CES3133600101?amp\%253bdata tool=XGtable\& output view=data\&include graphs=true

U.S. Census Bureau. (February 10. 2015). "Motion Picture and Video Receipts Exceed $\$ 80$ Billion, According to Census Bureau." Available online at: https://www.census.gov/newsroom/press-releases/2015/cb15-25.html

Valenti, Jack. (2008). This Time, this Place: My Life in War, the White House, and Hollywood. Three Rivers Press.

Vogel, Harold L. (2014). Entertainment industry economics: A guide for financial analysis. Cambridge University Press

Wasko, Janet. (1994). Hollywood in the Information Age. First University of Texas Press:

Austin, TX 
Walser, Adam. (August 22, 2016). "Lack of Subsidies in Film Industry Driving Florida Jobs to Other States." ABC News. Available online at:

https://www.abcactionnews.com/news/local-news/i-team-investigates/lack-ofsubsidies-in-film-industry-driving-florida-jobs-to-other-states

Weatherford, Brian. (2016). "California's First Film Tax Credit Program." The Legislative Analyst's Office. Available online at: https://lao.ca.gov/reports/2016/3502/First-Film-Tax-Credit-Prog-092916.pdf

Wilcox, Ben and Krassner, Dan. (February 17, 2014). "Florida Film Incentives: "Action" or "Fade to Black"?." Integrity Florida. Available online at: http://files.ctctcdn.com/d9f43dd5201/e93e102e-8034-41bc-a8a0$\underline{\text { f2a3f3d5ab65.pdf }}$

Young, Alasdair R., \& Peterson, John. (2006). "The EU and the new trade politics." Journal of European Public Policy, 13(6), 795-814.

Zeller, C. (2007). From the gene to the globe: Extracting rents based on intellectual property monopolies. Review of International Political Economy, 15(1), 86-115. 
VITA

MICHAEL WARTENBE

44602 Pinebreeze blvd

Callahan, FL 32011

(904) 507-1902

mwart001@fiu.edu

Education and Experience

Present - Florida International University

PhD Candidate

2014 - Florida International University

M.A. International Relations

2010 - Florida State University

M.S. International Affairs

2009 - University of Central Florida

B.A. Political Science-International Relations

2006 - Florida Community College of Jacksonville

A.A

2010 - 100 hour, Teaching English as a Foreign Language

2010 - Holocaust Institute for Educators

Adjunct Professor: International Political Economy, Politics of the European Union, Comparative Political Economy

Teaching Assistant: U.S. Foreign Policy

International Political Economy

Introduction to International Relations

International Relations of Latin America

The Presidency

The Legislative Process

Sex, Power and Politics

Ancient and Medieval Political Theory

International Relations of the Middle East 
"Global Supply Chains and the Politics of the High-Tech Revolution," with Ronald Cox, in The Political Economy of Robots, ed. Ryan Kiggins, Palgrave Macmillan 2016.

"Corporations, Associations and the State: The International Subsidy System for Film." Class, Race and Corporate Power 7, no. 2 (2019): 6.

"Transition of Hegemonies: The Soviet Union to the Transnational Capitalist Class", Florida Political Science Association Annual Meeting, April 2nd, 2016, Lakeland, FL

"The Organized Political Economy: Power and Collusion in Trade Associations and Class" ISA Annual Conference, March 16th-19th, 2016, Atlanta, GA

"Power and Collusion in Trade Associations: The Motion Picture Association of America", International Studies Association South, Tampa, October 23-24, 2015

"How Neoliberalism is New: Ideology and Instrumental State", Florida Political Science Association Annual Meeting, University of Central Florida, March 28, 2015

"The Neoliberalization of the Motion Picture Industry", International Studies Association Annual Convention, New Orleans, February 18-21, 2015

"The MPAA Cartel, the Government, and the World Market", New York State Political Science Association Conference, St. John's University, April 25-26, 2014

"The MPAA Cartel, the Government, and the World Market", Florida Political Science Association Annual Meeting, Flagler College, March 8, 2014

"The European Central Bank and Peripheral States in the Eurozone", Annual Conference on International Political Economy, Gediz University, Izmir, May 23-25, 2012 